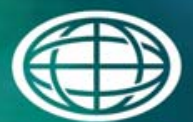

Savannah River

National Laboratory ${ }^{m}$

OPERATED BY SAVANNAH RIVER NUCLEAR SOLUTIONS

\title{
Laboratory Evaporation Testing of Hanford Waste Treatment Plant Low Activity Waste Off-Gas Condensate Simulant
}

\author{
Duane J. Adamson \\ Charles A. Nash \\ Daniel J. McCabe \\ Charles L. Crawford \\ William R. Wilmarth \\ January, 2014 \\ SRNL-STI-2013-00713
}




\section{DISCLAIMER}

This work was prepared under an agreement with and funded by the U.S. Government. Neither the U.S. Government or its employees, nor any of its contractors, subcontractors or their employees, makes any express or implied:

1. warranty or assumes any legal liability for the accuracy, completeness, or for the use or results of such use of any information, product, or process disclosed; or

2. representation that such use or results of such use would not infringe privately owned rights; or

3. endorsement or recommendation of any specifically identified commercial product, process, or service.

Any views and opinions of authors expressed in this work do not necessarily state or reflect those of the United States Government, or its contractors, or subcontractors.

\section{Printed in the United States of America \\ Prepared for U.S. Department of Energy}


Keywords: Evaporation

Technetium

Retention: Permanent

\title{
Laboratory Evaporation of Hanford Waste Treatment Plant Low Activity Waste Off-Gas Condensate Simulant
}

\author{
Duane J. Adamson \\ Charles A. Nash \\ Daniel J. McCabe \\ Charles L. Crawford \\ William R. Wilmarth
}

January, 2014

Prepared for the U.S. Department of Energy under contract number DE-AC09-08SR22470. 


\section{AUTHORS:}

\section{REVIEWS AND APPROVALS}

Duane J. Adamson, Process Technology Programs

Date

Charles A. Nash, Advanced Characterization and Process Research

Date

Daniel J. McCabe, Advanced Characterization and Process Research

Date

Charles L. Crawford, Process Technology Programs

Date

William R. Wilmarth, Environmental \& Chemical Process Research Programs Date

TECHNICAL REVIEW:

Scott H. Reboul, Advanced Characterization and Process Research

Date

APPROVAL:

F. M. Pennebaker, Manager

Date

Advanced Characterization and Process Research

C.C. Herman, Hanford Programs Manager

Date

Environmental \& Chemical Process Technology Research Programs

S. L. Marra, Manager

Date

Environmental \& Chemical Process Technology Research Programs 
Revision 0

\section{ACKNOWLEDGEMENTS}

Thanks to summer intern Megan Morse for her assistance in initial preparation of the simulant formulation for this work. Thanks to technicians Jonathan Duvall and David (Andy) Foreman for set up and performing many activities during the evaporation campaigns. 


\section{EXECUTIVE SUMMARY}

The Hanford Waste Treatment and Immobilization Plant (WTP) Low Activity Waste (LAW) vitrification facility will generate an aqueous condensate recycle stream, LAW Off-Gas Condensate, from the off-gas system. The baseline plan for disposition of this stream is to send it to the WTP Pretreatment Facility, where it will be blended with LAW, concentrated by evaporation and recycled to the LAW vitrification facility again. Alternate disposition of this stream would eliminate recycling of problematic components, and would enable de-coupled operation of the LAW melter and the Pretreatment Facilities. Eliminating this stream from recycling within WTP would also decrease the LAW vitrification mission duration and quantity of canistered glass waste forms.

This LAW Off-Gas Condensate stream contains components that are volatile at melter temperatures and are problematic for the glass waste form. Because this stream recycles within WTP, these components accumulate in the Condensate stream, exacerbating their impact on the number of LAW glass containers that must be produced. Approximately $32 \%$ of the sodium in Supplemental LAW comes from glass formers used to make the extra glass to dilute the halides to be within acceptable concentration ranges in the LAW glass. Diverting the stream reduces the halides in the recycled Condensate and is a key outcome of this work. Additionally, under possible scenarios where the LAW vitrification facility commences operation prior to the WTP Pretreatment facility, identifying a disposition path becomes vitally important. This task examines the impact of potential future disposition of this stream in the Hanford tank farms, and investigates auxiliary evaporation to enable another disposition path. Unless an auxiliary evaporator is used, returning the stream to the tank farms would require evaporation in the 242-A evaporator. This stream is expected to be unusual because it will be very high in corrosive species that are volatile in the melter (chloride, fluoride, sulfur), will have high ammonia, and will contain carryover particulates of glass-former chemicals. These species have potential to cause corrosion of tanks and equipment, precipitation of solids, release of ammonia gas vapors, and scale in the tank farm evaporator. Routing this stream to the tank farms does not permanently divert it from recycling into the WTP, only temporarily stores it prior to reprocessing. Testing is normally performed to demonstrate acceptable conditions and limits for these compounds in wastes sent to the tank farms. The primary parameter of this phase of the test program was measuring the formation of solids during evaporation in order to assess the compatibility of the stream with the evaporator and transfer and storage equipment.

The origin of this LAW Off-Gas Condensate stream will be the liquids from the Submerged Bed Scrubber (SBS) and the Wet Electrostatic Precipitator (WESP) from the LAW facility melter offgas system. The stream is expected to be a dilute salt solution with near neutral $\mathrm{pH}$, and will likely contain some insoluble solids from melter carryover. The soluble components are expected to be mostly sodium and ammonium salts of nitrate, chloride, and fluoride. This stream has not been generated yet, and, thus, the composition will not be available until the WTP begins operation, but a simulant has been produced based on models, calculations, and comparison with pilot-scale tests. This report discusses results of evaporation testing of the simulant. Two conditions were tested, one with the simulant at near neutral $\mathrm{pH}$, and a second at alkaline $\mathrm{pH}$. The neutral $\mathrm{pH}$ test is comparable to the conditions in the Hanford Effluent Treatment Facility (ETF) evaporator, although that evaporator operates at near atmospheric pressure and tests were 
done under vacuum. For the alkaline test, the target $\mathrm{pH}$ was based on the tank farm corrosion control program requirements, and the test protocol and equipment was comparable to that used for routine evaluation of feed compatibility studies for the 242-A evaporator.

One of the radionuclides that is volatile in the melter and expected to be in high concentration in this LAW Off-Gas Condensate stream is Technetium-99 $\left({ }^{99} \mathrm{Tc}\right)$. Technetium will not be removed from the aqueous waste in the Hanford WTP, and will primarily end up immobilized in the LAW glass by repeated recycle of the off-gas condensate into the LAW melter. Other radionuclides that are also expected to be in appreciable concentrations in the LAW Off-Gas Condensate are ${ }^{129} \mathrm{I},{ }^{90} \mathrm{Sr},{ }^{137} \mathrm{Cs}$, and ${ }^{241} \mathrm{Am}$. The concentrations of these radionuclides in this stream will be much lower than in the LAW, but they will still be higher than limits for some of the other disposition pathways currently available. At this time, these scoping tests did not evaluate the partitioning of the radionuclides to the evaporator condensate, since ample data are available separately from other experience in the DOE complex.

Results from the evaporation testing show that the neutral SBS simulant first forms turbidity at $\sim 7.5 \mathrm{X}$ concentration, while the alkaline-adjusted simulant became turbid at $\sim 3 \mathrm{X}$ concentration. The major solid in both cases was Kogarkoite, $\mathrm{Na}_{3} \mathrm{FSO}_{4}$. Sodium and lithium fluorides were also detected. Minimal solids were formed in the evaporator bottoms until a substantial fraction of liquid was removed, indicating that evaporation could minimize storage volume issues. Achievable concentration factors without significant insoluble solids were $17 \mathrm{X}$ at alkaline $\mathrm{pH}$, and $23 \mathrm{X}$ at neutral $\mathrm{pH}$. In both runs, significant ammonia carried over and was captured in the condenser with the water condensate. Results also indicate that with low insoluble solids formation in the initial testing at neutral $\mathrm{pH}$, the use of Reverse Osmosis is a potential alternate method for concentrating the solution, although an evaluation is needed to identify equipment that can tolerate insoluble solids. Most of the ammonia remains in the evaporator bottoms during the neutral $\mathrm{pH}$ evaporation, but partitions to the condensate during alkaline evaporation. Disposition of both streams needs to consider the management of ammonia vapor and its release.

Since this is an initial phase of testing, additional tasks related to evaporation methods are expected to be identified for development. These tasks likely include evaluation and testing of composition variability testing and evaluations, corrosion and erosion testing, slurry storage and immobilization investigations, and evaporator condensate disposition. 


\section{TABLE OF CONTENTS}

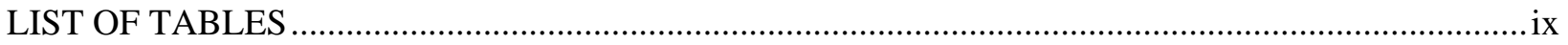

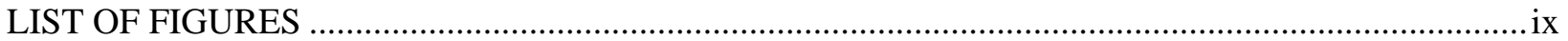

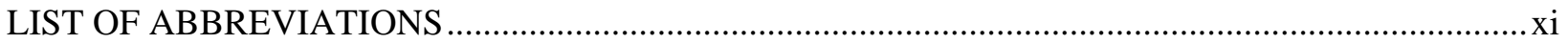

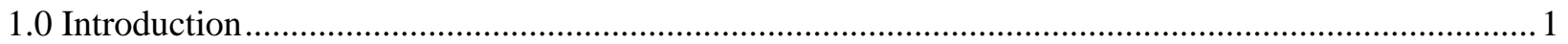

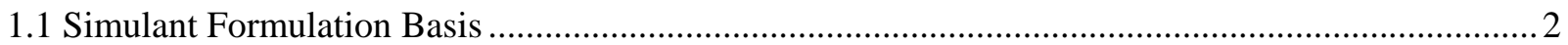

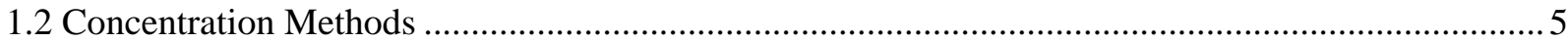

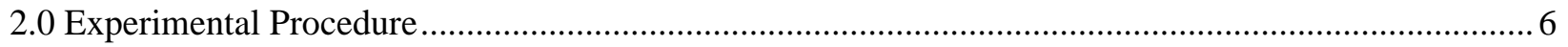

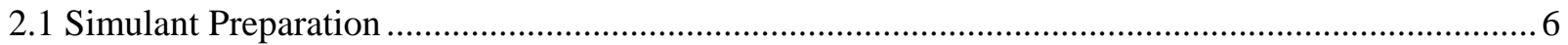

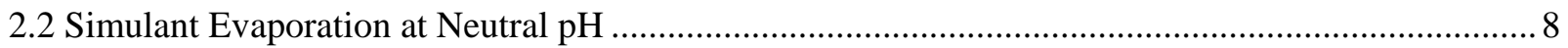

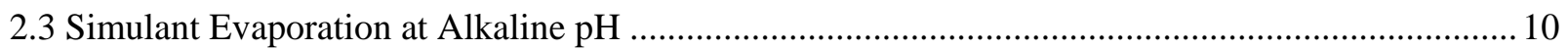

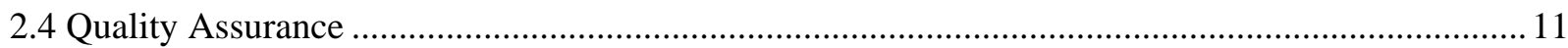

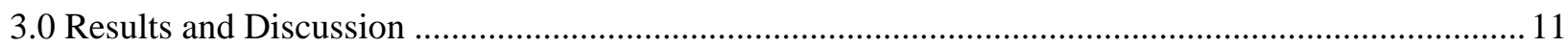

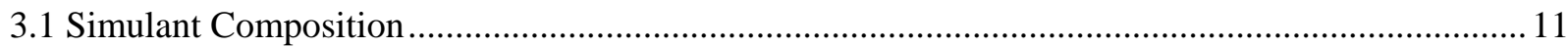

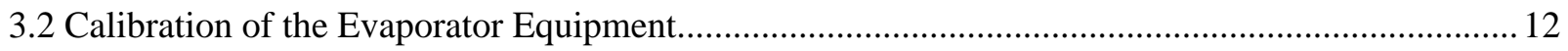

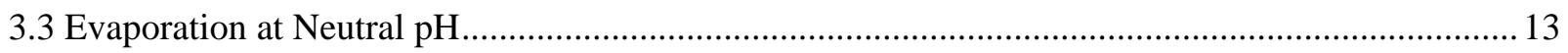

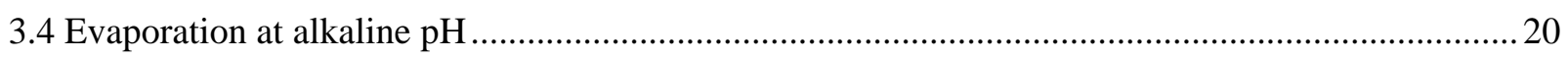

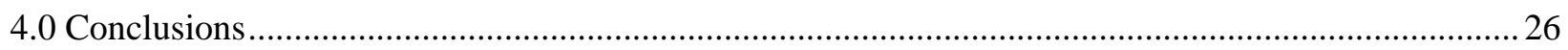

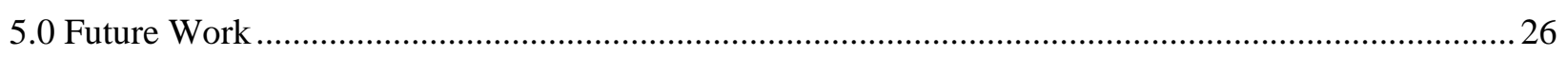

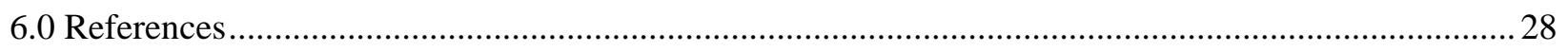

Appendix A . SVF-2732 Case 1 Mission Averaged Composition; First LAW and Second LAW .......A-1 Appendix B - Evaporator Pot Sample Analysis Results ......................................................................... B-1 


\section{LIST OF TABLES}

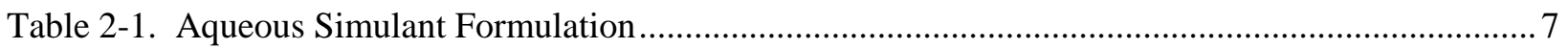

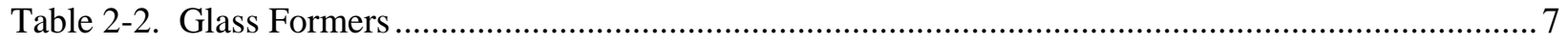

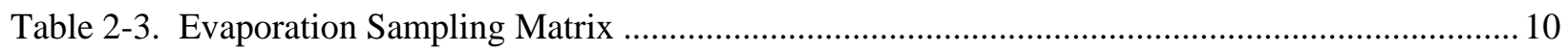

Table 2-4. Named vs. Actual Pot Sample Concentrations .................................................................. 10

Table 3-1. Neutralized Simulant Filtrate Chemical Composition............................................................ 12

Table 3-2 Calculated Quantity of Insoluble Species; Neutral Campaign ...............................................20

Table 3-3 Calculated Quantity of Insoluble Species; Alkaline Campaign..............................................25

\section{LIST OF FIGURES}

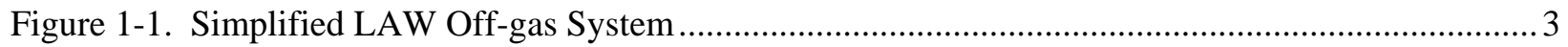

Figure 1-2. Schematic of Disposition of LAW Off-Gas Condensate to Tank Farms ............................... 4

Figure 1-3. Schematic of Alternative Concentration of LAW Off-Gas Condensate ................................. 4

Figure 2-1. Evaporator Apparatus Diagram...................................................................................... 8

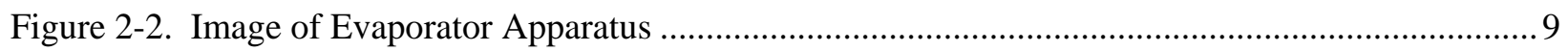

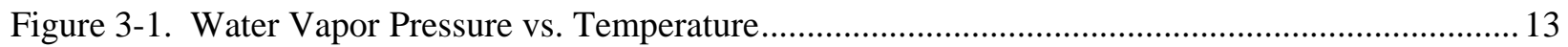

Figure 3-2. Evaporator Pressure and Temperature; $2^{\text {nd }}$ Day; Neutral Campaign...................................... 14

Figure 3-3 Image of Evaporator Pot at 30X Concentration; Neutral Campaign...................................... 15

Figure 3-4. Soluble Element Concentration Ratios vs. Concentration, Neutral Campaign ....................... 16

Figure 3-5. Soluble Anion Concentration Ratios vs. Concentration, Neutral Campaign ..........................17

Figure 3-6. X-Ray Diffraction Data from 30X Sample, Neutral Campaign .......................................... 17

Figure 3-7. Pot Sample Density versus Concentration Factor ................................................................ 18

Figure 3-8. Condensate Ammonia Concentration versus Total Condensate volume, Both Campaigns .... 19

Figure 3-9 Image of Evaporator Pot Samples; Neutral Campaign ........................................................20

Figure 3-10. Evaporator Pressure and Temperature; $2^{\text {nd }}$ Day, Alkaline Campaign ..................................2 21

Figure 3-11 Image of Evaporator Pot at 7.5X, Alkaline Campaign........................................................ 22

Figure 3-12. Soluble Element Concentration Ratios vs. Concentration, Alkaline Campaign ...................23 
Figure 3-13. Soluble Anion Concentration Ratios vs. Concentration, Alkaline Campaign....................... 23

Figure 3-14. X-Ray Diffraction Data from 24X Sample, Alkaline Campaign ........................................24

Figure 3-15 Image of Evaporator Pot Samples, Alkaline Campaign......................................................25 


\section{LIST OF ABBREVIATIONS}

$\begin{array}{ll}\text { Ci } & \text { Curie } \\ \text { DF } & \text { Decontamination Factor } \\ \text { DI } & \text { Deionized (water) } \\ \text { DOE } & \text { Department of Energy } \\ \text { DST } & \text { Double Shell Tank (HLW storage) } \\ \text { ETF } & \text { Effluent Treatment Facility } \\ \text { HLW } & \text { High Level Waste } \\ \text { HTWOS } & \text { Hanford Tank Waste Operations Simulator } \\ \text { IDF } & \text { Integrated Disposal Facility } \\ \text { ILAW } & \text { Immobilized Low Activity Waste } \\ \text { kPa } & \text { kiloPascals (absolute pressure) } \\ \text { L } & \text { Liter } \\ \text { LAW } & \text { Low Activity Waste } \\ \text { LERF } & \text { Liquid Effluent Retention Facility } \\ \text { ORP } & \text { Office of River Protection (DOE) } \\ \text { PA } & \text { Performance Assessment } \\ \text { RO } & \text { Reverse Osmosis } \\ \text { SBS } & \text { Submerged Bed Scrubber } \\ \text { SRNL } & \text { Savannah River National Laboratory } \\ \text { WESP } & \text { Wet Electrostatic Precipitator } \\ \text { WSU } & \text { Waste Solidification Unit (at ETF) } \\ \text { WTP } & \text { Hanford Tank Waste Treatment and Immobilization Plant }\end{array}$




\subsection{Introduction}

Tank waste at the Hanford site will be treated in the WTP Pretreatment facility, and the decontaminated aqueous stream will be vitrified in the LAW facility. The Hanford LAW OffGas Condensate stream will be generated in the WTP by condensation and scrubbing of the LAW melter off-gas system by a SBS and WESP, as shown in Figure 1-1. This stream, which will contain substantial amounts of chloride, fluoride, ammonia, and sulfate ions and small amounts of radionuclides, will get recycled within the WTP process by return to the Pretreatment Facility where it will be combined with LAW and evaporated. Although the SBS and WESP streams can be separately routed to different points in the WTP, they are combined for purposes of this study since they ultimately re-combine at some point within the process. The halide and sulfate components both volatile in the melter and are only marginally soluble in glass, and often dictate the waste loading and thereby impact the waste glass volume. Additionally, long-lived ${ }^{99}$ Tc and ${ }^{129}$ I are volatile radionuclides that accumulate in the LAW system, and are challenging to incorporate in glass under the Hanford LAW melter operating conditions. Because ${ }^{99}$ Tc has a very long half-life and is highly mobile, it is the largest dose contributor to the Performance Assessment (PA) of the Integrated Disposal Facility (IDF) [Mann, 2003]. Diverting this LAW Off-Gas Condensate stream to an alternate disposal path (as indicated by a dashed diversion line on Figure 1-1) would have substantial beneficial impacts on the cost, life cycle, and operational complexity of WTP. "Much of the load for the Supplemental LAW Facility is caused by internal recycles - namely the halides (chlorine and fluorine) and to a lesser extent sulfur (mostly as sulfates). The halide concentrations can be so high that extra LAW glass needs to be made to accommodate the halides in the glass. Approximately $32 \%$ of the sodium in the supplemental $L A W$ product comes from glass formers used to make the extra glass to dilute halides down to tolerable concentrations." [Arakali, 2012].

The objective of this evaporation development task is to evaluate concentration options for disposition of the Hanford LAW Off-Gas Condensate stream in the Tank Farms (Figures 1-2 and 1-3) or by other evaporation or concentration steps. Treating this stream outside the WTP Pretreatment facility would allow commencement of the LAW facility operations prior to operation of the Pretreatment facility. Evaporation and disposal in another facility would divert the components out of WTP and gain the benefit of reduced LAW canistered glass volume. Recycle to the Tank Farms would not divert this stream from the LAW melter, only temporarily store it before reprocessing through WTP, but is a potential interim solution. This task is an initial scoping study, based on information and model scenarios available at this time. Many scenarios of treatment options and waste retrieval sequences can be envisioned which would have different Off-Gas Condensate compositions and facility impacts. This work begins the process of providing test results that can be used to guide decision-making, with additional testing expected in the future once plans and scenarios are finalized.

The overall plan for technology development of the concentration option, and other options for disposal has been documented [McCabe, 2013]. Other alternative disposal paths are being investigated, including treatment options. 


\subsection{Simulant Formulation Basis}

Because this stream is not yet being produced, and thus is not available for characterization, the simulant formulation was based on input from two sources. The projected solution chemistry and radionuclide content were based on version 7.4 of the Hanford Tank Waste Operations Simulator (HTWOS) modeling of the flow sheet [Belsher, 2012], performed by WRPS [SVF2732]. Insoluble solids composition was primarily based on analysis of LAW Off-Gas Condensate obtained from pilot-scale simulant melter testing [Matlack, 2006]. Basing the solution chemistry and radionuclide content on the computer modeling rather than melter testing results extends the range of compositions and allowed evaluation of process conditions for treatment of all tank wastes. This approach also accounts for internal WTP process streams, making it more comprehensive. However, since the computer model does not account for carryover of solids by physical entrainment, the insoluble solids were based on results from pilot-scale melter off-gas system testing. Since the pilot-scale testing showed species in the LAW Off-Gas Condensate stream that were essentially absent in the original LAW feed (e.g. Fe, $\mathrm{Si}, \mathrm{B}$ ), it is evident that some glass formers are carried overhead, partially dissolving in the aqueous stream. This step was replicated in the laboratory by adding glass formers to the aqueous sample to examine dissolution behavior and insoluble solids behavior. For this phase of the program, the insoluble solids were created using glass formers used for the LAW melter system in the mission average mass ratio [Arakali, 2012, Table 2-17], with the mass sum based on composition analysis results from testing on the DM1200 melter at Vitreous State Laboratory [Matlack, 2006]. Since boron is essentially absent from LAW, and is highly soluble and easy to analyze, it was selected as the benchmark species for the quantity of glass formers. Using boron was conservative because it is also more volatile than most other glass formers, and therefore preferentially partitioned to the condensate stream that was used as the benchmarking basis. Further, the composition was evaluated using chemical thermodynamic modeling software to determine potential precipitation of insoluble solids, acid neutralization, and dissolution of glassformer solids. Laboratory testing and analysis dictated the final, actual composition.

The HTWOS model run scenario selected as the basis for the solution chemistry was full operation of all of the WTP facilities, including both first and second LAW melters, albeit with diversion of the LAW Off-Gas Condensate streams from the LAW melter facilities (see dashed line indicating the diverted stream in Figure 1-1). This diversion has the effect of lowering the concentration of volatile problematic species (versus the condition where it is recycled and concentrations escalate), but is more realistic of the condition that would be encountered if the stream is diverted from WTP. This test program is an initial scoping phase, and further optimization and compositional ranges will be examined later. 
SRNL-STI-2013-00713

Revision 0

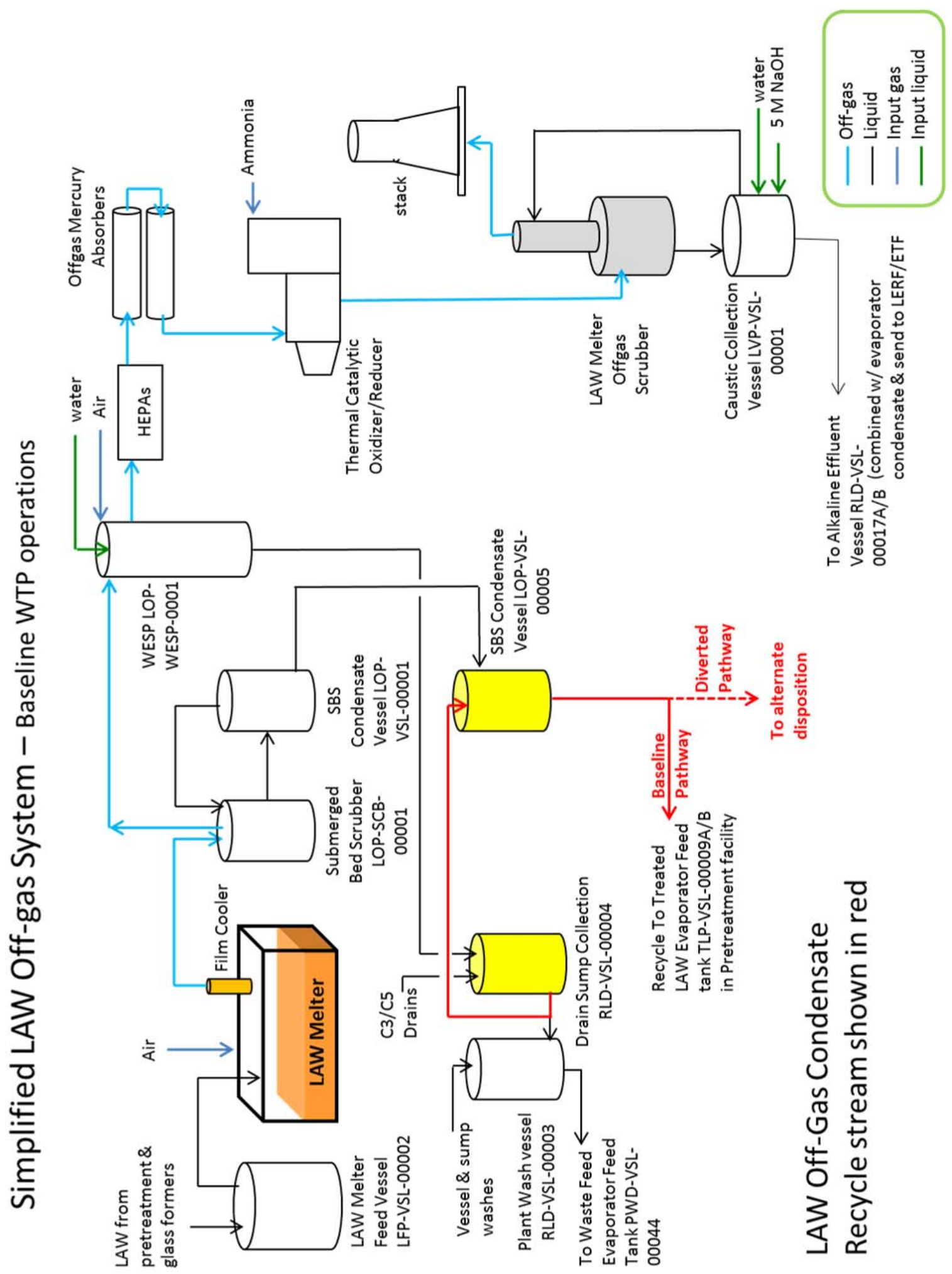

Figure 1-1. Simplified LAW Off-gas System

(adapted from 24590-WTP-RPT-PT-02-005, Rev. 6); (yellow indicates SBS/WESP LAW OffGas Condensate collection tanks, red lines indicate off-gas condensate pathway) 


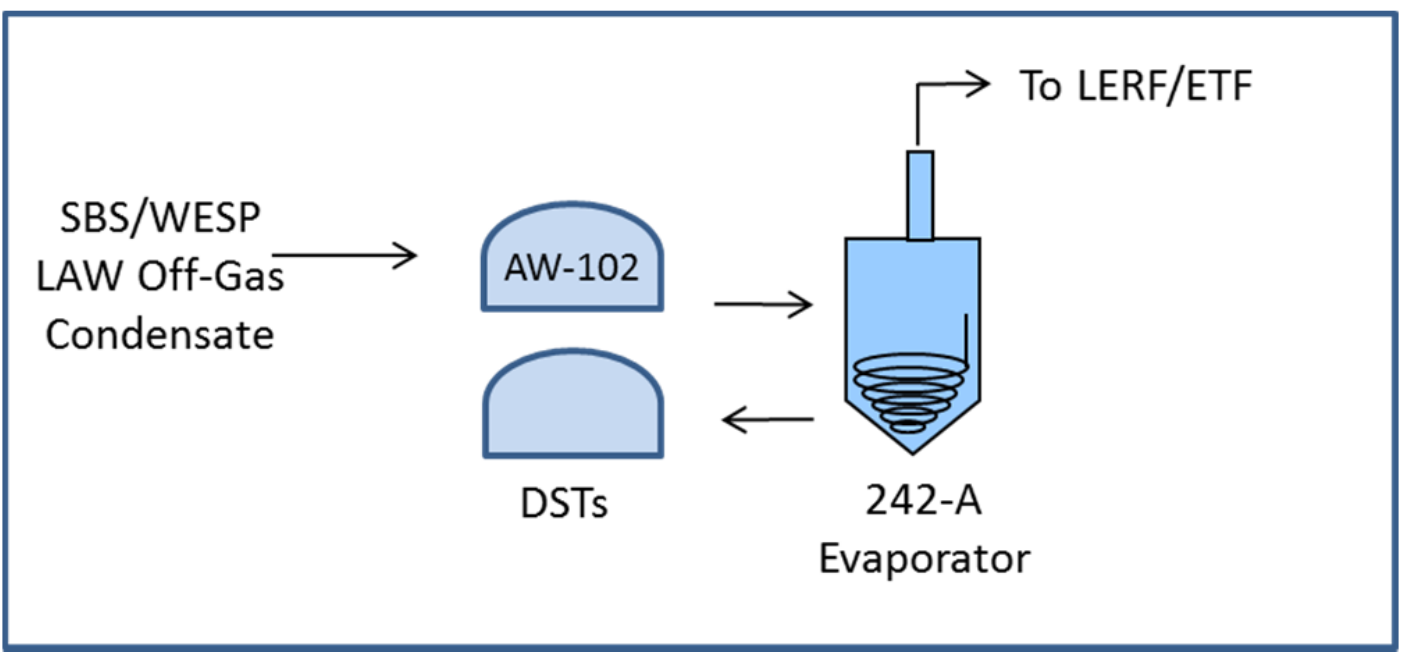

Figure 1-2. Schematic of Disposition of LAW Off-Gas Condensate to Tank Farms

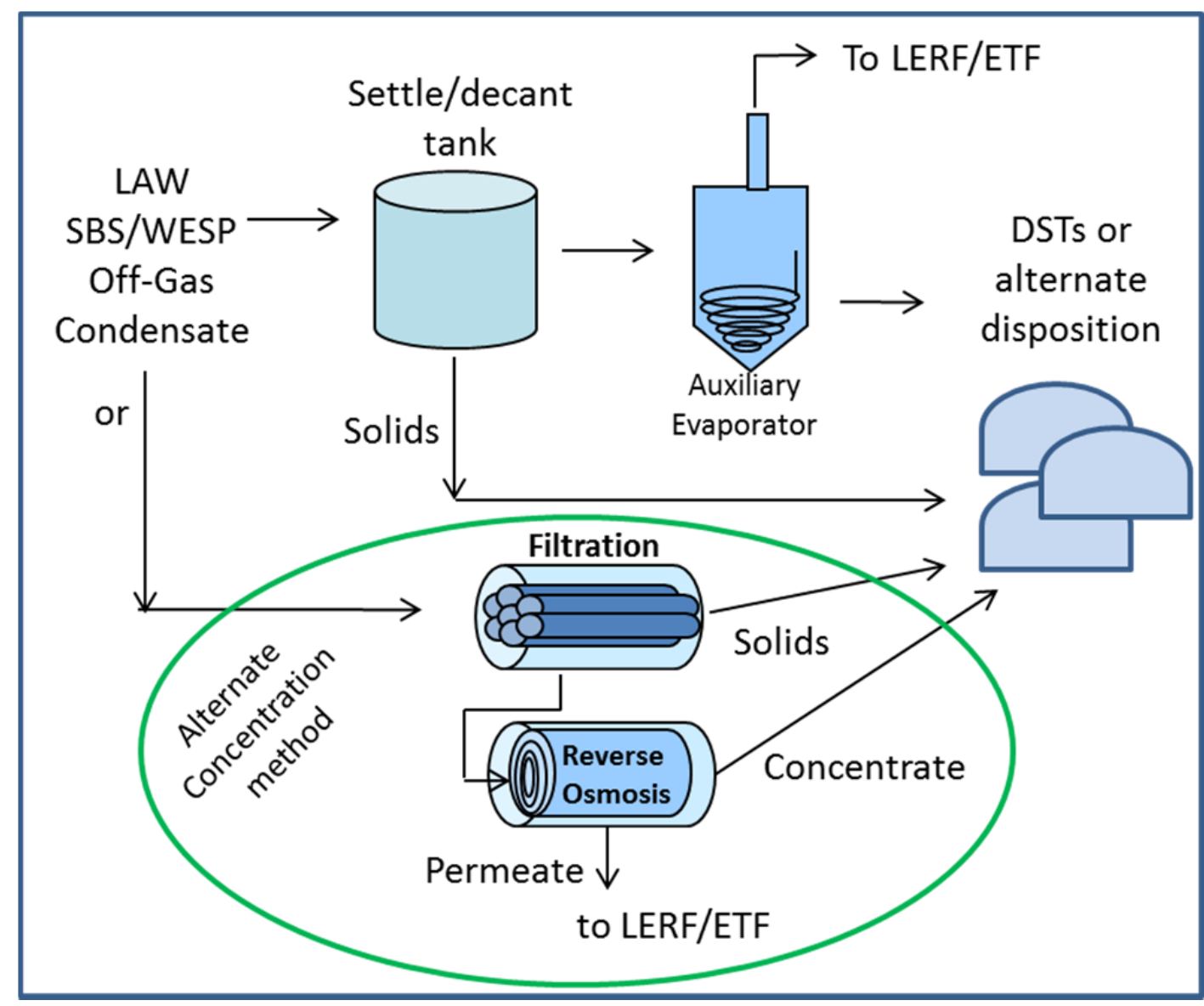

Figure 1-3. Schematic of Alternative Concentration of LAW Off-Gas Condensate 


\subsection{Concentration Methods}

If the LAW Facility starts up before the WTP Pretreatment facility, concentration of this waste stream may be needed to accommodate its storage in the Tank Farms [Crawford, 2008]. This is because the WTP will produce more aqueous waste volume than it treats, albeit with much lower activity and ionic strength, and there may be insufficient storage capacity for it, depending on several factors. The concentration method tested was evaporation, although the results can also aid in evaluating the feasibility of reverse osmosis (RO) by examining propensity for solids formation.

Using an evaporator for this concentration step has been discussed [Crawford, 2008, Yanochko, 2012]. For this study, it is assumed that evaporation in the 242-A evaporator would require first sending the Off-Gas Condensate to the Double Shell Tank (DST) system for storage, whereas, using an alternate evaporator would not require interim storage, but may require transfer of the evaporator bottoms to a DST. In either case, prior to transferring any stream into a Double Shell Tank (DST) in the Hanford tank farms, it is expected that caustic and nitrite will be added to comply with tank corrosion chemistry requirements. Evaporator testing examined these two scenarios: (1) where the LAW Off-Gas Condensate, including insoluble solids, is first adjusted for corrosion control and then stored prior to evaporation; and (2) where the LAW Off-Gas Condensate is decanted or filtered from the insoluble solids, and evaporated at neutral $\mathrm{pH}$. These scenarios are consistent with anticipated conditions for evaporation in 242-A and an auxiliary evaporator, respectively. The latter condition is also consistent with evaporator operation in the Effluent Treatment Facility (ETF), if the stream could be sent there.

Additional corrosion control limits may ultimately be imposed on this waste stream because of the high halide and sulfate content. Examination of the adequacy of current corrosion limits for disposition of this unique waste stream in the tank farms will be performed in the next phase of this program, if this is identified as the preferred disposition path. Regardless of the corrosion concerns, the unusual chemistry of this Off-Gas Condensate stream may cause formation of intractable solids when blended with some tank wastes. The concentration of this stream by evaporation raises the potential for intractable solids formation due to the silicon from glass formers in the LAW Off-Gas Condensate stream. This has been observed at SRS, where the High Level Waste Off-Gas Condensate stream formed aluminosilicates in the evaporator [Wilmarth, 2003]. However, the potential for aluminosilicate formation in the 242-A evaporator is lower than at SRS due to the much lower operating temperature of the vacuum evaporator.

Testing for evaporation in this phase was focused on solids formation and foaming. Evaporation of the LAW Off-Gas Condensate simulant in this phase was performed with standard laboratory equipment using two versions of the simulant; one pre-adjusted for corrosion control, and one not adjusted. The apparatus and test procedure were comparable to that used in the 222-S laboratory at Hanford [Callaway, 2010]. Both simulants were pre-contacted with the insoluble solids simulant generated from glass formers, and then filtered prior to evaporation. The simulant was evaporated, and subsamples were periodically collected and allowed to cool to room temperature to examine for insoluble solids formation and characterization. Any substantial amounts of insoluble solids formed were isolated and analyzed to determine the solids quantity, density and elemental composition as well as to identify the crystalline phases present in the solids. The characterization results for the insoluble solids were evaluated versus 
those parameters important for transfer of radioactive slurries. If the solids are $>5 \mathrm{wt} \%$ and have a specific gravity of $>1.35 \mathrm{~g} / \mathrm{cc}$, additional evaluations related to tank farm transfer capabilities are needed [Jo, 2013, section 3.5.1]. This phase of testing did not fully mimic scaling tendency on metallic evaporator surfaces. Future testing phases will examine deposition of scale on steel evaporator components if aluminosilicate solids or other known scale-formers are identified in preliminary tests.

One option that has been previously evaluated is disposal of the LAW Off-Gas Condensate stream directly to the ETF. This option has a number of consequences to ETF including increases in waste volume, halide levels and radioactivity [Lueck, 2008; May, 2009]. Routing this stream to ETF may increase the volume of waste to be treated at ETF, and will change its composition and treatment requirements. Sending this stream to ETF would cause the halide concentration in that evaporator to increase substantially, which is expected to impact corrosion [Lueck, 2008]. Likewise, the radionuclide content would substantially increase, and would challenge existing treatment capabilities [May, 2009]. If the radionuclides are removed from the Off-Gas Condensate stream in an alternate process and the decontaminated liquid was then sent to the ETF, the fluoride, sulfate, and chloride would be purged from the LAW system, yielding substantial benefits to WTP and mitigating the consequences of radioactive contamination, but impacting ETF. Testing of this alternative process was performed at SRNL as another part of this strategic task. The evaporation testing reported here would then apply to the ETF evaporator, although it operates at atmospheric pressure and higher temperature, which could impact scale formation. A more detailed evaluation of the impact on the ETF and Waste Solidification Unit (WSU) throughput would also be needed in the future, after waste stream compositions and radionuclide contents are better defined.

\subsection{Experimental Procedure}

\subsection{Simulant Preparation}

The HTWOS output file for the SBS and WESP combined streams, converted to concentrations, is shown in Appendix A. This is derived from a run of HTWOS model by WRPS, documented in SVF-2732 MMR-13-008 data Case 1 rev 0. The data shown is the average, maximum, and minimum concentrations for all batches for the entire WTP mission duration. Since condensate recycle from the HLW melter is included, these results will be conservative should the LAW facility commence operations prior to operation of the Pretreatment facility. The aqueous phase was prepared from dissolution of laboratory chemicals, as shown in Table 2-1.

A single batch of $3.5 \mathrm{~L}$ of simulant (i.d.: SBS Sim. batch 1) was prepared and used for the neutral evaporation tests. A duplicate batch of $3.5 \mathrm{~L}$ of simulant (i.d.: SBS Sim. batch 2) was also prepared at the same time as SBS Sim batch 1 and was later used for the alkaline solution evaporation tests as described below in Section 2.3. The glass formers were then added to both simulants, and mixed for five days at ambient temperature of $\sim 23{ }^{\circ} \mathrm{C}$. The filtrate $\mathrm{pH}$ was measured to be 8.2 after mixing for both the SBS Sim. batch 1 and SBS Sim. batch 2. These simulants were adjusted to a $\mathrm{pH}$ of $7.3 \pm 0.3$, each with $\sim 50$ drops of concentrated nitric acid. 
Table 2-1. Aqueous Simulant Formulation

\begin{tabular}{|l|l|c|}
\hline \multicolumn{1}{|c|}{ Chemical } & \multicolumn{1}{c|}{ Formula } & $\begin{array}{c}\text { Mass (g)/L } \\
\text { simulant }\end{array}$ \\
\hline $\begin{array}{l}\text { Aluminum nitrate } \\
\text { nonahydrate }\end{array}$ & $\mathrm{Al}\left(\mathrm{NO}_{3}\right)_{3} \cdot 9 \mathrm{H}_{2} \mathrm{O}$ & 0.400 \\
\hline Sodium chromate & $\mathrm{Na}_{2} \mathrm{CrO}_{4}$ & 0.283 \\
\hline Potassium chloride & $\mathrm{KCl}$ & 0.219 \\
\hline Sodium chloride & $\mathrm{NaCl}$ & 1.395 \\
\hline Sodium fluoride & $\mathrm{NaF}$ & 3.209 \\
\hline Ammonium nitrate & $\mathrm{NH}_{4} \mathrm{NO}_{3}$ & 4.760 \\
\hline Sodium nitrate & $\mathrm{NaNO}_{3}$ & 1.221 \\
\hline Sodium nitrite & $\mathrm{NaNO}_{2}$ & 0.016 \\
\hline Ammonium sulfate & $\left(\mathrm{NH}_{4}\right)_{2} \mathrm{SO}_{4}$ & 3.220 \\
\hline $\begin{array}{l}\text { Dibasic sodium } \\
\text { phosphate dihydrate }\end{array}$ & $\mathrm{Na}_{2} \mathrm{HPO}_{4} \cdot 2 \mathrm{H}_{2} \mathrm{O}$ & 0.040 \\
\hline
\end{tabular}

The glass formers added to the simulant are shown in Table 2-2. Sucrose was excluded because it is destroyed in the melter and thus not expected to impact the results obtained here.

Table 2-2. Glass Formers

\begin{tabular}{|l|l|c|}
\hline \multicolumn{1}{|c|}{ Mineral } & \multicolumn{1}{|c|}{ Formula } & $\begin{array}{c}\text { Mass (g)/L } \\
\text { simulant }\end{array}$ \\
\hline kyanite & $\mathrm{Al}_{2} \mathrm{SiO}_{5}$ & 0.745 \\
\hline borax & $\mathrm{Na}_{2} \mathrm{~B}_{4} \mathrm{O}_{7} \cdot 10 \mathrm{H}_{2} \mathrm{O}$ & 0.0123 \\
\hline boric acid & $\mathrm{H}_{3} \mathrm{BO}_{3}$ & 1.430 \\
\hline wollastonite & $\mathrm{CaSiO}_{3}$ & 0.772 \\
\hline iron oxide (hematite) & $\mathrm{Fe}_{2} \mathrm{O}_{3}$ & 0.430 \\
\hline lithium carbonate & $\mathrm{Li}_{2} \mathrm{CO}_{3}$ & 0.392 \\
\hline forsterite olivine & $\mathrm{Mg}_{2} \mathrm{SiO}_{4}-\mathrm{Fe}_{2} \mathrm{SiO}_{4}$ & 0.257 \\
\hline sodium carbonate & $\mathrm{Na}_{2} \mathrm{CO}_{3}$ & 0.003 \\
\hline silica & $\mathrm{SiO}_{2}$ & 2.857 \\
\hline rutile & $\mathrm{TiO}_{2}$ & 0.114 \\
\hline zinc oxide & $\mathrm{ZnO}_{2}$ & 0.286 \\
\hline zircon & $\mathrm{ZrSiO}_{4}$ & 0.372 \\
\hline sucrose & $\mathrm{C}_{12} \mathrm{H}_{22} \mathrm{O}_{11}$ & 0 \\
\hline & & 7.67 \\
\hline
\end{tabular}

Samples were analyzed for elemental composition by Inductively Coupled Plasma - Atomic Emission Spectroscopy (ICP-AES), and for anions and ammonium by Ion Chromatography. 
Solids formed on concentration in the evaporator were analyzed by X-ray Diffraction (XRD) Spectroscopy.

\subsection{Simulant Evaporation at Neutral pH}

The vacuum evaporator test apparatus is shown in Figure 2-1. The liquid was introduced into the evaporator feed pot, the vacuum was applied, and the pot with solution was heated and agitated with a magnetic stir bar. The condensate was collected using a glass condenser chilled with a recirculating water stream at approximately $1{ }^{\circ} \mathrm{C}$. A secondary condenser was utilized, which consisted of a small flask submerged in an ice bath. As the evaporation continued, additional feed solution was periodically introduced via a suction line to the feed pot. Although this temporarily cooled the feed pot, the vacuum was not broken. Condensate and samples from the pot were periodically removed by breaking the vacuum and emptying the condensate collection vessel.

Figure 2-2 is a labeled photograph of the apparatus as operated in a laboratory chemical hood. The pressure sensor readout is near the left side. It indicates absolute pressure in units of inches of mercury to two decimal places.

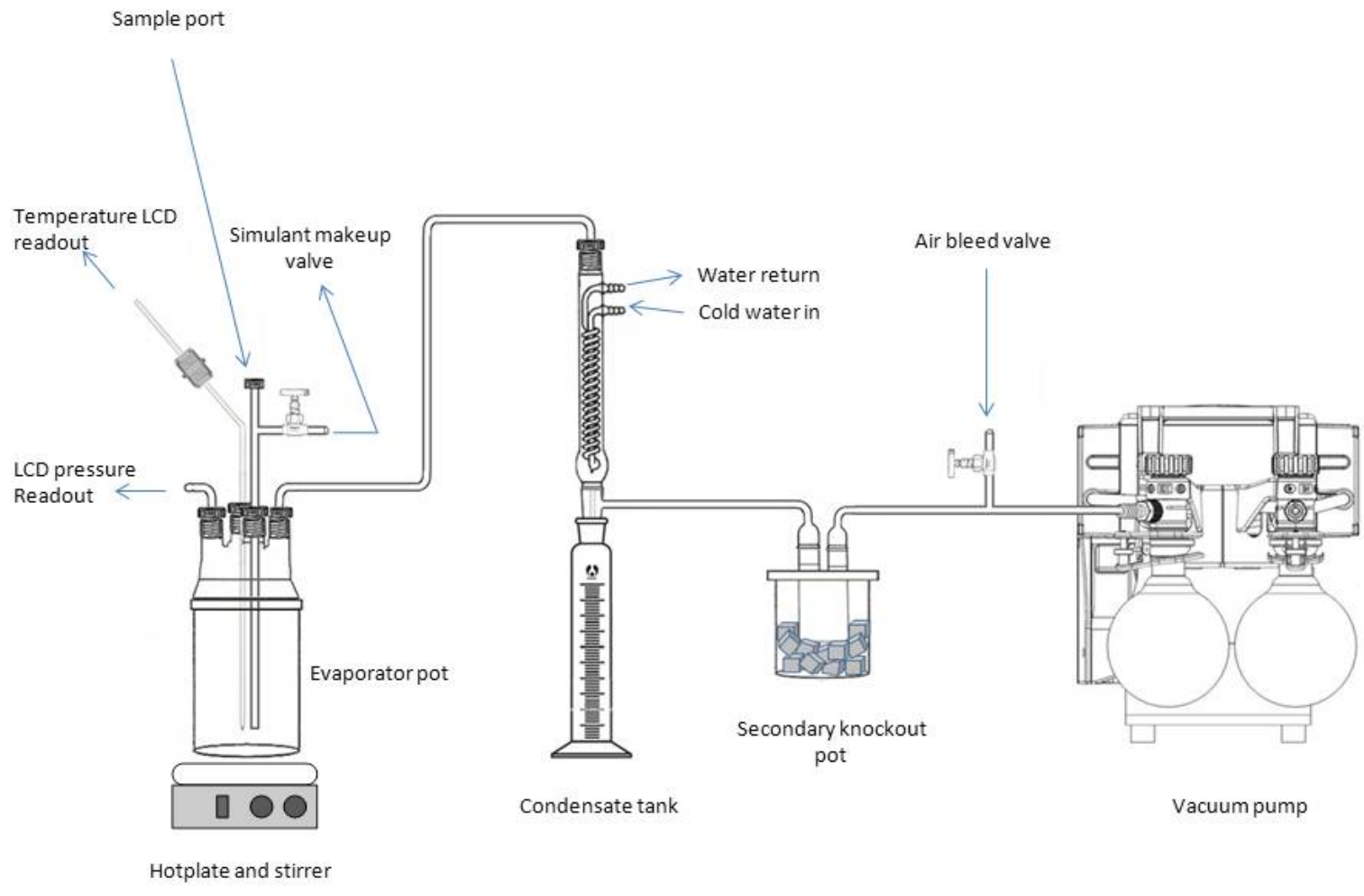

Figure 2-1. Evaporator Apparatus Diagram 


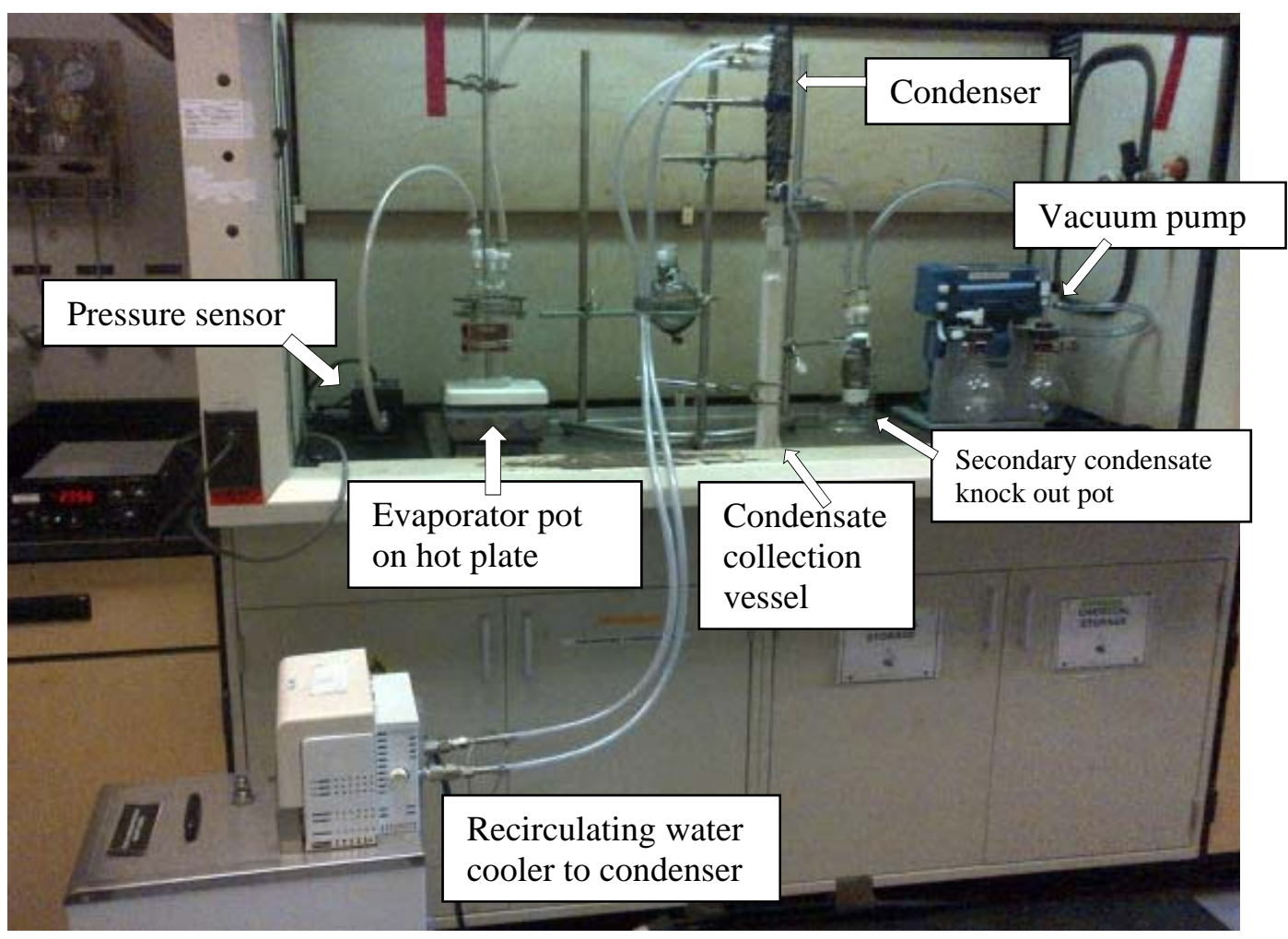

Figure 2-2. Image of Evaporator Apparatus

The simulant was prepared (3.5 L) for evaporation by first filtering it ( 0.45 micron nylon filter) to remove insoluble solids including much of the glass former mass. Density of the simulant was measured to be $1.008 \mathrm{~g} / \mathrm{mL}$ at room temperature, and 3,000 $\mathrm{mL}$ (3024.8 g) was weighed into a separate container for use. Filtrate $(400 \mathrm{~mL})$ was initially loaded into the evaporator pot. Pressure was adjusted to $8 \mathrm{kPa}$ (60 torr, 2.35 inches of mercury absolute (comparable to conditions used for boil-down tests for the 242-A evaporator [Callaway, 2010]), and the hot plate and magnetic stir-bar were turned on. The solution boiled at approximately $43{ }^{\circ} \mathrm{C}$. After evaporating $200 \mathrm{~mL}$, an additional $200 \mathrm{~mL}$ of (room temperature) filtrate was added to the pot to maintain the liquid level. This cycle was repeated until the $3 \mathrm{~L}$ of simulant was evaporated down to an equivalent of $100 \mathrm{~mL}$. (The actual final volume was less because of extracted sample volumes.)

Samples were collected at concentration points corresponding to $7.5 \mathrm{X}, 18 \mathrm{X}, 24 \mathrm{X}$, and $30 \mathrm{X}$. The original sample names and condensate removal plan is shown in Table 2-3. However, measured masses and volumes were used to calculate actual concentrations in the pot and these are shown in Table 2-4. Figures in this report that use sample concentration factor use the calculated value. Table 2-3 did not account for "Pre-7.5X" samples because it was not known prior to the test initiation when they would be taken. Table 2-4 results do account for volume removed by that sample.

The purpose of the "Pre-7.5X" sample was to take a sample when turbidity was first visually observed in the pot. In the neutral campaign, that sample was taken when the level in the pot was low (vs. level restored to $400 \mathrm{~mL}$ ), resulting in the higher-than expected sample 
concentration. The "Pre-7.5X" sample for the alkaline campaign was taken after the pot was refilled, so concentration factor increases with time for that campaign.

Table 2-3. Evaporation Sampling Matrix

\begin{tabular}{|l|c|c|c|}
\hline $\begin{array}{l}\text { Concentration of } \\
\text { samples }\end{array}$ & $\begin{array}{l}\text { Volume of } \\
\text { solution in } \\
\text { pot } \mathbf{( m L )}\end{array}$ & $\begin{array}{l}\text { Total Volume of } \\
\text { solution } \\
\text { evaporated (mL) }\end{array}$ & $\begin{array}{l}\text { Incremental } \\
\text { condensate } \\
\text { collected (mL) }\end{array}$ \\
\hline $7.5 X$ & 400.0 & $2,600.0$ & 2,600 \\
\hline After 7.5X sample & 380.0 & & (empty vessel) \\
\hline $18 X$ & 158.33 & 2821.67 & 221.67 \\
\hline After 18X sample & 138.33 & & \\
\hline 24X & 103.75 & 2856.25 & 34.58 \\
\hline After 24X sample & 83.75 & & 16.75 \\
\hline 30X & 67.00 & 2873 & \\
\hline End of Run & 47.00 & 2873 & \\
\hline
\end{tabular}

Table 2-4. Named vs. Actual Pot Sample Concentrations

\begin{tabular}{|c|c|c|}
\hline Sample Name & $\begin{array}{c}\text { Neutral Campaign } \\
\text { Calculated } \\
\text { Concentration }\end{array}$ & $\begin{array}{c}\text { Alkaline Campaign } \\
\text { Calculated } \\
\text { Concentration }\end{array}$ \\
\hline Pre-7.5X & 11.0 & 3.4 \\
\hline $7.5 X$ & 7.0 & 7.3 \\
\hline $18 X$ & 16.6 & 17.5 \\
\hline $24 X$ & 22.1 & 23.3 \\
\hline $30 X$ & 27.6 & 29.1 \\
\hline
\end{tabular}

\subsection{Simulant Evaporation at Alkaline pH}

The simulant (including glass formers) was prepared (3.5 L) for evaporation by first adjusting with sodium nitrite and sodium hydroxide to meet the Hanford tank waste storage requirement [Jo, 2013, Table 3-10]. Sodium nitrite (5 g) was added to reach $\sim 0.07 \mathrm{M}$ nitrite, and sodium hydroxide (70 g of $50 \mathrm{wt} \% \mathrm{NaOH}$ solution) to raise the $\mathrm{pH}$ to 12.6. The adjusted solution was agitated for 5 days; and the $\mathrm{pH}$ was monitored to ensure it did not fall below $\mathrm{pH} 12$. No additional sodium hydroxide addition was needed. The adjusted solution was then filtered using a 0.45 micron nylon filter to remove insoluble solids, and the filtrate solution was sampled for analysis. Density of the simulant was measured to be $1.018 \mathrm{~g} / \mathrm{mL}$ at room temperature, and 3000 $\mathrm{mL}$ (3054.4 g) was weighed into a separate container for use. The filtrate $(400 \mathrm{~mL})$ was then loaded into the evaporator pot. Pressure was adjusted to $8 \mathrm{kPa}$ (60 torr), and the hot plate and magnetic stir-bar were turned on. The solution boiled at approximately $43{ }^{\circ} \mathrm{C}$. After evaporating and collecting $250 \mathrm{~mL}$ of condensate, an additional $250 \mathrm{~mL}$ of filtrate was added to the pot to 
maintain the liquid level, and evaporation continued. This cycle was repeated until the $3 \mathrm{~L}$ of simulant was almost entirely evaporated. Samples were collected at concentration points corresponding to pre-7.5X, 7.5X, 18X, 24X, and 30X (each concentration calculation accounted for the withdrawal of the preceding periodic samples), using the same matrix as shown in Table 2-3. The "Pre-7.5X" sample was again to be taken when turbidity in the pot first became visible.

\subsection{Quality Assurance}

This test program is described in the Task Technical and Quality Assurance Plan for Developing a Flowsheet for Off-Gas Process Liquids from the Hanford Low Activity Waste Vitrification Process [Wilmarth, 2013]. Requirements for performing reviews of technical reports and the extent of review are established in manual E7 2.60. SRNL documents the extent and type of review using the SRNL Technical Report Design Checklist contained in WSRC-IM-2002-00011, Rev. 2.

\subsection{Results and Discussion}

\subsection{Simulant Composition}

Results of the duplicate chemical analysis of the neutralized, filtered simulants are shown in Table 3-1. These match the target composition from the WRPS model calculation (see 'Average Case $1 \mathrm{LAW}+2^{\text {nd }}$ LAW' in Appendix A) reasonably well, although more ammonium was inadvertently added than the target ( 18\% higher than the 'Average' case and $\sim 9 \%$ higher than the 'Maximum' case). Future formulations will modify the amount of ammonium added to more closely match the projection, but this is expected to be conservative and only minimally impact results obtained here. Excess sodium ion was added versus the model projection in order to compensate some of the charge balance. The nitrate from chemicals was slightly low, but most of this was partially compensated by the addition of nitric acid to neutralize the $\mathrm{pH}$, resulting in $4.88 \mathrm{~g} / \mathrm{L}$ nitrate versus a target of $5.53 \mathrm{~g} / \mathrm{L}$. The presence of boron, lithium, silicon, and zinc are due to dissolution of the glass former solids. The target concentration for soluble aluminum was $\sim 29 \mathrm{mg} / \mathrm{L}$, or $101 \mathrm{mg} / \mathrm{L}$ as $\mathrm{Al}(\mathrm{OH})_{4}{ }^{-}$from Appendix A, based on computer modeling and comparison to the pilot scale melter off-gas condensate sample analyses [Matlack, 2006]. However, attempts to dissolve the aluminum (added as $0.4 \mathrm{~g} / \mathrm{L}$ aluminum nitrate nonahydrate) by manipulation of the sequence of chemical addition and temperature were unsuccessful. One possible explanation for less than detectable soluble $\mathrm{Al}$ in this system is formation of cryolite $\left(\mathrm{Na}_{3} \mathrm{AlF}_{6}\right)$ precipitate, which along with gibbsite $\left(\mathrm{Al}(\mathrm{OH})_{3}\right)$, is known to form in various natural water solutions [Roberson and Hem, 1969]. The analyzed soluble fluoride in this system was about $200 \mathrm{mg} / \mathrm{L}$ lower $(1.25 \mathrm{E} 3 \mathrm{mg} / \mathrm{L})$ than the targeted as-batched fluoride $(1.45 \mathrm{E} 3 \mathrm{mg} / \mathrm{L})$, presumably due to precipitation with glass formers. 
Table 3-1. Neutralized Simulant Filtrate Chemical Composition

\begin{tabular}{|c|c|c|c|c|c|}
\hline & \multicolumn{2}{|c|}{ SBS Sim. batch 1} & \multicolumn{2}{|c|}{ SBS Sim. batch 2} & \multirow{2}{*}{$\begin{array}{c}\text { HTWOS } \\
\text { Avg. [SVF- } \\
\text { 2732] }\end{array}$} \\
\hline Component & $\begin{array}{c}\text { Concentration } \\
(\mathrm{mg} / \mathrm{L})\end{array}$ & $\begin{array}{l}\text { Standard } \\
\text { Deviation }\end{array}$ & $\begin{array}{c}\text { Concentration } \\
(\mathrm{mg} / \mathrm{L})\end{array}$ & $\begin{array}{l}\text { Standard } \\
\text { Deviation }\end{array}$ & \\
\hline $\mathrm{Al}$ & $<0.100$ & & $<0.100$ & & 28 \\
\hline B & 252 & 1 & 258 & 7 & $\mathrm{GF}^{1}$ \\
\hline $\mathrm{Ca}$ & $<0.100$ & & $<0.100$ & & GF \\
\hline $\mathrm{Cr}$ & 88.5 & 1.3 & 88.9 & 0.6 & 91 \\
\hline $\mathrm{Fe}$ & $<0.100$ & & $<0.100$ & & GF \\
\hline $\mathrm{K}$ & 148 & 1 & 146 & 2 & 115 \\
\hline $\mathrm{Li}$ & 78.1 & 1.0 & 78.2 & 0.6 & GF \\
\hline $\mathrm{Mg}$ & $<0.100$ & & $<0.100$ & & GF \\
\hline $\mathrm{Na}$ & 2980 & 28 & 2980 & 21 & 2290 \\
\hline $\mathrm{P}$ & $<10.0$ & & $<10.0$ & & $7\left(\right.$ as $\mathrm{PO}_{4}^{-3}$ ) \\
\hline $\mathrm{S}$ & 814 & 5 & 830 & 1 & $780\left(\right.$ as $\left.\mathrm{SO}_{4}^{-2}\right)$ \\
\hline Si & 51.2 & 1.0 & 50.9 & 0.4 & GF \\
\hline $\mathrm{Ti}$ & $<0.100$ & & $<0.100$ & & GF \\
\hline $\mathrm{Zn}$ & 26.7 & 0.6 & 26.2 & 0.6 & GF \\
\hline $\mathrm{Zr}$ & $<0.100$ & & $<0.100$ & & GF \\
\hline $\mathrm{F}^{-}$ & $1.25 \mathrm{E} 3$ & 7 & $1.25 \mathrm{E} 3$ & 14 & $1.45 \mathrm{E} 3$ \\
\hline $\mathrm{Cl}^{-}$ & 937 & 1 & 934 & 6 & 950 \\
\hline $\mathrm{NO}_{2}^{-}$ & $<10$ & & $<10$ & & 10.7 \\
\hline $\mathrm{NO}_{3}^{-}$ & 4.89E3 & 7 & $4.87 \mathrm{E} 3$ & 28 & $5.53 \mathrm{E} 3$ \\
\hline $\mathrm{SO}_{4}^{-2}$ & 2.33E3 & 28 & $2.40 \mathrm{E} 3$ & 7 & $2.34 \mathrm{E} 3$ \\
\hline $\mathrm{PO}_{4}^{-3}$ & $<10$ & & $<10$ & & 21.5 \\
\hline $\mathrm{NH}_{4}^{+}$ & $1780^{*}$ & & $1790 *$ & & $1.51 \mathrm{E} 3$ \\
\hline
\end{tabular}

*analysis of single sample

${ }^{1}$ Glass Former component; minimal HTWOS projected concentration

\subsection{Calibration of the Evaporator Equipment}

After the evaporator rig was assembled, it was tested with deionized (DI) water. Figure 3-1 shows how the equipment provided a water saturation pressure that was slightly (about 5\%) below that of an Antoine equation and other literature data [Reid, 1977; CRC, 1975]. This corresponds to about 1 inch of water in pressure. It is believed that the hydrostatic pressure within the liquid causes the (submerged) pot thermocouple to read higher than the upper surface temperature of the water. At $40{ }^{\circ} \mathrm{C}$, a pressure of $7.08 \mathrm{kPa}$ (2.09 inches of mercury) was observed when the vapor pressure of water there was $7.36 \mathrm{kPa}$ (2.17 inches of mercury, or 55.2 torr). 


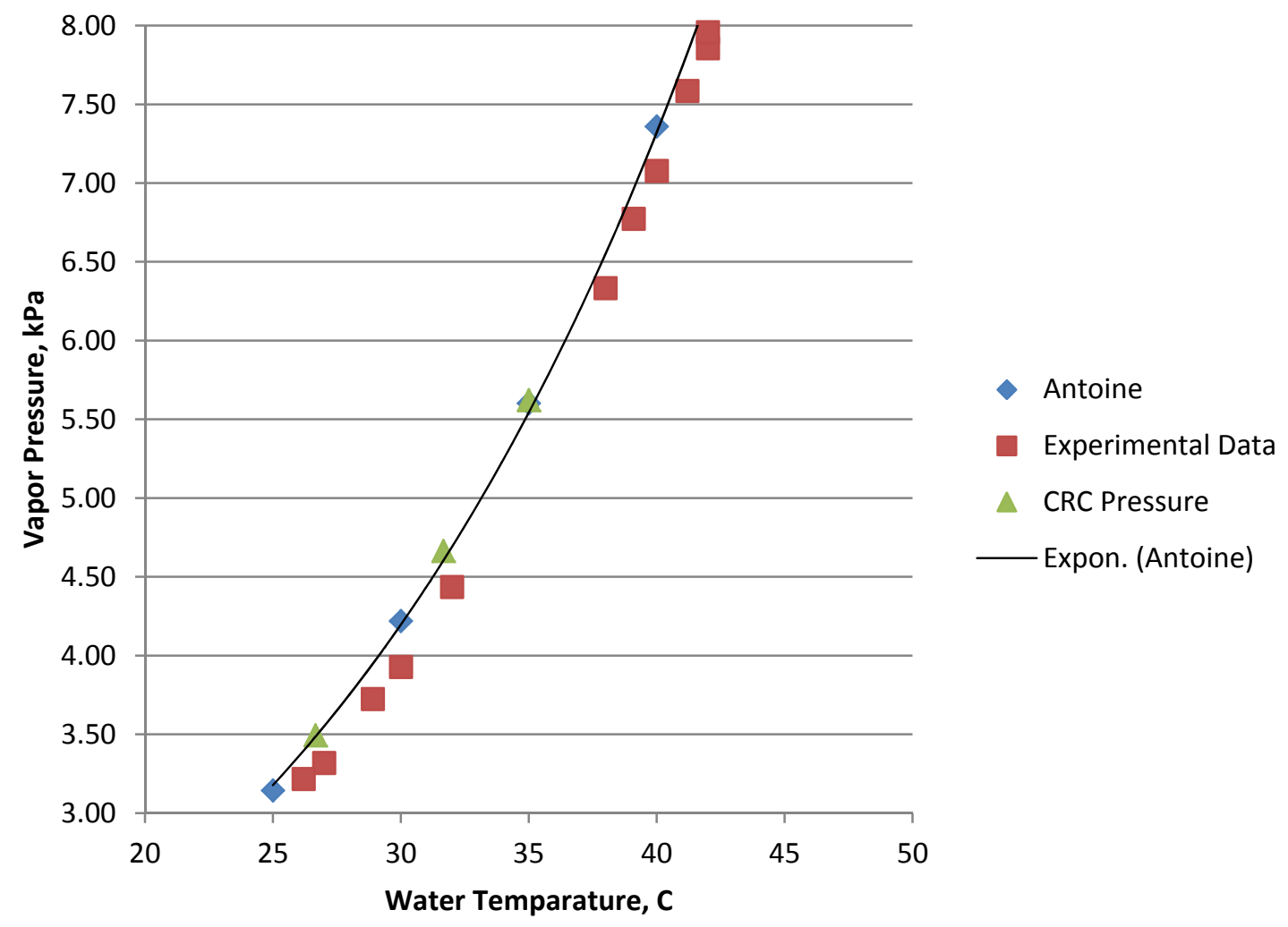

Figure 3-1. Water Vapor Pressure vs. Temperature

\subsection{Evaporation at Neutral pH}

The first campaign concentrated a 3-L batch of filtered SBS simulant that was at neutral $\mathrm{pH}$ and did not undergo caustic adjustment. Pressure was held to $8 \mathrm{kPa}$ (60 torr) for the test, though some divergence was detected at high concentration in the pot. On the first day of the campaign, the pot was boiled for 7.25 hours, reaching a concentration of $2.4 \mathrm{X}$. The pot and system were shut down overnight, and cooled to room temperature and rose to atmospheric pressure. Figure $3-2$ shows data for the second day, where the temperature remained at about $43{ }^{\circ} \mathrm{C}$ up to nearly the end of the campaign. Increasing temperature and decreasing vapor pressure was only seen in the last hour of running on the second day. In Figure 3-2, pressure/temperature data were recorded just after pot sampling and restart. The $7 \mathrm{X}$ label is the actual pot concentration versus feed at the time ("7.5X" sample). No foaming or unusual splattering was observed during the test.

Figure 3-3 shows the concentrate at the end of the campaign. The " $30 \mathrm{X}$ " concentration was calculated by mass balances to be 27.6X the feed concentration. The bright orange color comes from the chromate in the feed. 
SRNL-STI-2013-00713

Revision 0

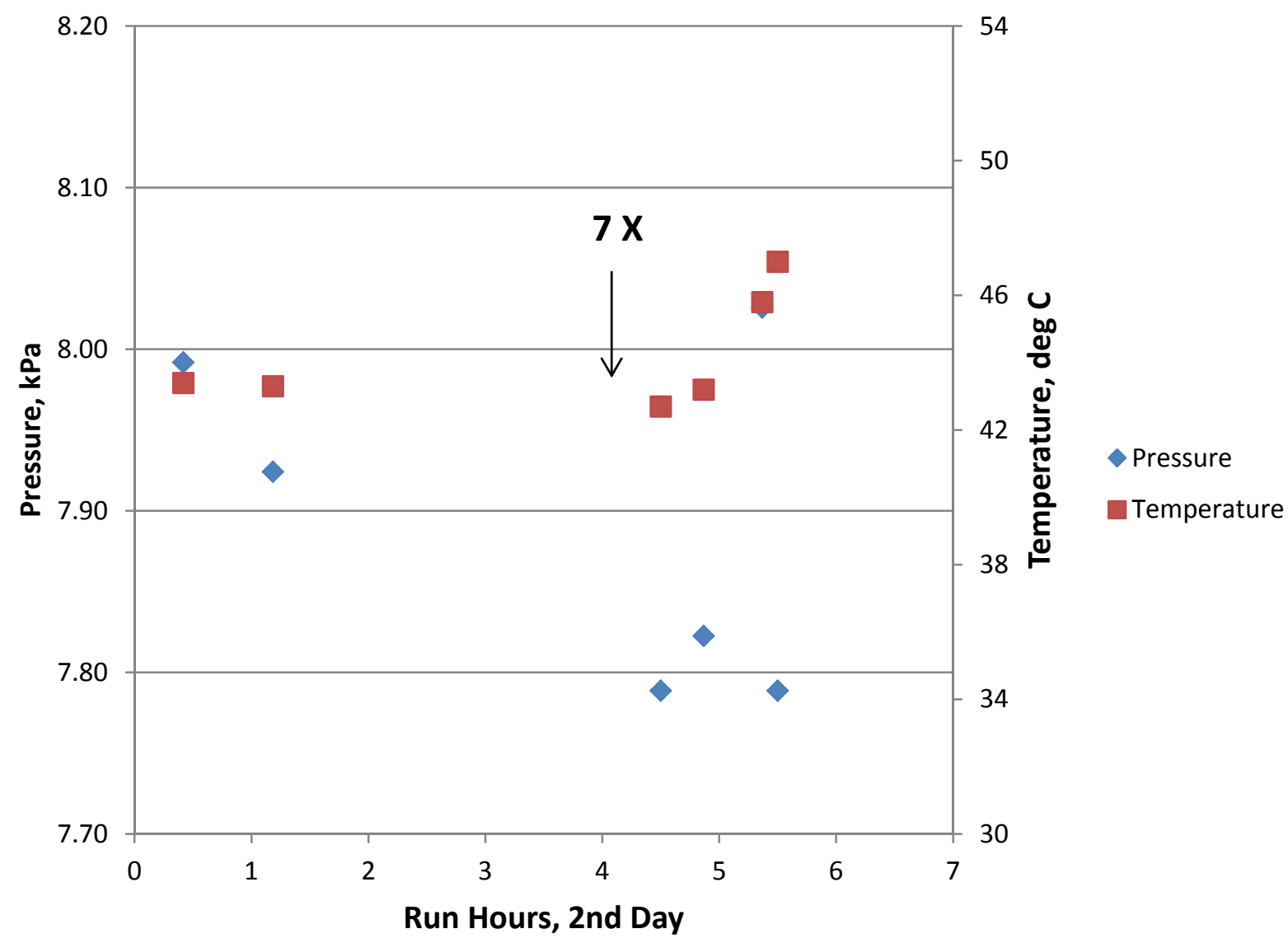

Figure 3-2. Evaporator Pressure and Temperature; $2^{\text {nd }}$ Day; Neutral Campaign 


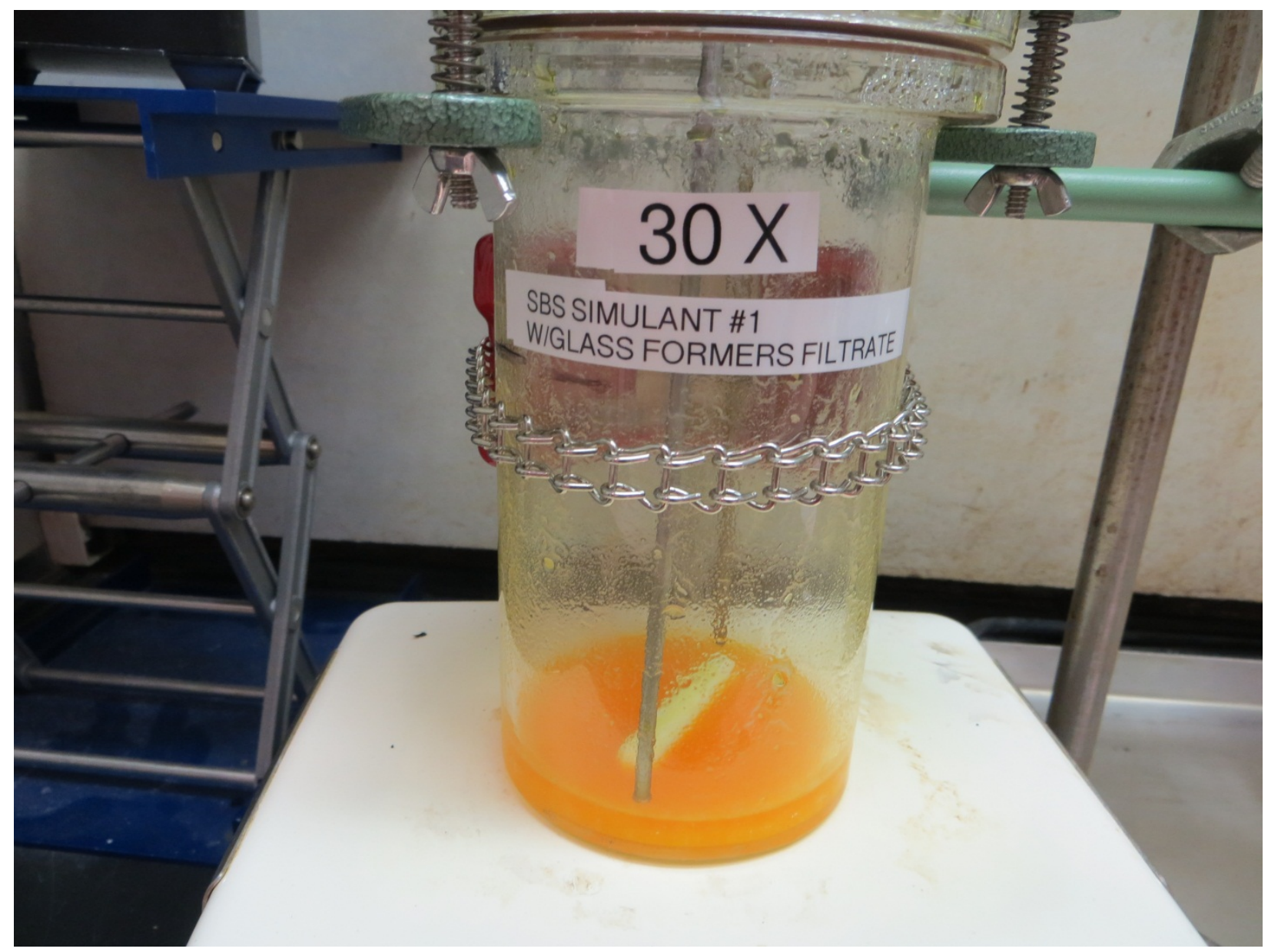

Figure 3-3 Image of Evaporator Pot at 30X Concentration; Neutral Campaign

Figures 3-4 and 3-5 show elemental concentrations compared to the feed. The Pre-7.5X sample is actually an $11 \mathrm{X}$ concentration factor sample because that sample was taken just before the evaporator pot was refilled at one point. This raised its effective concentration factor over that of the following $7.5 \mathrm{X}$ sample. In all other cases for both campaigns, the pot was sampled (7.5X and later) after the feeding steps were complete.

Aluminum is not included in Figure 3-4 because its concentration was below detection in the neutral campaign. During the simulant development, the $28 \mathrm{mg} / \mathrm{L}$ of soluble aluminum in the initial aqueous solution had been removed from solution when glass formers were added.

Lithium, silicon, and zinc did not remain fully soluble during evaporation. The XRD results for the solids from the last sample (30X concentration), shown in Figure 3-6, identified lithium fluoride, sodium zinc fluoride, and sodium fluorosilicate. The sodium nitrate (nitratine) is presumably due to crystallization the residual liquid adhered to the solids when the sample was collected. The other fluoride-containing species have relatively high water solubility. However, kogarkoite is known to form scale in the aluminum industry [Konigsberger, 2007], so would need to be controlled to prevent evaporator issues. The ICP-AES data indicated that significant 
amounts of sulfur are absent from solution above $\sim 20 \mathrm{X}$ concentration, consistent with the XRD identification of Kogarkoite as a sulfate-bearing species present as a solid.

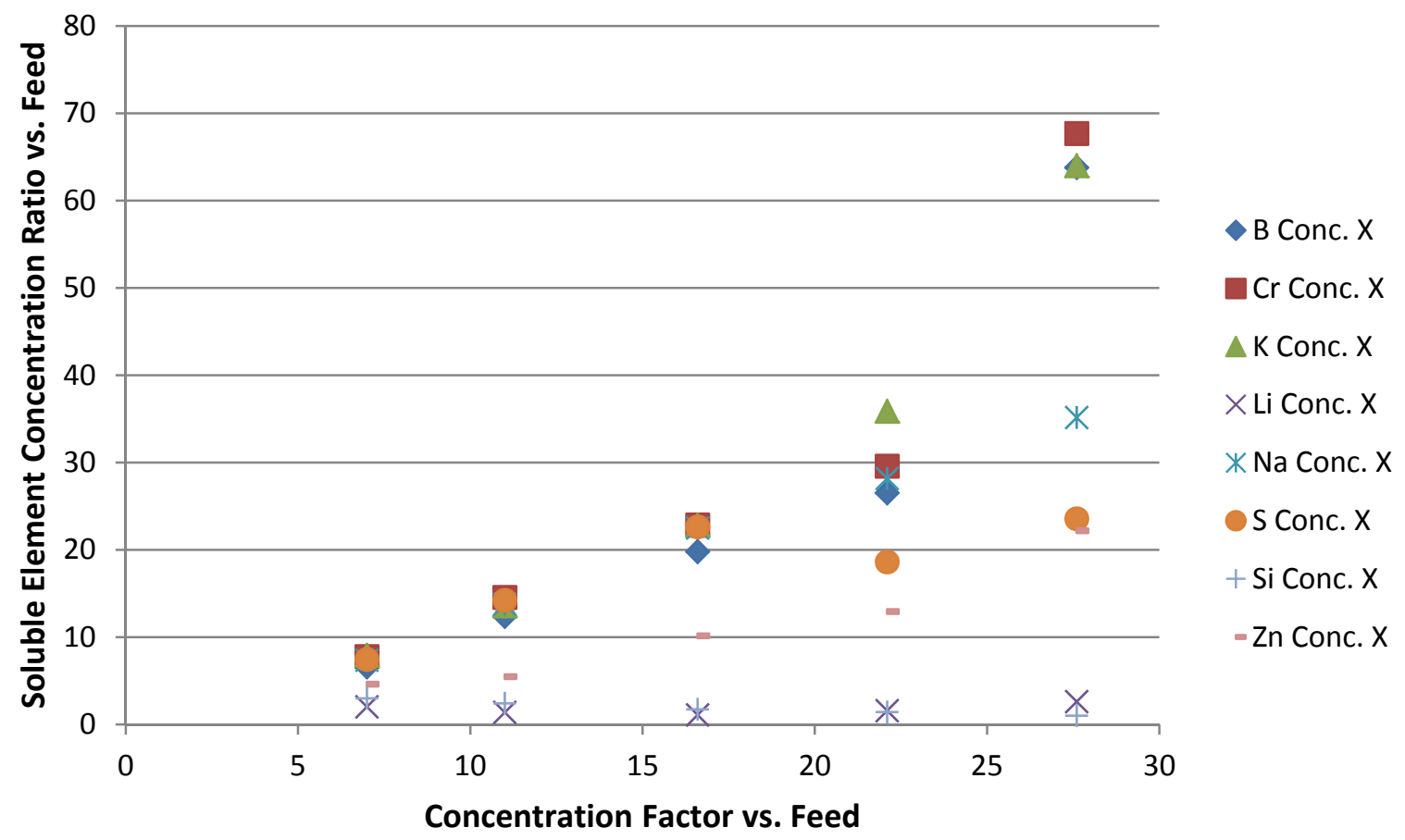

Figure 3-4. Soluble Element Concentration Ratios vs. Concentration, Neutral Campaign 


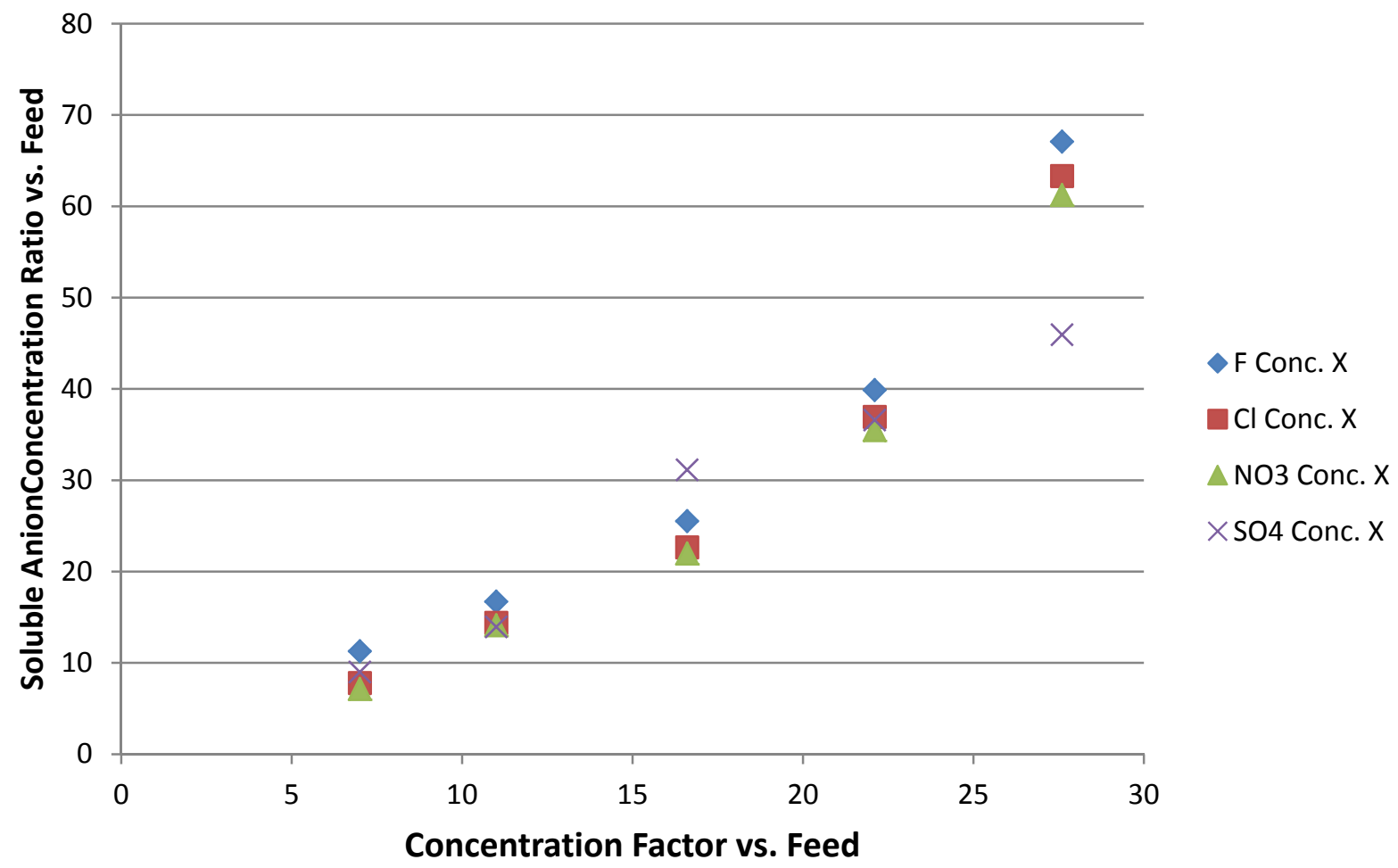

Figure 3-5. Soluble Anion Concentration Ratios vs. Concentration, Neutral Campaign

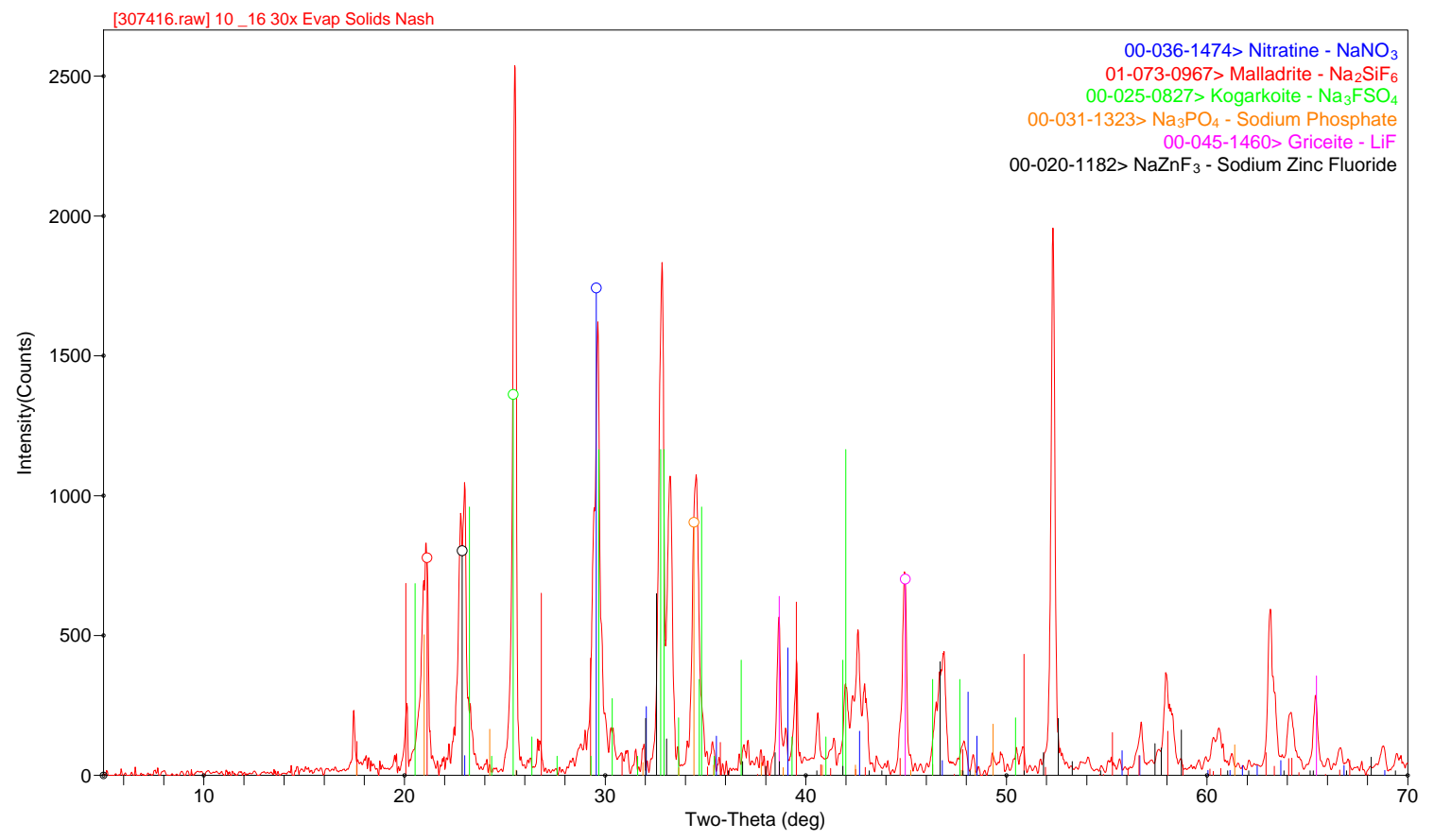

Figure 3-6. X-Ray Diffraction Data from 30X Sample, Neutral Campaign 
Boron, chromium, and potassium concentration in solution exceeded that calculated based on the concentration factor, evidently because they were partitioning to the aqueous phase only, versus the total of liquid and solid. Sodium appeared to track the concentration factor pretty well, and does not appear to partition only to the aqueous phase, but this was likely because some was included in crystal phases.

Figure 3-7 shows that pot sample (liquid or slurry) density increased as expected for both campaigns. Measurements were performed on the samples after they had cooled to room temperature. The pot contents' density remained below $1.3 \mathrm{~g} / \mathrm{mL}$ for the first (neutral $\mathrm{pH}$ ) campaign, but was above it at $\sim 15 X$ concentration for the alkaline campaign.

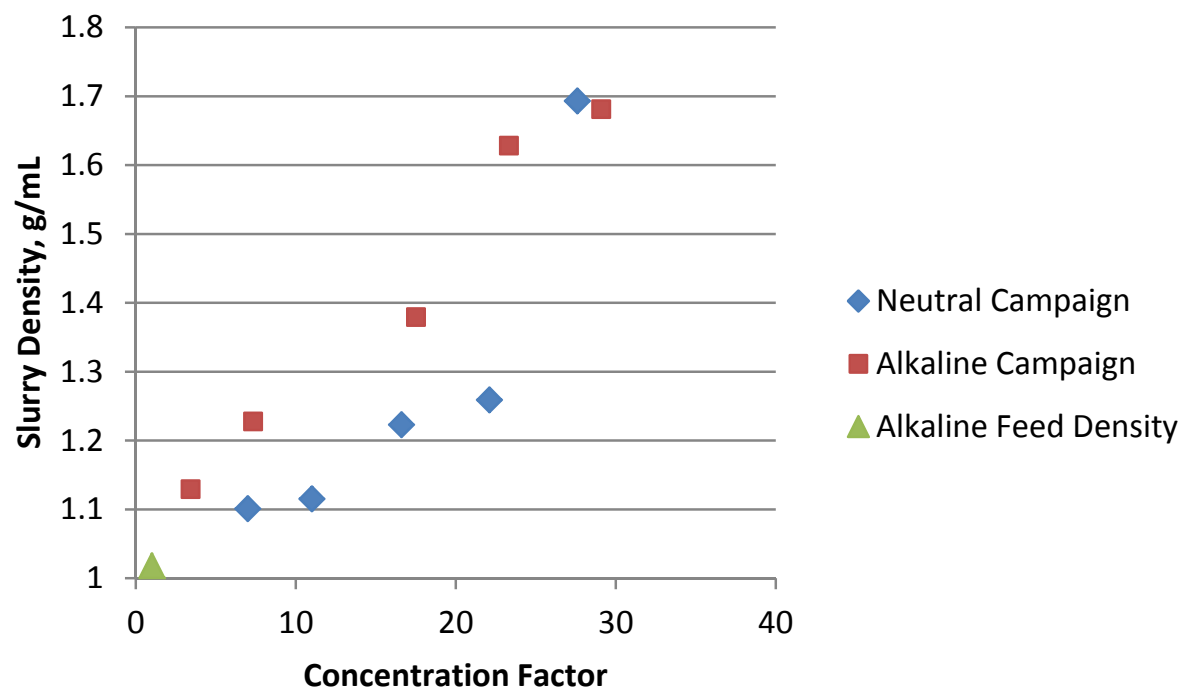

Figure 3-7. Pot Sample Density versus Concentration Factor

The stripping and carryover of ammonia at neutral $\mathrm{pH}$ indicates that it only partitions to the vapor at very high ionic strength. The composition of the water condensate, Figure 3-8, shows that ammonia stripping increased with pot concentration, but was significant at all times, even though it was primarily present as ammonium ion initially. The feed ammonium ion level was $1780 \mathrm{mg} / \mathrm{L}$, and the condensate approached that concentration of ammonium ion (ammonium hydroxide) by the end of the campaign. Conversely, the alkaline campaign showed substantial stripping of ammonia in the initial evaporation, as expected, which decreased toward the end, presumably due to depletion in the pot in the final two samples. The condensate was slightly turbid but colorless in the neutral campaign, and clear and colorless in the alkaline campaign. 


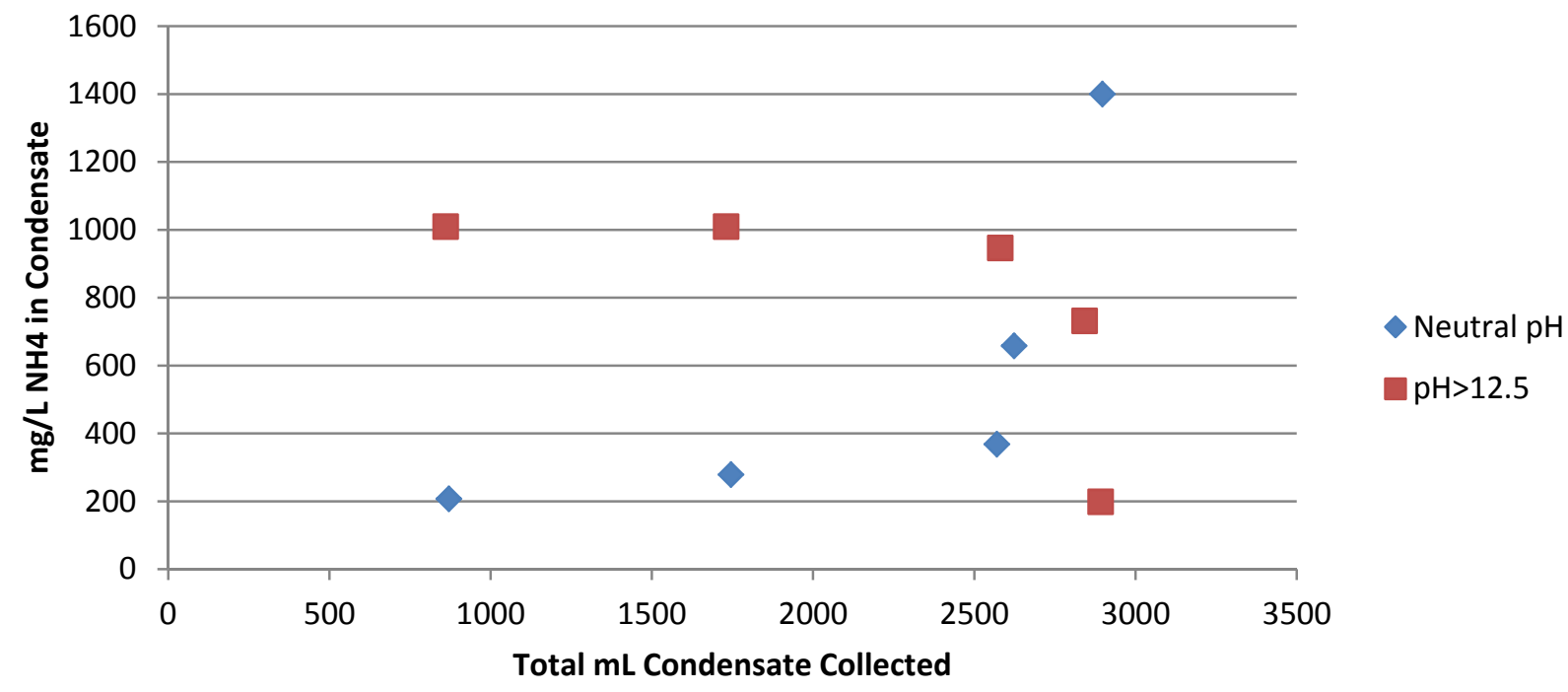

Figure 3-8. Condensate Ammonia Concentration versus Total Condensate volume, Both Campaigns

Other than the final 30X samples, too little insoluble solids were present to accurately measure the wt\% insoluble solids in the evaporator pot slurry, which has a detection limit of approximately $1 \mathrm{wt} \%$. Since the solids are soluble in water, it was not practical to use alternate methods, which require washing the solids to remove interstitial liquids. In order to estimate the insoluble solids concentration, the samples ( $10 \mathrm{~g}$ ) were filtered, and the solids were extracted in $\sim 10 \mathrm{~mL}$ of water. Both the filtrate and the extract were then analyzed by ICP-AES and IC. Detailed results of the analyses are shown in Appendix B. To calculate the amount of a species in the insoluble solids versus in interstitial liquid, potassium was selected as the reference concentration, since it was observed to remain soluble throughout both campaigns, as expected. The quantity of potassium present in the extract was used to calculate the amount of liquid absorbed onto the solids, and the mass fraction of each species assignable to the soluble portion was subtracted from the total. Results of the calculation for all species present that have one result at $>1 \mathrm{mg} / \mathrm{g}$ of slurry are shown in Table 3-2. Presumably, the fluoride and sulfate are present as the sodium salts or minerals identified in the XRD. It is likely that the absence of sufficient sodium ions to charge balance the anions is a result of analytical variability in measuring multiple samples with large amounts of sodium, which is much larger than the amount needed to charge balance the anions. The purpose of this analysis and calculation was to indicate when precipitated solids approach the $1 \mathrm{wt} \%$ limit. Small positive or negative numbers are statistically not distinguishable. The results indicate that the insoluble solids are $<1 \mathrm{wt} \%$ in all but the final, 30X sample.

An image of the evaporator pot samples is shown in Figure 3-9, with the samples in increasing concentration left to right (except that the "pre-7.5X sample is actually 11X concentration). The liquid is yellow-orange in color due to the chromate content. Other than the $30 \mathrm{X}$ sample, only a trace amount of insoluble white solids was visible. At 30X concentration, the bottle is approximately $25 \%$ full of insoluble white solids. 
Table 3-2 Calculated Quantity of Insoluble Species; Neutral Campaign

\begin{tabular}{|l|r|r|r|}
\hline $\begin{array}{l}\text { Concentration Factor, } \\
\text { (Sample Name) }\end{array}$ & \multicolumn{1}{|c|}{$\begin{array}{c}\mathrm{Na}^{+} \\
(\mathrm{mg} / \mathrm{g})\end{array}$} & $\begin{array}{c}\mathrm{F}^{-} \\
(\mathrm{mg} / \mathrm{g})\end{array}$ & $\begin{array}{c}\mathrm{SO}_{4}^{-2} \\
(\mathrm{mg} / \mathrm{g})^{* *}\end{array}$ \\
\hline Pre 7.5X & 0.49 & 7.9 & $-0.05^{*}$ \\
\hline $7.5 \mathrm{X}$ & 0.10 & 2.8 & -0.002 \\
\hline $18 \mathrm{X}$ & 0.21 & 2.9 & -0.079 \\
\hline $24 \mathrm{X}$ & 1.5 & 3.7 & 2.0 \\
\hline $30 \mathrm{X}$ & 39 & 50 & 60 \\
\hline \multicolumn{2}{|c|}{${ }^{*}$ negative numbers are the result of variability of analysis } \\
& **alculated as sulfate from ICP-ES analysis of sulfur
\end{tabular}

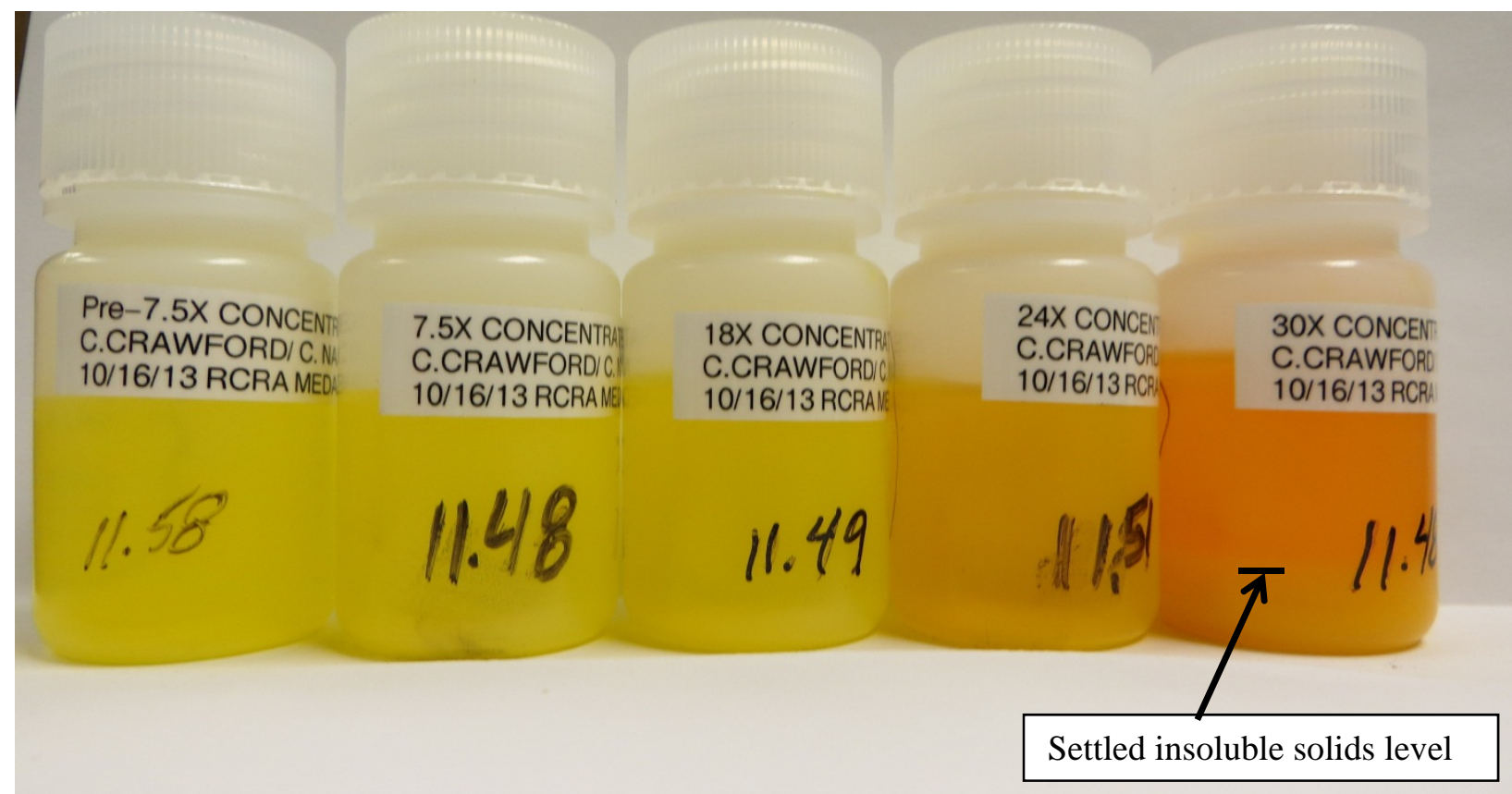

Figure 3-9 Image of Evaporator Pot Samples; Neutral Campaign

\subsection{Evaporation at alkaline $\mathrm{pH}$}

Evaporation of the caustic-adjusted simulant followed the same procedure as the previous campaign. Volumes and pressure were held to similar values. On the first day of the alkaline campaign, the pot was boiled for 8.4 hours, reaching a concentration of 2.9X. The pot and system were shut down overnight, and cooled to room temperature and rose to atmospheric pressure. Figure 3-10 shows that on the second day, the pot temperature was relatively constant up to the 7.5Xconcentration (actual 7.3X), after which it began to rise. As expected due to the higher salt content, the temperature increased with concentration and the pressure drifted down, given the reduced availability of water in the evaporator pot. The contents of the evaporator pot 
were slightly turbid even at the boiling temperature, as shown in Figure 3-11. No foaming or unusual splattering was observed during the test.

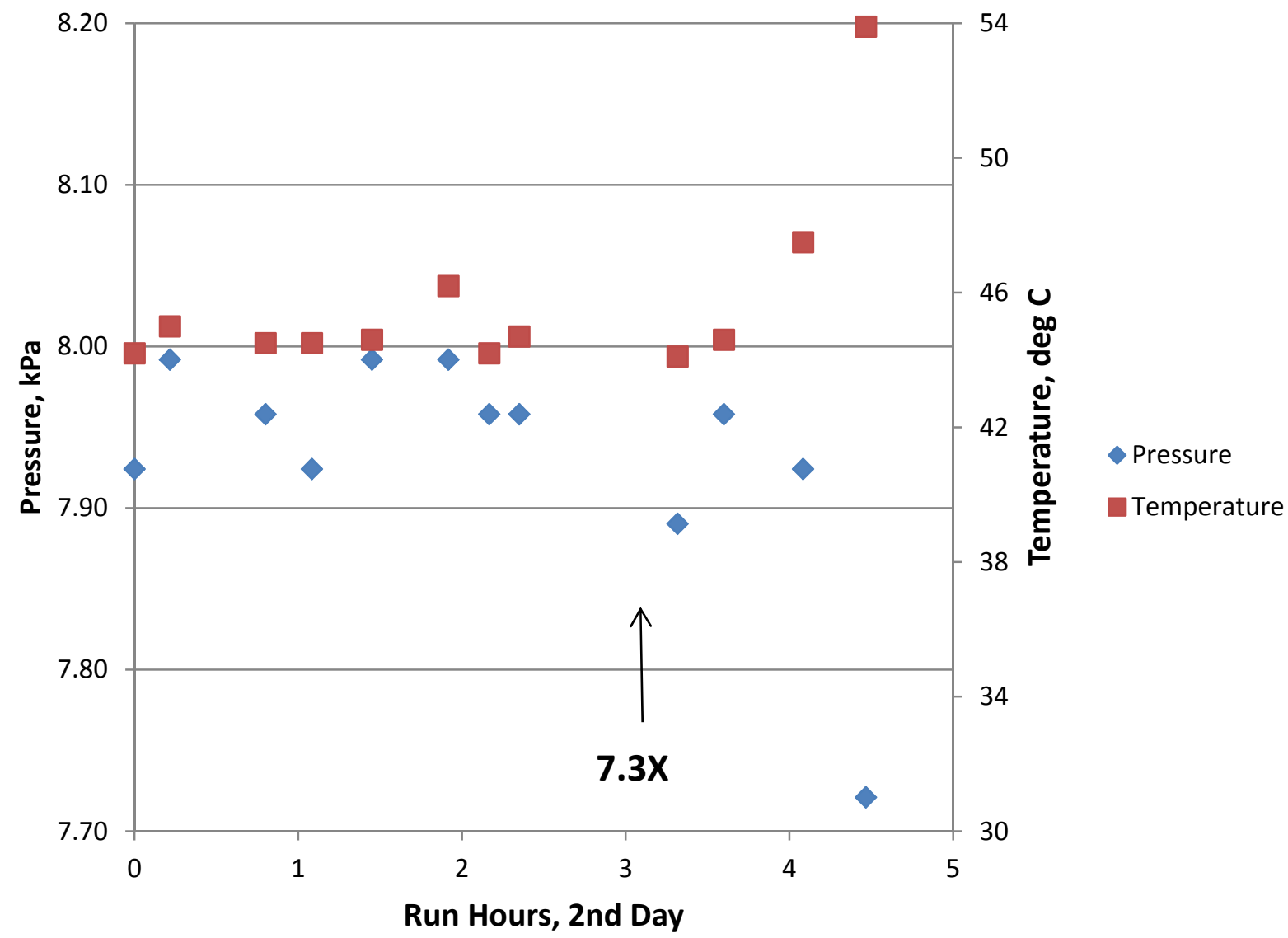

Figure 3-10. Evaporator Pressure and Temperature; $2^{\text {nd }}$ Day, Alkaline Campaign 


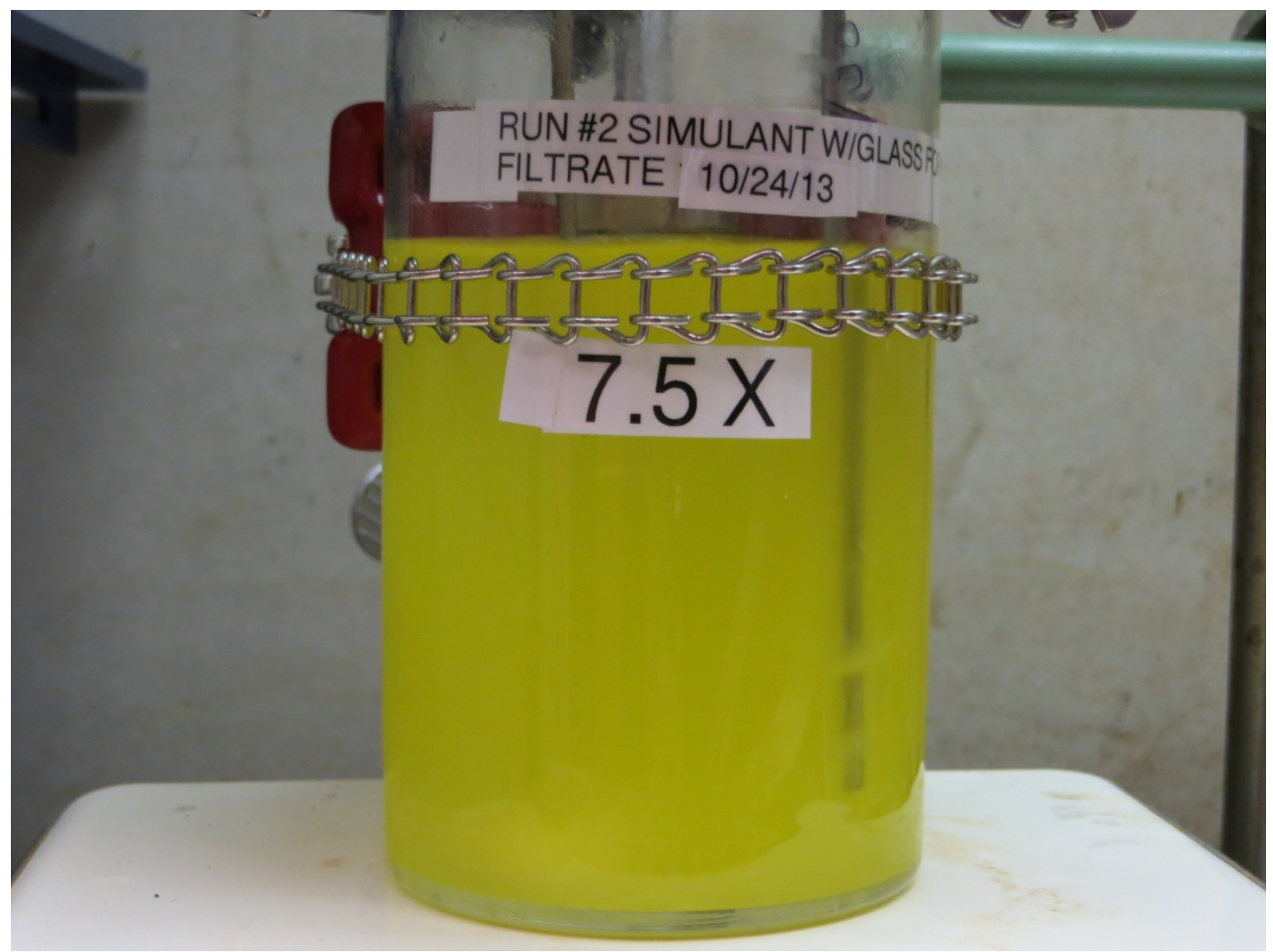

Figure 3-11 Image of Evaporator Pot at 7.5X, Alkaline Campaign

Figure 3-12 and 3-13 show elemental concentrations compared to the feed. Only soluble sulfate (measured as sulfur), lithium, and fluoride fail to remain soluble during boil down. The XRD for the solids from the 24X concentration sample, Figure 3-14, identified sodium fluorosulfate (Kogarkoite) and sodium fluoride as being present. The $24 \mathrm{X}$ sample was used versus the $30 \mathrm{X}$ sample for XRD for this campaign because the 30X sample was almost entirely crystalline solids with almost no free liquid, and it was desirable to examine which solids were preferentially formed. This 30X sample is obviously well beyond the desired operating condition for an evaporator, but was a desirable condition to examine for testing.

It is clear that sodium fluorosulfate (Kogarkoite) is a major solid that forms on concentration of this simulant at either $\mathrm{pH}$, and is a known scale former in the aluminum industry [Konigsberger, 2007]. At the alkaline $\mathrm{pH}$, the zinc, aluminum, boron, chromium, and potassium remain soluble because of their amphoteric nature, and the other species never reach their solubility limit. As observed during the neutral campaign, at high concentrations, the soluble species exceed the concentration factor of the pot, indicating that solids formation is significant. 


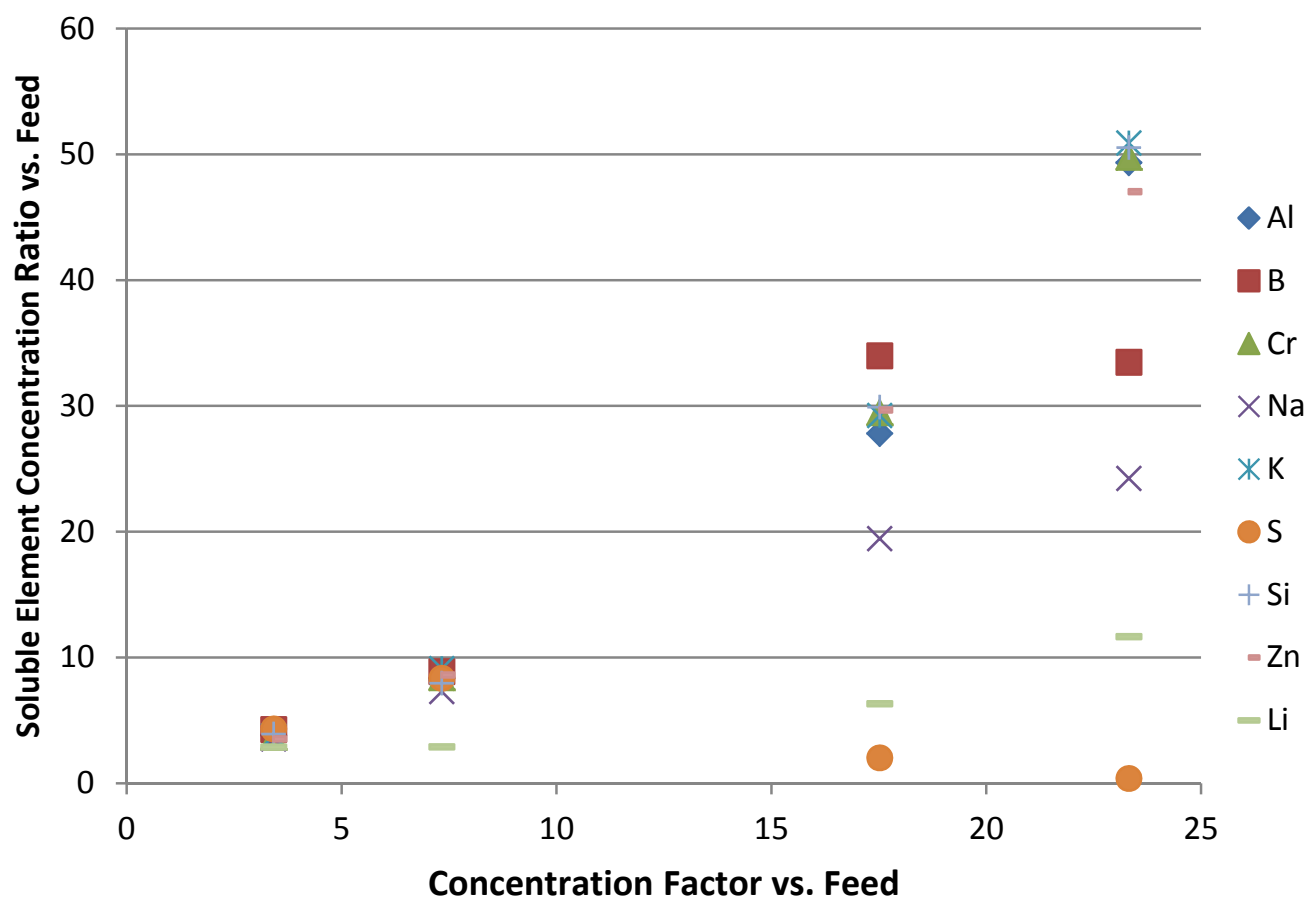

Figure 3-12. Soluble Element Concentration Ratios vs. Concentration, Alkaline Campaign

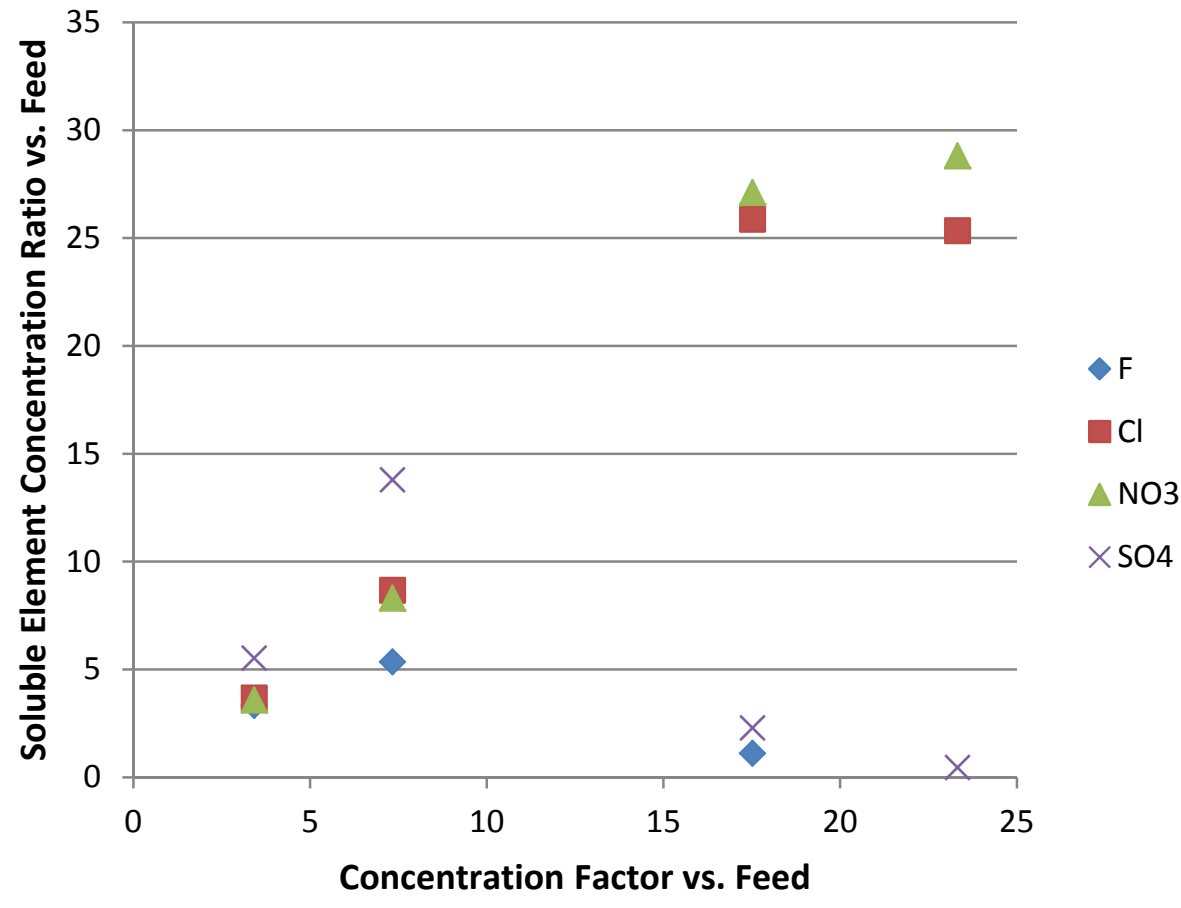

Figure 3-13. Soluble Anion Concentration Ratios vs. Concentration, Alkaline Campaign 


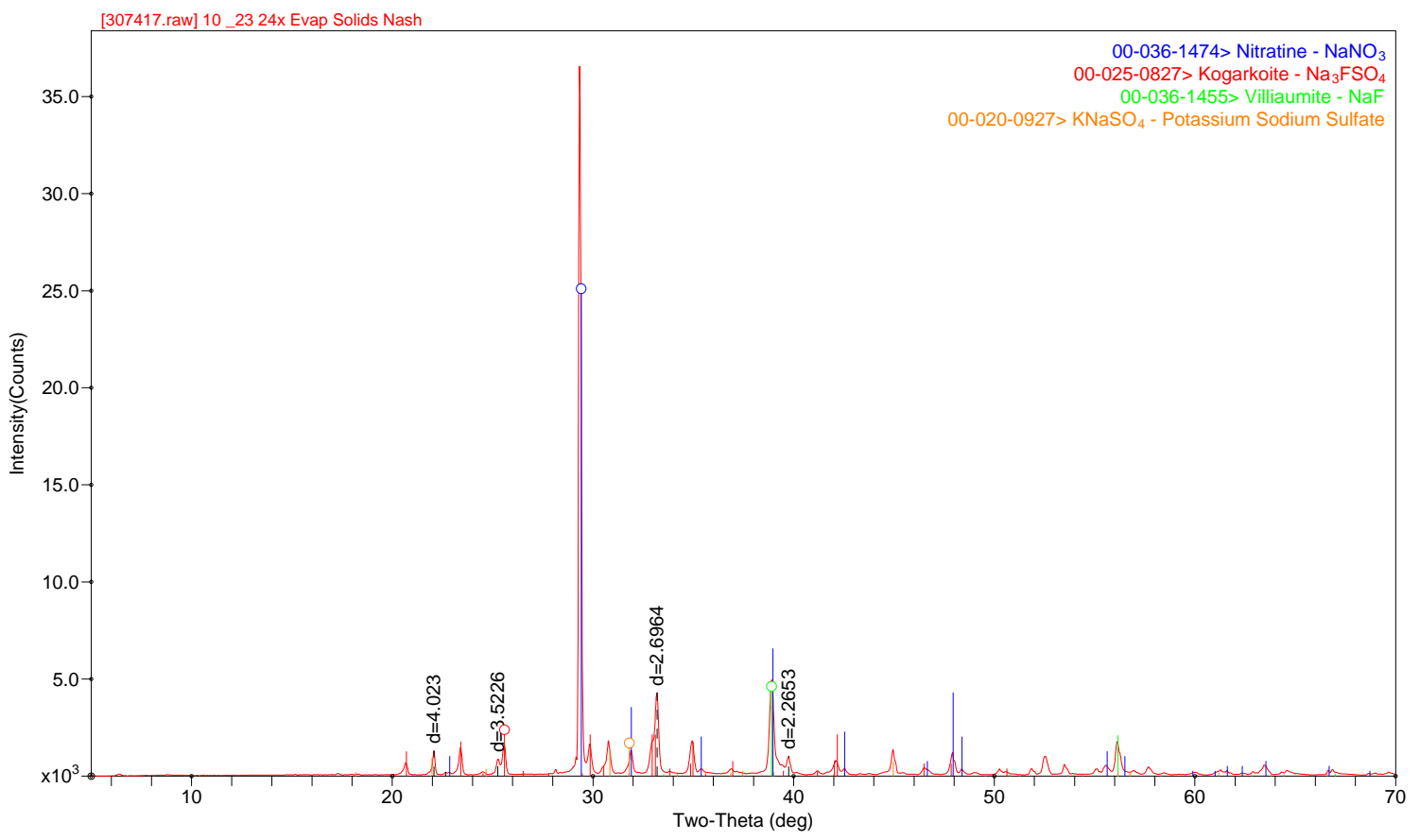

Figure 3-14. X-Ray Diffraction Data from 24X Sample, Alkaline Campaign

Stripping of ammonia at high $\mathrm{pH}$ was found, as expected. Figure 3-7 shows the composition of the condensate samples. Here ammonia stripping started high, in contrast to the first campaign, and remained roughly constant until near the end, when the pot was depleted in ammonia. The faster initial stripping was expected because the high $\mathrm{pH}$ converts the ammonium ion to ammonia, making it available for immediate stripping with the water vapor.

Similar to the neutral campaign, other than the final 30X samples, too little insoluble solids were present to accurately measure the wt $\%$ insoluble solids in the evaporator pot slurry, which has a detection limit of approximately $1 \mathrm{wt} \%$. As with the neutral campaign, in order to estimate the insoluble solids concentration, the samples ( $10 \mathrm{~g}$ ) were filtered, and the solids were extracted in $\sim 10 \mathrm{~mL}$ of water. Both the filtrate and the extract were then analyzed by ICP-AES and IC. Detailed results of the analyses are shown in Appendix B. To calculate the amount of a species in the insoluble solids versus in interstitial liquid, potassium was selected as the reference concentration, since it evidently remained soluble throughout both campaigns. The quantity of potassium present in the extract was used to calculate the amount of liquid absorbed onto the solids, and the mass fraction of each species assignable to the soluble portion was subtracted from the total. Results of the calculation for all species present that have one result at $>2 \mathrm{mg} / \mathrm{g}$ of slurry are shown in Table 3-3. Presumably, the fluoride and sulfate are present as either the sodium salts. It is likely that the absence of sufficient sodium ions to charge balance the anions is a result of analytical variability in measuring multiple samples with large amounts of sodium, which is much larger than the amount needed to charge balance the anions. The purpose of this analysis and calculation was to indicate when precipitated solids approach the $1 \mathrm{wt} \%$ limit. Small positive or negative numbers are statistically not distinguishable. The results indicate that 
the insoluble solids are $<1 \mathrm{wt} \%$ in all but the final, 30X sample. The final (30X) sample was thick slurry and did not yield filterable liquid.

Table 3-3 Calculated Quantity of Insoluble Species; Alkaline Campaign

\begin{tabular}{|c|c|c|c|c|}
\hline Concentration Factor & $\begin{array}{c}\mathrm{Na}^{+} \\
(\mathrm{mg} / \mathrm{g})\end{array}$ & $\begin{array}{c}F^{-} \\
(\mathrm{mg} / \mathrm{g})\end{array}$ & $\begin{array}{c}\mathrm{NO}_{3}^{-} \\
\text {(mg/g) }\end{array}$ & $\begin{array}{c}\mathrm{SO}_{4}^{-2} \\
(\mathrm{mg} / \mathrm{g})^{* * *}\end{array}$ \\
\hline Pre $7.5 \mathrm{X}$ & $-0.15^{*}$ & 0.073 & -0.052 & -0.05 \\
\hline $7.5 \mathrm{X}$ & 2.1 & 2.0 & 0.005 & 0.06 \\
\hline $18 \mathrm{X}$ & 0.51 & 7.4 & 35 & 0.18 \\
\hline $24 X$ & 53 & $* *$ & $* *$ & 37 \\
\hline 30X - insufficient liquid & & & & \\
\hline
\end{tabular}

*negative numbers are the result of variability of analysis

**analysis results were evidently in error

***calculated as sulfate from ICP-ES analysis of sulfur

An image of the evaporator pot samples from the alkaline campaign is shown in Figure 3-14, with the samples in increasing concentration left to right (except that the "pre-7.5X sample is actually $\sim 11 \mathrm{X}$ concentration). The liquid is yellow due to the chromate content. Other than the $24 \mathrm{X}$ and 30X samples, only a trace amount of insoluble white solids was visible. At 24X concentration, the bottle is approximately $15 \%$ full of insoluble white solids. At 30X concentration, there is no free liquid visible on top of the slurry.

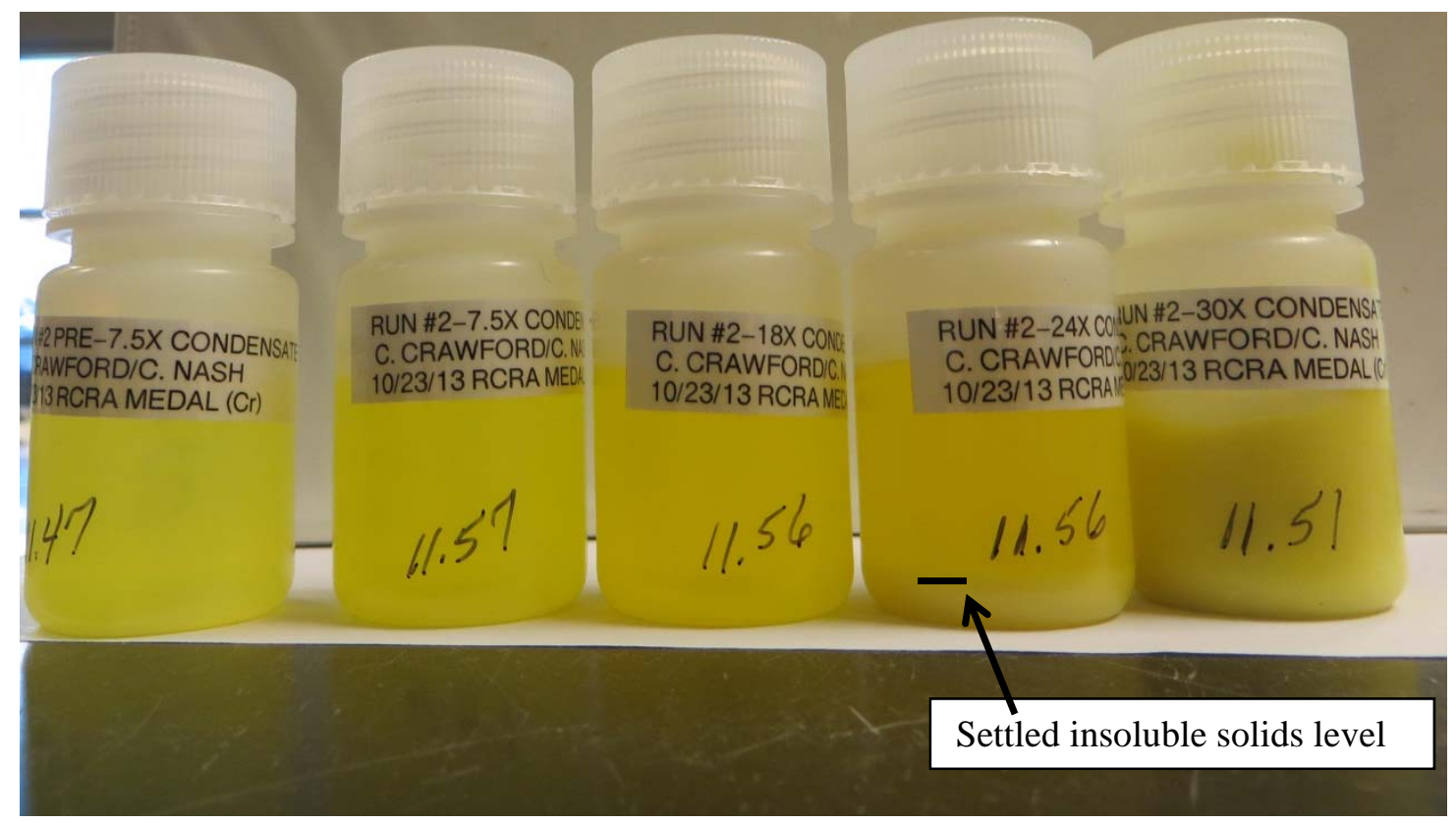

Figure 3-15 Image of Evaporator Pot Samples, Alkaline Campaign 


\subsection{Conclusions}

The objective of this evaporation development task is to evaluate concentration options for disposition of the Hanford LAW Off-Gas Condensate stream in the Tank Farms (Figures 1-2 and 1-3) or by other evaporation or concentration steps. This preliminary study examined two scenarios for disposition of this one projected waste composition. A key parameter is quantifying the achievable concentration factor and identifying the solids that form during the evaporation. Evaporation at neutral $\mathrm{pH}$ yielded very few insoluble solids until the concentration exceeded 24X. The solids were primarily kogarkoite $\left[\mathrm{Na}_{3}\left(\mathrm{SO}_{4}\right) \mathrm{F}\right]$. At 30X, substantial amounts of additional salts precipitated. The condensate contained approximately $200-400 \mathrm{mg} / \mathrm{L}$ of ammonia through the $7.5 \mathrm{X}$ concentration, but increased substantially at higher concentrations. Loss of ammonia to the condensate would have the effect of lowering the $\mathrm{pH}$ in the evaporator pot, which would cause corrosion concern issues. It is not known why the condensate was turbid. The presence of insoluble solids should not preclude evaporating this solution to at least 24X.

Evaporation at alkaline $\mathrm{pH}$ yielded more solids than at neutral $\mathrm{pH}$, with a thick slurry observed at $30 \mathrm{X}$ concentration. The major solid present at $24 \mathrm{X}$ was also kogarkoite. The condensate contained the majority of the ammonia, as expected. The presence of insoluble solids should not preclude evaporating this solution to at least $18 \mathrm{X}$.

Evaporation in an auxiliary evaporator at neutral $\mathrm{pH}$ would concentrate much of the ammonia/ammonium in the evaporator bottoms. Disposition of this stream would need to consider flammability and release of ammonia vapor in this concentrated stream. This partitioning of ammonia to the condensate would decrease the $\mathrm{pH}$ of the bottoms, increasing the corrosion potential. Since most of the ammonia is stripped when the solution is evaporated at alkaline $\mathrm{pH}$, this would not be as much of a concern if alkaline evaporation is planned. The ammonia content exceeded the design criteria for ETF at some point in both tests, so its management is key to successful disposition of this stream. Both scenarios need to consider the ammonia vapor management of the condensate.

Substantial foaming or splattering was not observed in the evaporator pot, indicating that the slurry is well behaved and does not have viscosity issues.

Overall, evaporation seemed to work fairly effectively, without any significant process issues observed at this early stage of testing. Minimal solids were formed in the evaporator bottoms until a substantial fraction of liquid was removed, indicating that evaporation could minimize storage volume issues. Achievable concentration factors without significant insoluble solids were $17 \mathrm{X}$ at alkaline $\mathrm{pH}$, and $23 \mathrm{X}$ at neutral $\mathrm{pH}$. At this stage, corrosion potential from halides and sulfate appears as the most challenging impact. However, evaporation of this stream, without its separate treatment and disposal, does not achieve the long-term goal of decreasing the quantity of LAW glass or the mission duration of WTP.

\subsection{Future Work}

Evaporation appears to be a plausible method for concentrating this waste stream, although the corrosion impacts have not been examined. If evaporation is selected as a possible treatment path, the conditions need to be selected (alkaline or neutral $\mathrm{pH}$ ), and the glass former solids 
(which were removed prior to evaporation for this test) need to be dispositioned. Although the ammonia content in the condensate during alkaline evaporation and late in the neutral evaporation exceeds the maximum design criteria for ETF, it is otherwise expected to be compatible, although more comprehensive analyses are needed once a path and conditions are selected. Radionuclides are expected to remain primarily in the evaporator bottoms, but evaluations are needed to determine the fate and impacts of ${ }^{129} \mathrm{I}$. Corrosion of the evaporator and connected equipment would also need to be evaluated. Further testing of evaporation is needed to examine the range of compositions expected from the LAW facility, now that the insoluble solids that have the highest propensity to precipitate have been identified.

An alternate calculation is needed of the composition of the LAW Off-Gas Condensate if the LAW facility operates without the HLW or Pretreatment systems operating. This scenario would yield lower halide and sulfate concentrations in the LAW Off-Gas Condensate because both the HLW melter Off-Gas Condensate and sludge leaching/washing liquids gets mixed with the aqueous waste and pretreated to become LAW feed. Since those HLW-originated streams will contain halide and sulfate ions, the projected LAW Off-Gas Condensate concentrations are higher. To examine the composition of the LAW Off-Gas Condensate from a scenario without HLW or Pretreatment facility operations, a new model run of that scenario would be needed that could then be used to generate an alternate simulant for testing. Note, however, that the ${ }^{99} \mathrm{Tc}$ content would likely be unchanged, since it is mostly soluble and therefore associated with LAW, and would continue to vaporize from the melter. Similarly, a pretreatment process would presumably remove ${ }^{137} \mathrm{Cs}$ to the same concentration as planned for the WTP Pretreatment facility, and it would therefore be at the same concentration in the Off-Gas Condensate. Carryover of particulates and glass formers would probably not be considerably different either. Better modeling and measurement tools are needed to predict and control the carryover. Minimizing carryover of glass formers would have the benefit of decreasing the potential for aluminosilicatebased scale formation in an evaporator.

Although only small amounts of insoluble solids were observed when this stream was evaporated, it is expected that this could be problematic for using RO for this stream. Typically, it is vital to avoid conditions that lead to any insoluble solids in most RO equipment configurations. Some equipment designs are more tolerant of insoluble solids, but would still likely have lower throughput than a stream that did not form solids. Also, this stream was an average expected concentration, and a maximum case would likely have more solids. Designs that are more tolerant of insoluble solids need to be investigated to determine feasibility. In the event that the LAW facility operates without the HLW or Pretreatment facilities online, and with low halide tank wastes, using a RO is likely still plausible as an interim concentration method. In either case, testing would be needed to verify performance. 
SRNL-STI-2013-00713

Revision 0

\subsection{References}

Abramowitz, H., Brandys, M., Cecil, R., D’Angelo, N., Matlack, K.S., Muller, I.S., Pegg, I.L., Callow, R.A., Joseph, I., Technetium Retention in WTP LAW Glass with Recycle Flow-Sheet: DM10 Melter Testing, VSL-12R2640-1, Rev. 0, RPP-54130, September, 2012.

Arakali, V.S., Stone, I., 2012 WTP Tank Utilization Assessment, 24590-WTP-RPT-PE12-001, Rev. 0, March 26, 2012

Belsher, J.D., Empey, P.A., Hohl, T.M., Kirkbride, R.A., Ritari, J.S., West, E.B., Bergmann, L., M., Wells, M.N., Hanford Tank Waste Operations Simulator (HTWOS) Version 7.4 Model Design Document, RPP-17152, Rev. 7, November, 2012

Callaway, W.S., Results of Boildown Study on Liquid Waste Retrieved from Tank 241AW-106 in March, 2009, WRPS-1000136, January, 2010

Crawford, T.W., Conner, J.M., Johnson, M.E., Mann, F.M., Unterreiner, B.J., Williamson, R.D., Lueck, K.J., McNamar, E.A., Secondary Waste Management Strategy for Early Low Activity Waste Treatment, RPP-RPT-37924, July, 2008.

CRC Handbook of Chemistry and Physics, 56 ${ }^{\text {th }}$ edition, CRC Press, Cleveland, OH (1975)

Edgemon, G.L., Anda, V.S., Dahl, M.M., Piekarski, C.M., Corrosion Assessment of Effluent Treatment Facility (ETF) for Secondary Liquid Waste Treatment (SLWT) Project, RPP-50821, September, 2012

Halgren, D.L., Liquid Waste Processing Facilities Waste Acceptance Criteria, HNF-3172, Rev. 6, October, 2012

Hobbs, D.T., Improved Strontium and Actinide Separations Modified Monosodium Titanate Final Report of FY2008 Testing Activities, SRNL-STI-2008-00390, December, 2008.

Icenhower, J.P., Qafoku, N.P., Martin, W.J., Zachara, J.M., The Geochemistry of Technetium: A Summary of the Behavior of an Artificial Element in the Natural Environment, PNNL-18139, December 2008

Icenhower, J.P., Qafoku, N.P., Martin, W.J., Zachara, J.M., The Biogeochemistry of Technetium: A review of the behavior of an Element in the Natural Environment, October 2010

Jo, J., Tank Farms Waste Transfer Compatibility Program, HNF-SD-WM-OCD-015, Rev. 29, March, 2013 
Konigsberger, E.H., Hefter, G., May, P.M., chapter 15, Solubility of Solids in Bayer Liquors, Development and Applications in Solubility, T.M., Letcher, ed., Royal Society of Chemistry, 2007

Lueck, K.J., Mcnamar, E.A., Low Activity Waste (LAW) Facility Secondary Waste to Effluent Treatment Facility (ETF) Treatability Evaluation, HNF-37718, May, 2008

Mann, F.M., Puigh, R.J., Khaleel, R., Finfrock, S., McGrail, B.P., Bacon, D.H., Serne, R.J., Risk Assessment Supporting the Decision on the Initial Selection of Supplemental ILAW Technologies, RPP-17675, Rev. 0, September 29, 2003

Matlack, K.S., Gong, W., Diener, G., Bardakci, T., Brandys, M., Pegg, I.L., Final Report; Summary of DM1200 SBS History and Performance, VSL-06R6410-2, August, 2, 2006

Mattigod, S.V., Serne, R.J., Fryxell, G.E., Selection and Testing of "Getters" for Adsorption of Iodine-129 and Technetium-99: A Review, PNNL-14208, September, 2003

May, T.H., Gehner, P.D., Stegen, G., Hymas, J., Pajunen, A., Sexton, R., Ramsey, A., Secondary Waste - ETF Pre-Conceptual Engineering Study, RPP-RPT-43588, December 22, 2009

McCabe, D.J., Wilmarth, W.R., Nash, C.A., Waste Treatment Technology Process Development Plan for Hanford Waste Treatment Plant Low Activity Waste Recycle, SRNL-STI-2013-00351, July, 2013

Reid, R., Prausnitz, J., and Sherwood, T., "The Properties of Gases and Liquids”, third edition, McGraw-Hill, New York, NY, (1977).

Roberson, C. E., Hem, J. D., Solubility of Aluminum in the Presence of Hydroxide, Fluoride, and Sulfate - Chemistry of Aluminum in Natural Waters, Geological Survey Water-Supply Paper 1827-C, United States Government Printing Office, Washington : 1969.

RPP-RPT-50967, Secondary Liquid Waste Treatment Project (T3W08) Conceptual Design Report

Wilmarth, W.R., Mills, J.T., Dukes, V.H., Burkhalter, P.U., Characterization of PostCleaning Solids Samples from the 2H Evaporator Pot, WSRC-TR-2003-00570, December 5, 2003

Wilmarth, W.R., McCabe, D.J., Nash, C.A., Task Technical and Quality Assurance Plan for Developing a Flowsheet for Off-Gas Process Liquids from the Hanford Low Activity Waste Vitrification Process, SRNL-RP-2013-00135, March, 2013 
Yanochko, R.M., Corcoran, C., Golcar, G.R., Johnson, P., Nolan, L.M., Pajunen, A., Submerged Bed Scrubber Condensate Disposal Preconceptual Engineering Study, RPPRPT-52321, September, 2012

SVF-2732, 2013, “SVF-2732 MMR-13-008 data Case 1 rev 0.xlsx,” Rev. 0, Washington River Protection Solutions, LLC, Richland, Washington. 


\section{Appendix A. SVF-2732 Case 1 Mission Averaged Composition; First LAW and Second} LAW

\begin{tabular}{|c|c|c|c|c|}
\hline \multicolumn{5}{|c|}{ SBS + WESP Averaged composition; Case 1 LAW + 2nd LAW } \\
\hline & & $\begin{array}{l}\text { Average } \\
\text { Case } 1 \text { LAW } \\
+ \text { 2nd LAW }\end{array}$ & \begin{tabular}{|l} 
Maximum \\
Case 1 LAW + \\
2nd LAW
\end{tabular} & $\begin{array}{l}\text { Minimum } \\
\text { Case } 1 \text { LAW } \\
+ \text { 2nd LAW }\end{array}$ \\
\hline & Liters & 328149 & 770855 & 51286 \\
\hline 106-Ru & $\mathrm{Ci} / \mathrm{L}$ & $3.53 \mathrm{E}-10$ & $1.87 \mathrm{E}-09$ & 3.17E-13 \\
\hline $113 m-C d$ & $\mathrm{Ci} / \mathrm{L}$ & $4.90 \mathrm{E}-08$ & $1.16 \mathrm{E}-07$ & $1.44 \mathrm{E}-08$ \\
\hline $125-\mathrm{Sb}$ & $\mathrm{Ci} / \mathrm{L}$ & $1.12 \mathrm{E}-06$ & $5.56 \mathrm{E}-06$ & $1.90 \mathrm{E}-08$ \\
\hline $126-S n$ & $\mathrm{Ci} / \mathrm{L}$ & $6.22 \mathrm{E}-09$ & $1.91 \mathrm{E}-08$ & $6.55 \mathrm{E}-10$ \\
\hline $129-1$ & $\mathrm{Ci} / \mathrm{L}$ & $2.58 \mathrm{E}-08$ & $5.01 \mathrm{E}-08$ & 9.41E-09 \\
\hline $134-C s$ & $\mathrm{Ci} / \mathrm{L}$ & $9.61 \mathrm{E}-11$ & $5.17 \mathrm{E}-10$ & $1.62 \mathrm{E}-12$ \\
\hline $137-C s$ & $\mathrm{Ci} / \mathrm{L}$ & $5.21 \mathrm{E}-06$ & $1.16 \mathrm{E}-05$ & $1.80 \mathrm{E}-06$ \\
\hline $137 \mathrm{~m}-\mathrm{Ba}$ & $\mathrm{Ci} / \mathrm{L}$ & $4.92 \mathrm{E}-06$ & $1.09 \mathrm{E}-05$ & $1.70 \mathrm{E}-06$ \\
\hline $14-C$ & $\mathrm{Ci} / \mathrm{L}$ & $0.00 \mathrm{E}+00$ & $0.00 \mathrm{E}+00$ & $0.00 \mathrm{E}+00$ \\
\hline 151-Sm & $\mathrm{Ci} / \mathrm{L}$ & $8.66 \mathrm{E}-06$ & $2.67 \mathrm{E}-05$ & $3.75 \mathrm{E}-07$ \\
\hline 152-Eu & $\mathrm{Ci} / \mathrm{L}$ & $1.63 \mathrm{E}-09$ & $5.53 \mathrm{E}-09$ & $4.32 \mathrm{E}-11$ \\
\hline 154-Eu & $\mathrm{Ci} / \mathrm{L}$ & $4.50 \mathrm{E}-08$ & $1.86 \mathrm{E}-07$ & 3.11E-09 \\
\hline 155-Eu & $\mathrm{Ci} / \mathrm{L}$ & $2.42 \mathrm{E}-08$ & $9.64 \mathrm{E}-08$ & $1.12 \mathrm{E}-09$ \\
\hline 226-Ra & $\mathrm{Ci} / \mathrm{L}$ & $3.53 \mathrm{E}-12$ & $8.56 \mathrm{E}-12$ & $7.26 \mathrm{E}-13$ \\
\hline $227-A c$ & $\mathrm{Ci} / \mathrm{L}$ & $2.63 \mathrm{E}-12$ & $3.64 \mathrm{E}-11$ & $-1.11 \mathrm{E}-10$ \\
\hline 228-Ra & $\mathrm{Ci} / \mathrm{L}$ & $3.85 \mathrm{E}-09$ & $1.47 \mathrm{E}-08$ & $3.03 \mathrm{E}-10$ \\
\hline 229-Th & $\mathrm{Ci} / \mathrm{L}$ & $2.40 \mathrm{E}-12$ & $1.05 \mathrm{E}-11$ & $6.50 \mathrm{E}-14$ \\
\hline 231-Pa & $\mathrm{Ci} / \mathrm{L}$ & $4.68 \mathrm{E}-11$ & $2.03 \mathrm{E}-10$ & $7.25 \mathrm{E}-12$ \\
\hline 232-Th & $\mathrm{Ci} / \mathrm{L}$ & $5.18 \mathrm{E}-12$ & $2.44 \mathrm{E}-11$ & $2.24 \mathrm{E}-13$ \\
\hline $232-U$ & $\mathrm{Ci} / \mathrm{L}$ & $9.93 \mathrm{E}-12$ & $2.52 \mathrm{E}-11$ & $1.94 \mathrm{E}-12$ \\
\hline $233-U$ & $\mathrm{Ci} / \mathrm{L}$ & $5.63 \mathrm{E}-10$ & $2.19 \mathrm{E}-09$ & $9.08 \mathrm{E}-11$ \\
\hline $234-U$ & $\mathrm{Ci} / \mathrm{L}$ & $2.85 \mathrm{E}-10$ & $8.16 \mathrm{E}-10$ & $9.06 \mathrm{E}-11$ \\
\hline $235-U$ & $\mathrm{Ci} / \mathrm{L}$ & $1.19 \mathrm{E}-11$ & $3.27 \mathrm{E}-11$ & $3.76 \mathrm{E}-12$ \\
\hline $236-U$ & $\mathrm{Ci} / \mathrm{L}$ & $8.25 \mathrm{E}-12$ & $4.59 \mathrm{E}-11$ & $2.62 \mathrm{E}-12$ \\
\hline 237-Np & $\mathrm{Ci} / \mathrm{L}$ & $4.73 \mathrm{E}-10$ & $1.41 \mathrm{E}-09$ & $1.46 \mathrm{E}-10$ \\
\hline 238-Pu & $\mathrm{Ci} / \mathrm{L}$ & $1.68 \mathrm{E}-09$ & $3.58 \mathrm{E}-09$ & $5.94 \mathrm{E}-10$ \\
\hline $238-U$ & $\mathrm{Ci} / \mathrm{L}$ & $2.81 \mathrm{E}-10$ & $7.22 \mathrm{E}-10$ & $8.54 \mathrm{E}-11$ \\
\hline 239-Pu & $\mathrm{Ci} / \mathrm{L}$ & $3.13 \mathrm{E}-08$ & $5.67 \mathrm{E}-08$ & $7.55 \mathrm{E}-09$ \\
\hline 240-Pu & $\mathrm{Ci} / \mathrm{L}$ & $6.63 \mathrm{E}-09$ & $1.26 \mathrm{E}-08$ & $2.51 \mathrm{E}-09$ \\
\hline 241-Am & $\mathrm{Ci} / \mathrm{L}$ & $2.32 \mathrm{E}-07$ & $1.50 \mathrm{E}-06$ & $2.14 \mathrm{E}-08$ \\
\hline 241-Pu & $\mathrm{Ci} / \mathrm{L}$ & 5.51E-08 & $1.49 \mathrm{E}-07$ & $2.01 \mathrm{E}-08$ \\
\hline $242-\mathrm{Cm}$ & $\mathrm{Ci} / \mathrm{L}$ & $3.43 \mathrm{E}-10$ & $8.75 \mathrm{E}-10$ & $6.38 \mathrm{E}-11$ \\
\hline 242-Pu & $\mathrm{Ci} / \mathrm{L}$ & $4.93 \mathrm{E}-13$ & $1.14 \mathrm{E}-12$ & $1.95 \mathrm{E}-13$ \\
\hline 243-Am & $\mathrm{Ci} / \mathrm{L}$ & $1.19 \mathrm{E}-10$ & $7.85 \mathrm{E}-10$ & $9.64 \mathrm{E}-12$ \\
\hline 243-Cm & $\mathrm{Ci} / \mathrm{L}$ & $3.05 \mathrm{E}-11$ & $1.50 \mathrm{E}-10$ & $4.79 \mathrm{E}-12$ \\
\hline 244-Cm & $\mathrm{Ci} / \mathrm{L}$ & $6.71 \mathrm{E}-10$ & $3.35 \mathrm{E}-09$ & $1.05 \mathrm{E}-10$ \\
\hline $3-\mathrm{H}$ & $\mathrm{Ci} / \mathrm{L}$ & $0.00 \mathrm{E}+00$ & $0.00 \mathrm{E}+00$ & $0.00 \mathrm{E}+00$ \\
\hline 59-Ni & $\mathrm{Ci} / \mathrm{L}$ & 7.11E-09 & $3.55 \mathrm{E}-08$ & $2.41 \mathrm{E}-09$ \\
\hline $60-\mathrm{Co}$ & $\mathrm{Ci} / \mathrm{L}$ & $1.65 \mathrm{E}-08$ & 7.09E-08 & $3.69 E-09$ \\
\hline 63-Ni & $\mathrm{Ci} / \mathrm{L}$ & $5.99 \mathrm{E}-07$ & $2.45 \mathrm{E}-06$ & $2.16 \mathrm{E}-07$ \\
\hline 79-Se & $\mathrm{Ci} / \mathrm{L}$ & $9.10 \mathrm{E}-08$ & $1.49 \mathrm{E}-07$ & $3.55 \mathrm{E}-08$ \\
\hline
\end{tabular}

Note: 227-Ac minimum is negative in the output, evidently for unknown calculation errors 
SRNL-STI-2013-00713

Revision 0

\begin{tabular}{|c|c|c|c|c|}
\hline & & \begin{tabular}{|l|} 
Average \\
Case 1 LAW \\
+ 2nd LAW
\end{tabular} & $\begin{array}{l}\text { Maximum } \\
\text { Case } 1 \text { LAW + } \\
\text { 2nd LAW }\end{array}$ & $\begin{array}{l}\text { Minimum } \\
\text { Case 1 LAW } \\
+ \text { 2nd LAW }\end{array}$ \\
\hline $90-\mathrm{Sr}$ & $\mathrm{Ci} / \mathrm{L}$ & $2.61 \mathrm{E}-05$ & $1.07 \mathrm{E}-04$ & $1.03 \mathrm{E}-05$ \\
\hline $90-Y$ & $\mathrm{Ci} / \mathrm{L}$ & $2.61 \mathrm{E}-05$ & 1.07E-04 & 1.03E-05 \\
\hline $93-\mathrm{Zr}$ & $\mathrm{Ci} / \mathrm{L}$ & $9.33 \mathrm{E}-10$ & 2.64E-09 & $1.47 \mathrm{E}-10$ \\
\hline $93 \mathrm{~m}-\mathrm{Nb}$ & $\mathrm{Ci} / \mathrm{L}$ & $1.05 \mathrm{E}-07$ & 2.16E-07 & $3.07 \mathrm{E}-08$ \\
\hline 99-Tc & $\mathrm{Ci} / \mathrm{L}$ & $4.15 \mathrm{E}-05$ & $6.11 \mathrm{E}-05$ & $1.99 \mathrm{E}-05$ \\
\hline $\mathrm{Ag}+$ & $\mathrm{g} / \mathrm{L}$ & $1.46 \mathrm{E}-05$ & $3.95 \mathrm{E}-05$ & $6.43 \mathrm{E}-07$ \\
\hline $\mathrm{Al}(\mathrm{OH}) 3$ & $\mathrm{~g} / \mathrm{L}$ & $0.00 \mathrm{E}+00$ & $0.00 \mathrm{E}+00$ & $0.00 \mathrm{E}+00$ \\
\hline $\mathrm{Al}(\mathrm{OH}) 4-$ & $\mathrm{g} / \mathrm{L}$ & $1.01 \mathrm{E}-01$ & $1.35 \mathrm{E}-01$ & $4.97 \mathrm{E}-02$ \\
\hline $\mathrm{Al}+3$ & $\mathrm{~g} / \mathrm{L}$ & $0.00 \mathrm{E}+00$ & $0.00 \mathrm{E}+00$ & $0.00 \mathrm{E}+00$ \\
\hline $\mathrm{AlOOH}$ & $\mathrm{g} / \mathrm{L}$ & $0.00 \mathrm{E}+00$ & $0.00 \mathrm{E}+00$ & $0.00 \mathrm{E}+00$ \\
\hline As+5 & $\mathrm{g} / \mathrm{L}$ & $6.98 \mathrm{E}-04$ & $1.73 \mathrm{E}-03$ & 3.87E-05 \\
\hline $\mathrm{B}+3$ & $\mathrm{~g} / \mathrm{L}$ & $4.22 \mathrm{E}-05$ & 1.03E-04 & 2.83E-06 \\
\hline $\mathrm{Ba}+2$ & $\mathrm{~g} / \mathrm{L}$ & $6.20 \mathrm{E}-06$ & $1.39 \mathrm{E}-05$ & $5.83 \mathrm{E}-07$ \\
\hline $\mathrm{Be}+2$ & $\mathrm{~g} / \mathrm{L}$ & $1.35 \mathrm{E}-06$ & $7.46 \mathrm{E}-06$ & 7.87E-08 \\
\hline $\mathrm{Bi}+3$ & $\mathrm{~g} / \mathrm{L}$ & $2.62 \mathrm{E}-04$ & 4.66E-04 & $7.81 \mathrm{E}-05$ \\
\hline $\mathrm{C} 10 \mathrm{H} 12 \mathrm{~N} 2 \mathrm{O} 8-4$ & $\mathrm{~g} / \mathrm{L}$ & $0.00 \mathrm{E}+00$ & $0.00 \mathrm{E}+00$ & $0.00 \mathrm{E}+00$ \\
\hline C10H15N2O7-3 & $\mathrm{g} / \mathrm{L}$ & $0.00 \mathrm{E}+00$ & $0.00 \mathrm{E}+00$ & $0.00 \mathrm{E}+00$ \\
\hline $\mathrm{C} 12 \mathrm{H} 27 \mathrm{O} 4 \mathrm{P}$ & $\mathrm{g} / \mathrm{L}$ & $0.00 \mathrm{E}+00$ & $0.00 \mathrm{E}+00$ & $0.00 \mathrm{E}+00$ \\
\hline $\mathrm{C} 13 \mathrm{H} 28$ & $\mathrm{~g} / \mathrm{L}$ & $0.00 \mathrm{E}+00$ & $0.00 \mathrm{E}+00$ & $0.00 \mathrm{E}+00$ \\
\hline $\mathrm{C} 2 \mathrm{Cl} 4$ & $\mathrm{~g} / \mathrm{L}$ & $0.00 \mathrm{E}+00$ & $0.00 \mathrm{E}+00$ & $0.00 \mathrm{E}+00$ \\
\hline $\mathrm{C} 2 \mathrm{H} 3 \mathrm{O} 2-$ & $\mathrm{g} / \mathrm{L}$ & $0.00 \mathrm{E}+00$ & $0.00 \mathrm{E}+00$ & $0.00 \mathrm{E}+00$ \\
\hline C2H3O3- & $\mathrm{g} / \mathrm{L}$ & $0.00 \mathrm{E}+00$ & $0.00 \mathrm{E}+00$ & $0.00 \mathrm{E}+00$ \\
\hline $\mathrm{C} 2 \mathrm{HCl} 3$ & $\mathrm{~g} / \mathrm{L}$ & $0.00 \mathrm{E}+00$ & $0.00 \mathrm{E}+00$ & $0.00 \mathrm{E}+00$ \\
\hline C2O4-2 & $\mathrm{g} / \mathrm{L}$ & $0.00 \mathrm{E}+00$ & $0.00 \mathrm{E}+00$ & $0.00 \mathrm{E}+00$ \\
\hline $\mathrm{C} 3 \mathrm{H} 6 \mathrm{O}$ & $\mathrm{g} / \mathrm{L}$ & $0.00 \mathrm{E}+00$ & $0.00 \mathrm{E}+00$ & $0.00 \mathrm{E}+00$ \\
\hline C4H10O & $\mathrm{g} / \mathrm{L}$ & $0.00 \mathrm{E}+00$ & $0.00 \mathrm{E}+00$ & $0.00 \mathrm{E}+00$ \\
\hline $\mathrm{C} 4 \mathrm{H} 8 \mathrm{O}$ & $\mathrm{g} / \mathrm{L}$ & $0.00 \mathrm{E}+00$ & $0.00 \mathrm{E}+00$ & $0.00 \mathrm{E}+00$ \\
\hline $\mathrm{C} 5 \mathrm{H} 5 \mathrm{~N}$ & $\mathrm{~g} / \mathrm{L}$ & $0.00 \mathrm{E}+00$ & $0.00 \mathrm{E}+00$ & $0.00 \mathrm{E}+00$ \\
\hline $\mathrm{C} 6 \mathrm{H} 5 \mathrm{NO} 2$ & $\mathrm{~g} / \mathrm{L}$ & $0.00 \mathrm{E}+00$ & $0.00 \mathrm{E}+00$ & $0.00 \mathrm{E}+00$ \\
\hline C6H5O7-3 & $\mathrm{g} / \mathrm{L}$ & $0.00 \mathrm{E}+00$ & $0.00 \mathrm{E}+00$ & $0.00 \mathrm{E}+00$ \\
\hline $\mathrm{C} 6 \mathrm{H} 6$ & $\mathrm{~g} / \mathrm{L}$ & $0.00 \mathrm{E}+00$ & $0.00 \mathrm{E}+00$ & $0.00 \mathrm{E}+00$ \\
\hline $\mathrm{C} 7 \mathrm{H} 6 \mathrm{~N} 2 \mathrm{O} 4$ & $\mathrm{~g} / \mathrm{L}$ & $0.00 \mathrm{E}+00$ & $0.00 \mathrm{E}+00$ & $0.00 \mathrm{E}+00$ \\
\hline $\mathrm{C} 7 \mathrm{H} 8 \mathrm{O}$ & $\mathrm{g} / \mathrm{L}$ & $0.00 \mathrm{E}+00$ & $0.00 \mathrm{E}+00$ & $0.00 \mathrm{E}+00$ \\
\hline $\mathrm{Ca}+2$ & $\mathrm{~g} / \mathrm{L}$ & $1.28 \mathrm{E}-04$ & $2.16 \mathrm{E}-04$ & 4.95E-05 \\
\hline $\mathrm{Cd}+2$ & $\mathrm{~g} / \mathrm{L}$ & $2.41 \mathrm{E}-05$ & $9.60 \mathrm{E}-05$ & $3.10 \mathrm{E}-06$ \\
\hline $\mathrm{Ce}+3$ & $\mathrm{~g} / \mathrm{L}$ & $1.75 \mathrm{E}-03$ & 4.05E-03 & 2.30E-05 \\
\hline $\mathrm{CH} 2 \mathrm{Cl} 2$ & $\mathrm{~g} / \mathrm{L}$ & $0.00 \mathrm{E}+00$ & $0.00 \mathrm{E}+00$ & $0.00 \mathrm{E}+00$ \\
\hline $\mathrm{CHCl} 3$ & $\mathrm{~g} / \mathrm{L}$ & $0.00 \mathrm{E}+00$ & $0.00 \mathrm{E}+00$ & $0.00 \mathrm{E}+00$ \\
\hline CHO2- & $\mathrm{g} / \mathrm{L}$ & $0.00 \mathrm{E}+00$ & $0.00 \mathrm{E}+00$ & $0.00 \mathrm{E}+00$ \\
\hline $\mathrm{Cl}-$ & $\mathrm{g} / \mathrm{L}$ & $9.50 \mathrm{E}-01$ & $1.13 \mathrm{E}+00$ & $3.88 \mathrm{E}-01$ \\
\hline $\mathrm{CN}-$ & $\mathrm{g} / \mathrm{L}$ & 4.93E-06 & $8.54 \mathrm{E}-05$ & $8.85 \mathrm{E}-09$ \\
\hline $\mathrm{Co}+3$ & $\mathrm{~g} / \mathrm{L}$ & 7.35E-06 & $1.82 \mathrm{E}-05$ & $1.48 \mathrm{E}-06$ \\
\hline $\mathrm{CO}-2$ & $\mathrm{~g} / \mathrm{L}$ & $0.00 \mathrm{E}+00$ & $0.00 \mathrm{E}+00$ & $0.00 \mathrm{E}+00$ \\
\hline
\end{tabular}


SRNL-STI-2013-00713

Revision 0

\begin{tabular}{|c|c|c|c|c|}
\hline & & $\begin{array}{l}\text { Average } \\
\text { Case 1 LAW } \\
+ \text { 2nd LAW }\end{array}$ & $\begin{array}{l}\text { Maximum } \\
\text { Case } 1 \text { LAW + } \\
\text { 2nd LAW }\end{array}$ & $\begin{array}{l}\text { Minimum } \\
\text { Case } 1 \text { LAW } \\
+ \text { 2nd LAW }\end{array}$ \\
\hline $\mathrm{Cr}(\mathrm{OH}) 4-$ & $\mathrm{g} / \mathrm{L}$ & $0.00 \mathrm{E}+00$ & $0.00 \mathrm{E}+00$ & $0.00 \mathrm{E}+00$ \\
\hline $\mathrm{Cr}$ (TOTAL) & $\mathrm{g} / \mathrm{L}$ & $0.00 \mathrm{E}+00$ & $0.00 \mathrm{E}+00$ & $0.00 E+00$ \\
\hline CrO4-2 & $\mathrm{g} / \mathrm{L}$ & $2.04 \mathrm{E}-01$ & $3.09 \mathrm{E}-01$ & $7.60 \mathrm{E}-02$ \\
\hline $\mathrm{CrOOH}$ & $\mathrm{g} / \mathrm{L}$ & $0.00 \mathrm{E}+00$ & $0.00 \mathrm{E}+00$ & $0.00 \mathrm{E}+00$ \\
\hline Cs+ & $\mathrm{g} / \mathrm{L}$ & $1.29 \mathrm{E}-07$ & $2.56 \mathrm{E}-07$ & $4.69 \mathrm{E}-08$ \\
\hline $\mathrm{Cu}+2$ & $\mathrm{~g} / \mathrm{L}$ & $8.17 \mathrm{E}-05$ & $4.59 \mathrm{E}-04$ & $4.73 \mathrm{E}-06$ \\
\hline \begin{tabular}{|l}
$\mathrm{F}-$ \\
\end{tabular} & $\mathrm{g} / \mathrm{L}$ & $1.45 \mathrm{E}+00$ & $3.70 \mathrm{E}+00$ & $5.39 \mathrm{E}-01$ \\
\hline $\mathrm{Fe}+3$ & $\mathrm{~g} / \mathrm{L}$ & $1.47 \mathrm{E}-04$ & $4.33 \mathrm{E}-04$ & 3.57E-05 \\
\hline $\mathrm{H}+$ & $\mathrm{g} / \mathrm{L}$ & $3.04 \mathrm{E}-02$ & $1.56 \mathrm{E}-01$ & $2.79 \mathrm{E}-02$ \\
\hline $\mathrm{H} 2 \mathrm{O}$ & $\mathrm{g} / \mathrm{L}$ & $9.98 \mathrm{E}+02$ & $9.99 \mathrm{E}+02$ & $9.98 \mathrm{E}+02$ \\
\hline \begin{tabular}{|l}
$\mathrm{H} 2 \mathrm{O} 2$ \\
\end{tabular} & $\mathrm{~g} / \mathrm{L}$ & $0.00 \mathrm{E}+00$ & $0.00 \mathrm{E}+00$ & $0.00 \mathrm{E}+00$ \\
\hline $\mathrm{Hg}+2$ & $\mathrm{~g} / \mathrm{L}$ & $0.00 \mathrm{E}+00$ & $0.00 \mathrm{E}+00$ & $0.00 \mathrm{E}+00$ \\
\hline $\mathrm{K}+$ & $\mathrm{g} / \mathrm{L}$ & $1.15 \mathrm{E}-01$ & 8.17E-01 & $3.58 \mathrm{E}-02$ \\
\hline $\mathrm{La}+3$ & $\mathrm{~g} / \mathrm{L}$ & $3.94 \mathrm{E}-06$ & $1.13 \mathrm{E}-05$ & $1.03 \mathrm{E}-07$ \\
\hline \begin{tabular}{|l}
$\mathrm{Li+}$ \\
\end{tabular} & $\mathrm{g} / \mathrm{L}$ & $5.30 \mathrm{E}-06$ & $1.66 \mathrm{E}-05$ & $3.18 \mathrm{E}-07$ \\
\hline \begin{tabular}{|l|}
$\mathrm{Mg}+2$ \\
\end{tabular} & $\mathrm{~g} / \mathrm{L}$ & $4.32 \mathrm{E}-07$ & $1.25 \mathrm{E}-06$ & $2.29 \mathrm{E}-08$ \\
\hline $\mathrm{Mn}+4$ & $\mathrm{~g} / \mathrm{L}$ & $3.64 \mathrm{E}-05$ & $1.04 \mathrm{E}-04$ & $1.15 \mathrm{E}-05$ \\
\hline $\mathrm{MnO} 2$ & $\mathrm{~g} / \mathrm{L}$ & $0.00 \mathrm{E}+00$ & $0.00 \mathrm{E}+00$ & $0.00 \mathrm{E}+00$ \\
\hline \begin{tabular}{|l}
$\mathrm{MnO} 4-$ \\
\end{tabular} & $\mathrm{g} / \mathrm{L}$ & $0.00 \mathrm{E}+00$ & $0.00 \mathrm{E}+00$ & $0.00 \mathrm{E}+00$ \\
\hline $\mathrm{Mo+6}$ & $\mathrm{g} / \mathrm{L}$ & $1.42 \mathrm{E}-04$ & $3.57 \mathrm{E}-04$ & $6.46 \mathrm{E}-06$ \\
\hline $\mathrm{Na}+$ & $\mathrm{g} / \mathrm{L}$ & $2.29 \mathrm{E}+00$ & $2.03 \mathrm{E}+00$ & $1.17 \mathrm{E}+00$ \\
\hline $\mathrm{Nd}+3$ & $\mathrm{~g} / \mathrm{L}$ & $2.05 \mathrm{E}-05$ & $6.10 \mathrm{E}-05$ & $1.20 \mathrm{E}-06$ \\
\hline \begin{tabular}{|l|}
$\mathrm{NH} 3$ \\
\end{tabular} & $\mathrm{~g} / \mathrm{L}$ & $4.38 \mathrm{E}-03$ & $3.47 \mathrm{E}-01$ & $1.21 \mathrm{E}-05$ \\
\hline \begin{tabular}{|l|}
$\mathrm{NH} 4+$ \\
\end{tabular} & $\mathrm{g} / \mathrm{L}$ & $1.51 \mathrm{E}+00$ & $1.63 \mathrm{E}+00$ & $4.98 \mathrm{E}-01$ \\
\hline $\mathrm{Ni}+2$ & $\mathrm{~g} / \mathrm{L}$ & $2.89 \mathrm{E}-04$ & $1.12 \mathrm{E}-03$ & $7.20 \mathrm{E}-05$ \\
\hline \begin{tabular}{|l}
$\mathrm{NO} 2-$ \\
\end{tabular} & $\mathrm{g} / \mathrm{L}$ & $1.07 \mathrm{E}-02$ & $2.01 \mathrm{E}-01$ & $1.79 E-306$ \\
\hline NO3- & $\mathrm{g} / \mathrm{L}$ & $5.53 \mathrm{E}+00$ & $6.66 \mathrm{E}+00$ & 8.57E-01 \\
\hline $\mathrm{O}(\mathrm{BOUND})$ & $\mathrm{g} / \mathrm{L}$ & 8.64E-05 & $2.10 \mathrm{E}-04$ & $3.93 \mathrm{E}-06$ \\
\hline $\mathrm{OH}(\mathrm{BOUND})$ & $\mathrm{g} / \mathrm{L}$ & $0.00 \mathrm{E}+00$ & $0.00 \mathrm{E}+00$ & $0.00 \mathrm{E}+00$ \\
\hline \begin{tabular}{|l}
$\mathrm{OH}-$ \\
\end{tabular} & $\mathrm{g} / \mathrm{L}$ & $2.20 \mathrm{E}-07$ & $1.08 \mathrm{E}-06$ & $0.00 \mathrm{E}+00$ \\
\hline $\mathrm{Pb}+2$ & $\mathrm{~g} / \mathrm{L}$ & $3.47 \mathrm{E}-04$ & $1.16 \mathrm{E}-03$ & $1.25 \mathrm{E}-04$ \\
\hline $\mathrm{Pd}+2$ & $\mathrm{~g} / \mathrm{L}$ & $1.95 \mathrm{E}-05$ & $1.88 \mathrm{E}-04$ & $7.60 \mathrm{E}-08$ \\
\hline \begin{tabular}{|l|}
$\mathrm{PO} 4-3$ \\
\end{tabular} & $\mathrm{~g} / \mathrm{L}$ & $2.15 \mathrm{E}-02$ & $4.92 \mathrm{E}-02$ & $1.20 \mathrm{E}-02$ \\
\hline $\mathrm{Pr}+3$ & $\mathrm{~g} / \mathrm{L}$ & $1.80 \mathrm{E}-06$ & $1.07 \mathrm{E}-05$ & $6.23 \mathrm{E}-09$ \\
\hline $\mathrm{Pu}+4$ & $\mathrm{~g} / \mathrm{L}$ & $0.00 \mathrm{E}+00$ & $0.00 \mathrm{E}+00$ & $0.00 \mathrm{E}+00$ \\
\hline $\mathrm{Rb}+$ & $\mathrm{g} / \mathrm{L}$ & $1.17 \mathrm{E}-06$ & $3.30 \mathrm{E}-05$ & $3.42 \mathrm{E}-09$ \\
\hline $\mathrm{Rh}+3$ & $\mathrm{~g} / \mathrm{L}$ & $7.25 \mathrm{E}-06$ & $5.88 \mathrm{E}-05$ & $2.44 \mathrm{E}-08$ \\
\hline $\mathrm{Ru}+3$ & $\mathrm{~g} / \mathrm{L}$ & $7.04 \mathrm{E}-06$ & $1.25 \mathrm{E}-04$ & $1.25 \mathrm{E}-07$ \\
\hline$S b+5$ & $\mathrm{~g} / \mathrm{L}$ & $7.06 \mathrm{E}-04$ & $1.35 \mathrm{E}-03$ & $5.70 \mathrm{E}-05$ \\
\hline $\mathrm{Se}+6$ & $\mathrm{~g} / \mathrm{L}$ & $2.90 \mathrm{E}-03$ & $5.24 \mathrm{E}-03$ & 7.06E-04 \\
\hline $\mathrm{Si}+4$ & $\mathrm{~g} / \mathrm{L}$ & $1.03 \mathrm{E}-03$ & $1.66 \mathrm{E}-03$ & $3.29 \mathrm{E}-04$ \\
\hline SO4-2 & $\mathrm{g} / \mathrm{L}$ & $2.34 \mathrm{E}+00$ & $4.37 \mathrm{E}+00$ & $1.22 \mathrm{E}-03$ \\
\hline $\mathrm{Sr}+2$ & $\mathrm{~g} / \mathrm{L}$ & $2.32 \mathrm{E}-04$ & $4.73 \mathrm{E}-03$ & $6.46 \mathrm{E}-06$ \\
\hline
\end{tabular}


SRNL-STI-2013-00713

Revision 0

\begin{tabular}{|l|r|r|r|r|}
\hline & & $\begin{array}{l}\text { Average } \\
\text { Case 1 LAW } \\
+2 \text { 2nd LAW }\end{array}$ & $\begin{array}{l}\text { Maximum } \\
\text { Case 1 LAW + } \\
\text { 2nd LAW }\end{array}$ & $\begin{array}{l}\text { Minimum } \\
\text { Case 1 LAW } \\
+2 \text { 2nd LAW }\end{array}$ \\
\hline $\mathrm{Ta}+5$ & $\mathrm{~g} / \mathrm{L}$ & $6.51 \mathrm{E}-06$ & $4.03 \mathrm{E}-05$ & $2.25 \mathrm{E}-08$ \\
\hline $\mathrm{T}+7$ & $\mathrm{~g} / \mathrm{L}$ & $0.00 \mathrm{E}+00$ & $0.00 \mathrm{E}+00$ & $0.00 \mathrm{E}+00$ \\
\hline $\mathrm{Te}+6$ & $\mathrm{~g} / \mathrm{L}$ & $2.37 \mathrm{E}-04$ & $1.20 \mathrm{E}-03$ & $4.49 \mathrm{E}-07$ \\
\hline $\mathrm{T}+4$ & $\mathrm{~g} / \mathrm{L}$ & $3.82 \mathrm{E}-08$ & $1.67 \mathrm{E}-07$ & $1.14 \mathrm{E}-09$ \\
\hline $\mathrm{Ti}+4$ & $\mathrm{~g} / \mathrm{L}$ & $9.61 \mathrm{E}-07$ & $2.36 \mathrm{E}-06$ & $4.74 \mathrm{E}-08$ \\
\hline $\mathrm{T}+3$ & $\mathrm{~g} / \mathrm{L}$ & $6.83 \mathrm{E}-04$ & $1.83 \mathrm{E}-03$ & $6.13 \mathrm{E}-06$ \\
\hline $\mathrm{TOC}$ & $\mathrm{g} / \mathrm{L}$ & $0.00 \mathrm{E}+00$ & $0.00 \mathrm{E}+00$ & $0.00 \mathrm{E}+00$ \\
\hline $\mathrm{U}(\mathrm{TOTAL})$ & $\mathrm{g} / \mathrm{L}$ & $0.00 \mathrm{E}+00$ & $0.00 \mathrm{E}+00$ & $0.00 \mathrm{E}+00$ \\
\hline $\mathrm{V}+5$ & $\mathrm{~g} / \mathrm{L}$ & $1.75 \mathrm{E}-05$ & $4.61 \mathrm{E}-05$ & $1.57 \mathrm{E}-06$ \\
\hline $\mathrm{W}+6$ & $\mathrm{~g} / \mathrm{L}$ & $2.31 \mathrm{E}-05$ & $1.11 \mathrm{E}-04$ & $2.87 \mathrm{E}-08$ \\
\hline $\mathrm{Y}+3$ & $\mathrm{~g} / \mathrm{L}$ & $3.18 \mathrm{E}-06$ & $1.84 \mathrm{E}-05$ & $1.56 \mathrm{E}-08$ \\
\hline $\mathrm{Zn}+2$ & $\mathrm{~g} / \mathrm{L}$ & $3.06 \mathrm{E}-06$ & $1.50 \mathrm{E}-05$ & $1.43 \mathrm{E}-07$ \\
\hline $\mathrm{Zr}+4$ & $\mathrm{~g} / \mathrm{L}$ & $5.70 \mathrm{E}-06$ & $3.43 \mathrm{E}-05$ & $1.70 \mathrm{E}-07$ \\
\hline
\end{tabular}




\section{Appendix B - Evaporator Pot Sample Analysis Results}

All analyses performed on duplicate samples (A, B)

SBS Control (initial) samples are the initial evaporator feed samples.

Evaporator pot slurries ( $\sim 10 \mathrm{~g})$ were filtered. Filtrate was analyzed. Solids were extracted with $10 \mathrm{~mL}$ of deionized water, and analyzed.

Table B-1 Mass of evaporator pot slurry filtered and mass of deionized water for extract dissolution; neutral campaign

\begin{tabular}{|l|c|c|}
\hline Sample i.d. & $\begin{array}{l}\text { Sample Slurry Applied to } \\
\text { filter pad (g) }\end{array}$ & $\begin{array}{l}\text { Mass DI water in Extract } \\
\text { sample bottle (g) }\end{array}$ \\
\hline pre-7.5X & 9.9983 & 10.0303 \\
\hline $7.5 \mathrm{X}$ & 10.0256 & 10.0019 \\
\hline $18 \mathrm{X}$ & 10.0099 & 10.0127 \\
\hline $24 \mathrm{X}$ & 10.0089 & 10.0013 \\
\hline $30 \mathrm{X}$ & 10.0597 & 10.0166 \\
\hline
\end{tabular}

Table B-2 Mass of evaporator pot slurry filtered and mass of deionized water for extract dissolution; alkaline campaign

\begin{tabular}{|l|c|c|}
\hline Sample i.d. & $\begin{array}{l}\text { Sample Slurry Applied to } \\
\text { filter pad (g) }\end{array}$ & $\begin{array}{l}\text { Mass DI water in Extract } \\
\text { sample bottle (g) }\end{array}$ \\
\hline pre-7.5X & 10.0017 & 10.0284 \\
\hline $7.5 \mathrm{X}$ & 10.2412 & 10.0149 \\
\hline $18 \mathrm{X}$ & 11.2501 & 10.0039 \\
\hline $24 \mathrm{X}$ & 11.0608 & 10.0107 \\
\hline $30 \mathrm{X}$ & Insufficient liquid & -- \\
\hline
\end{tabular}


Table B-3. Elemental and anion analysis for neutral $\mathrm{pH}$ evaporation campaign (initial feed control sample, filtered evaporator pot samples, dissolved solid extract samples)

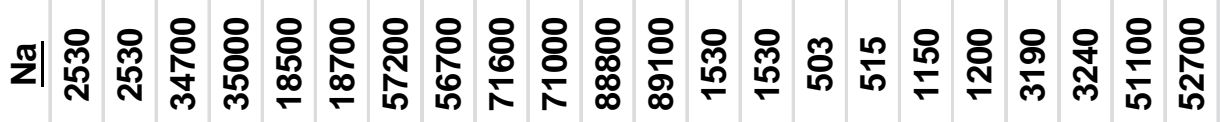

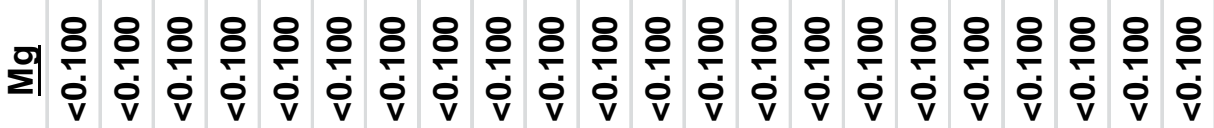

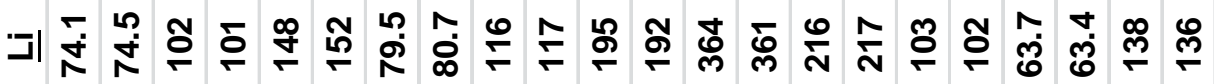

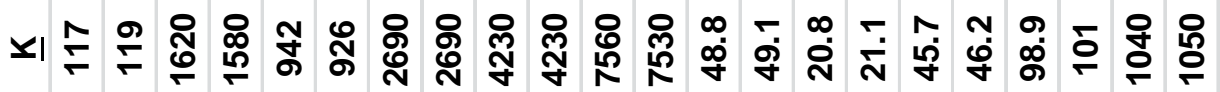

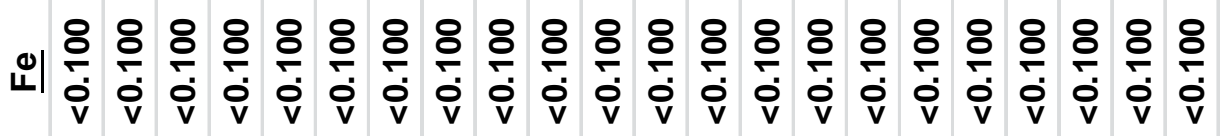

ঢ)

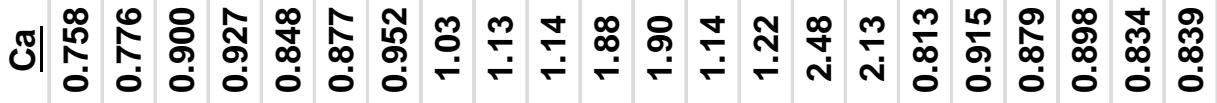

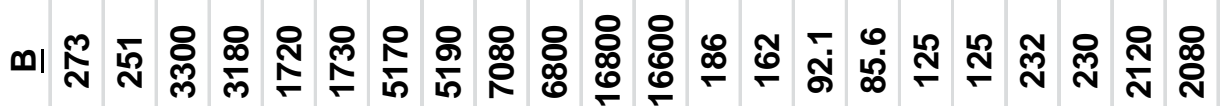

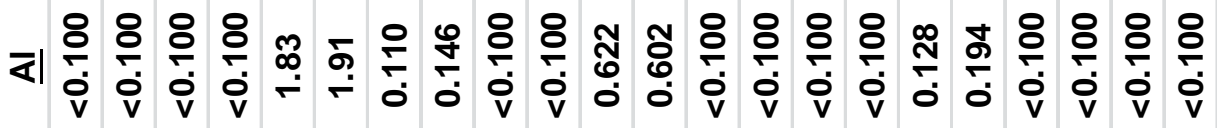

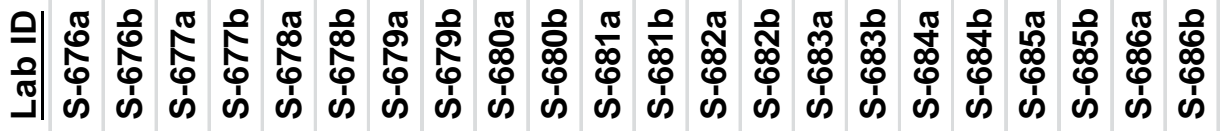

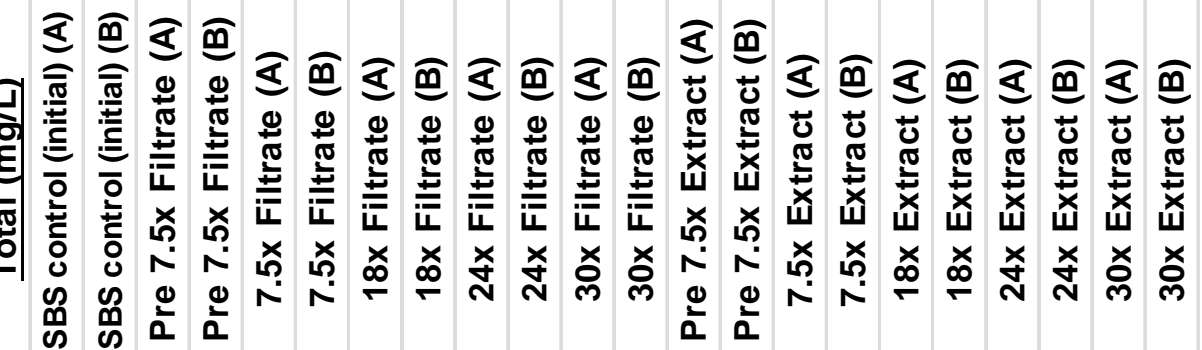


Table B-3 continued. Elemental and anion analysis for neutral pH evaporation campaign (initial feed control samples, filtered evaporator pot samples, dissolved solid extract samples)

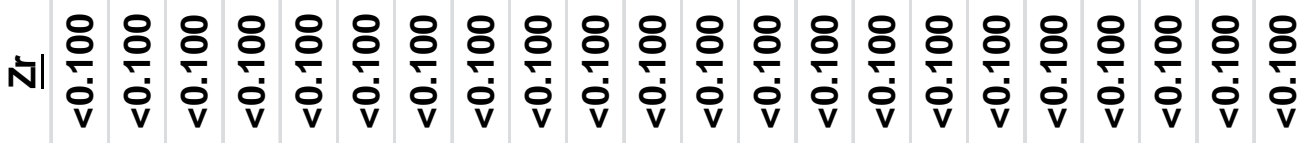

N|

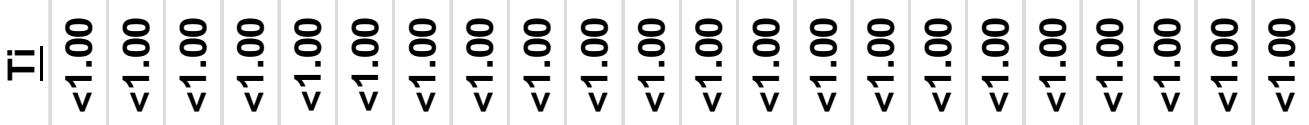

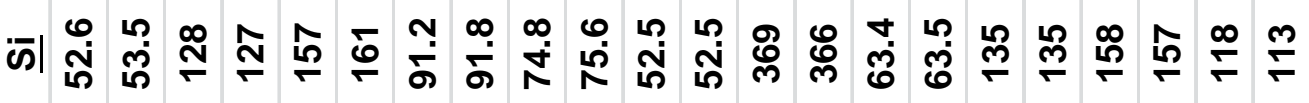

ง।

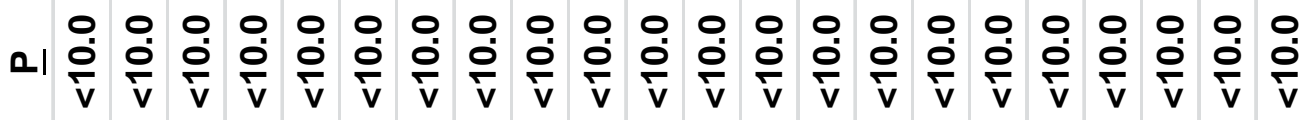

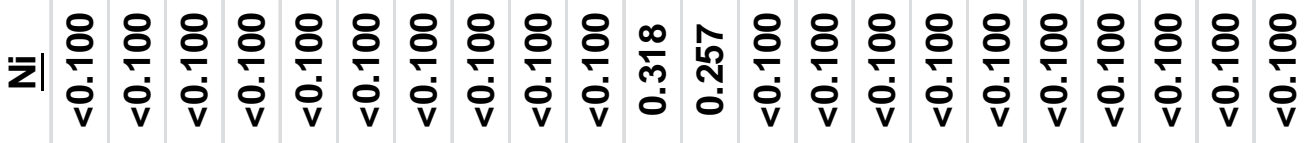

$\widetilde{\underline{\Xi}} \widetilde{\Xi}$

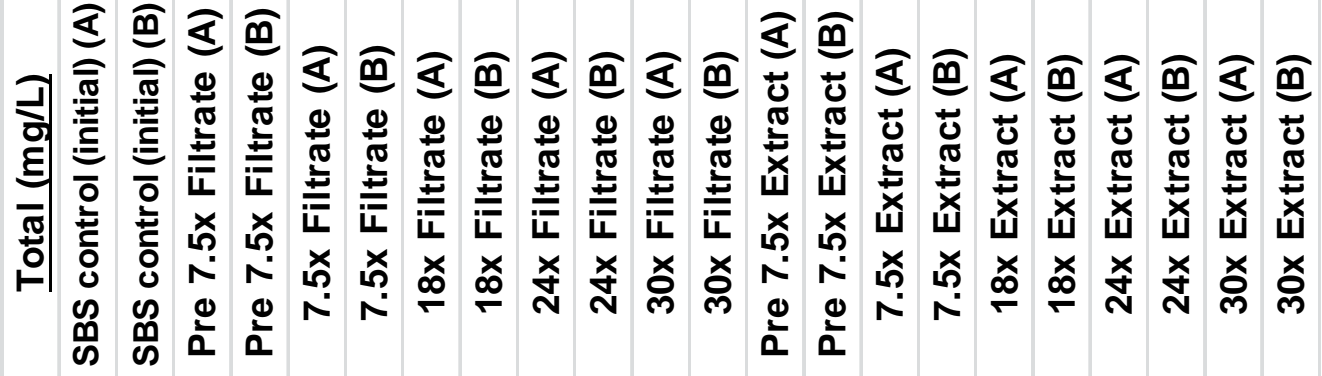


Table B-3 continued. Elemental and anion analysis for neutral pH evaporation campaign (initial feed control samples, filtered evaporator pot samples, dissolved solid extract samples)

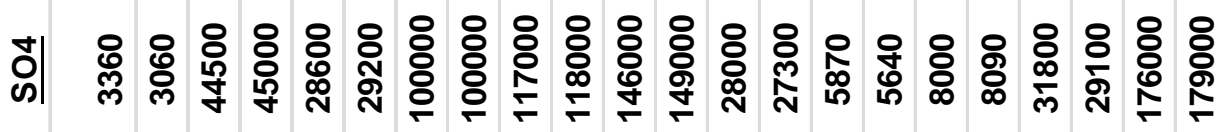

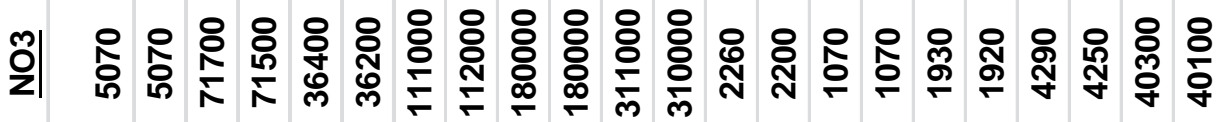

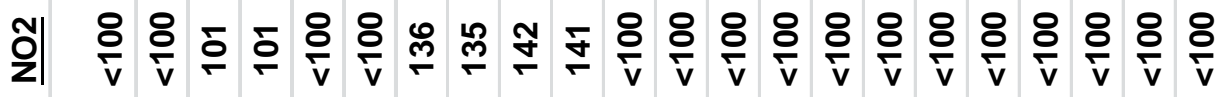

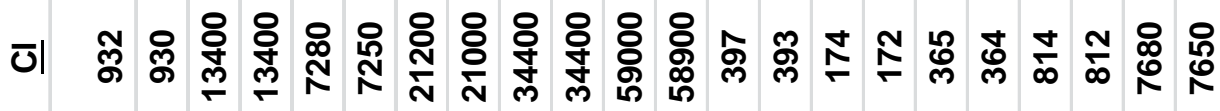

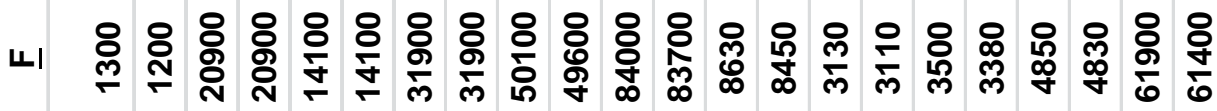

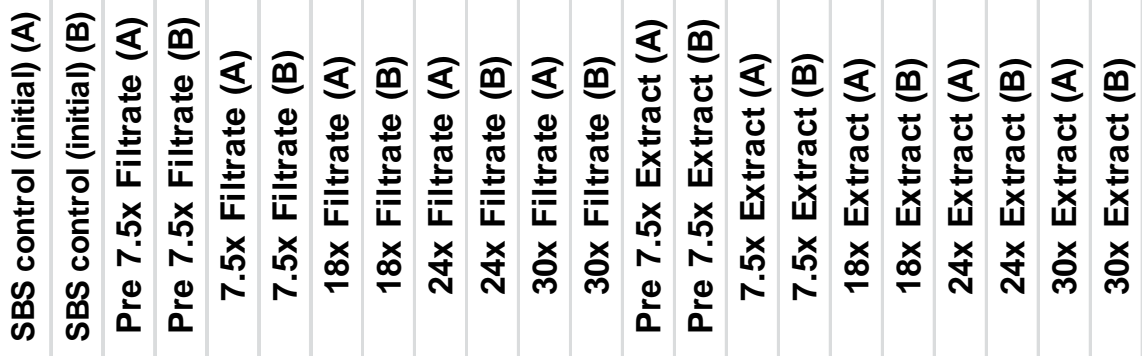


Table B-4. Elemental and anion analysis for alkaline $\mathrm{pH}$ evaporation campaign (initial feed control samples, filtered evaporator pot samples, dissolved solid extract samples)

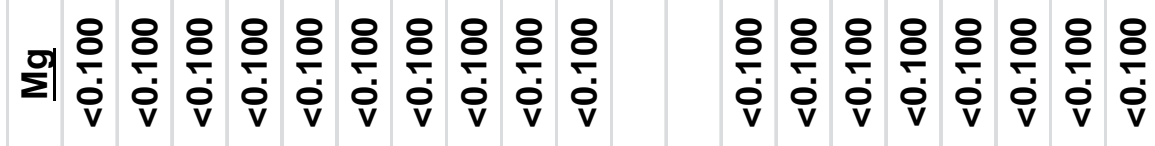

ت 棺

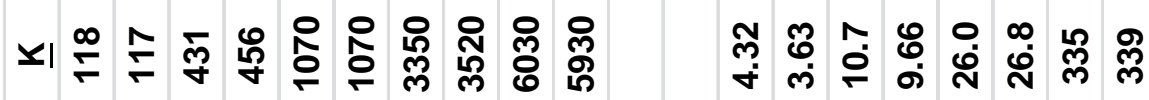

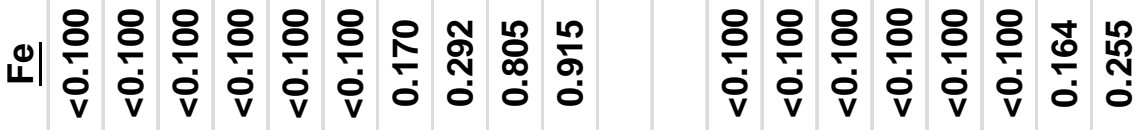

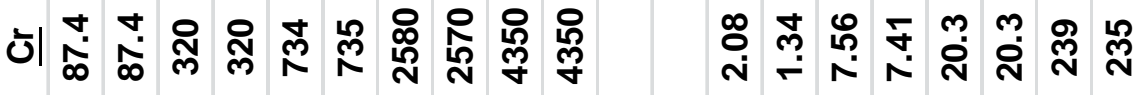

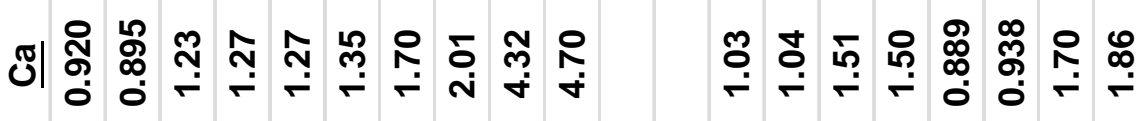

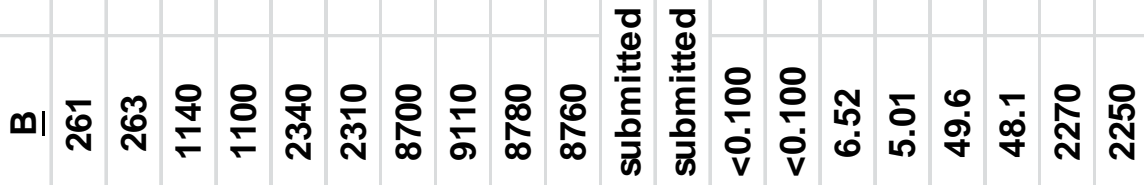
ㅎํ

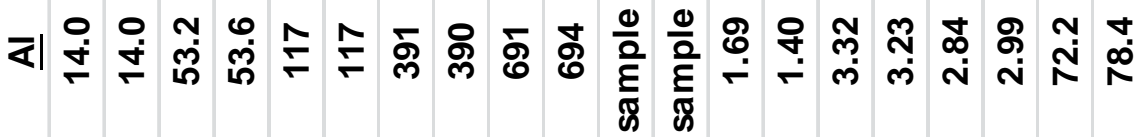

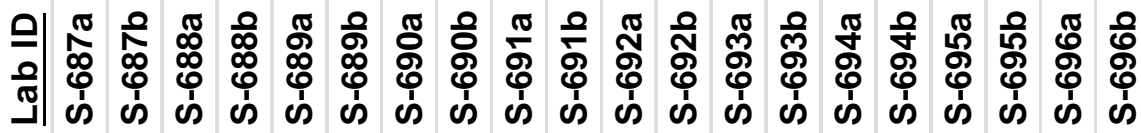

$\widetilde{\S} \widetilde{\underline{\Xi}} \widetilde{\underline{\Xi}}$

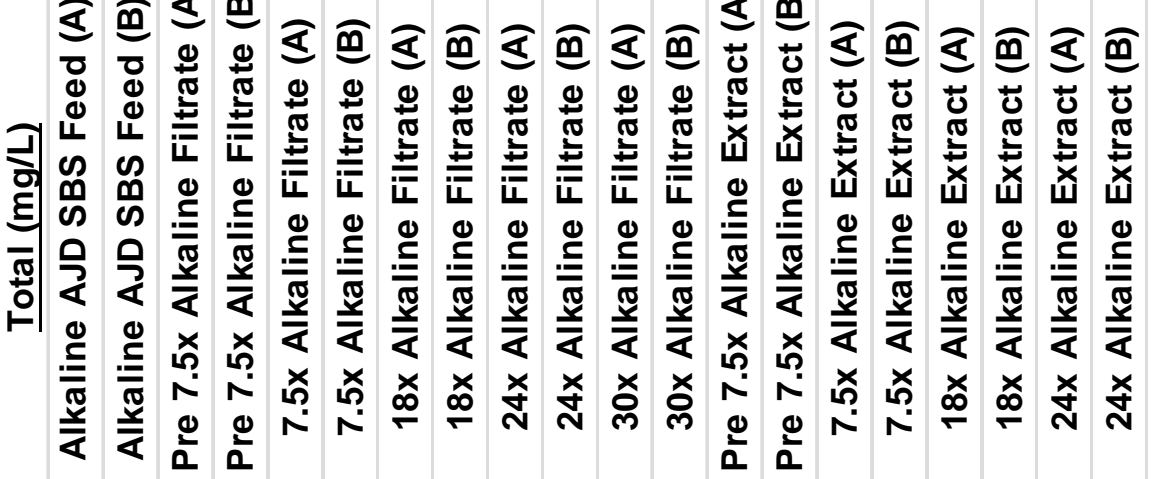


Table B-4 continued. Elemental and anion analysis for alkaline $\mathrm{pH}$ evaporation campaign (initial feed control samples, filtered evaporator pot samples, dissolved solid extract samples)

\begin{tabular}{|c|c|c|c|c|c|c|c|c|c|c|c|c|c|c|}
\hline$\grave{N}$ & $\begin{array}{l}8 \\
\text { ọ } \\
0 \\
v\end{array}$ & 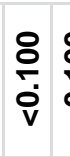 & ì & 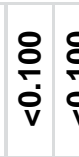 & & 5 & & 7 & & & & & & i. \\
\hline $\mathfrak{N |}$ & เి & 굼 & & 过 & b্g & & & \& & & 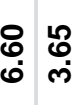 & \begin{tabular}{l}
$\tilde{\infty}$ \\
\hdashline \\
0
\end{tabular} & $\begin{array}{c}\hat{\sigma} \\
\text { O }\end{array}$ & & \\
\hline$\vec{F}$ & $\begin{array}{l}\stackrel{8}{a} \\
\dot{i}\end{array}$ & $\begin{array}{l}8 \\
\dot{v} \\
\dot{v}\end{array}$ & $\stackrel{8}{\stackrel{8}{v}}$ & $\begin{array}{l}8 \\
\dot{\vec{v}} \\
\dot{v}\end{array}$ & 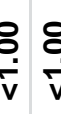 & $\underset{i}{i}$ & $\underset{i}{R}$ & 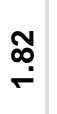 & & $\begin{array}{l}\stackrel{8}{\circ} \\
\dot{\mathrm{v}} \\
\overrightarrow{\mathrm{v}}\end{array}$ & $\begin{array}{l}\stackrel{8}{ } \\
\dot{\vec{v}}\end{array}$ & & & \\
\hline (n) & $\begin{array}{l}8 \\
\stackrel{8}{j}\end{array}$ & $\begin{array}{l}8 \\
\dot{\varphi} \\
\dot{v}\end{array}$ & 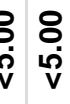 & 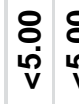 & 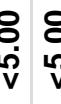 & 8 & $\begin{array}{l}8 \\
\dot{\rho} \\
\text { v }\end{array}$ & $\begin{array}{l}8 \\
\stackrel{\leftrightarrow}{\circ} \\
v\end{array}$ & & 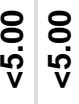 & 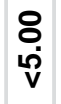 & & & 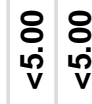 \\
\hline '̄| & $\hat{\mathrm{o}}$ & ठ & 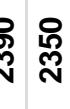 & 옹 & & & & : & & ֶָ户 & ஜُ & స్తું & & \\
\hline (s) & 总 & $\mathfrak{N}$ & 狩 & 离 & 总 & & ö & 今. & & : & $\underset{\infty}{\vec{X}}$ & ¿̊. & & 。্్త్ర \\
\hline a) & $\begin{array}{l}0 \\
\dot{\theta} \\
\dot{v}\end{array}$ & $\begin{array}{l}0 \\
\dot{\vec{v}} \\
\mathrm{v}\end{array}$ & مُ & 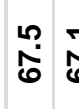 & تُ & & 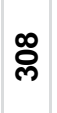 & $\vec{m}$ & & 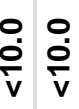 & $\begin{array}{l}\text { Dे } \\
\dot{\vec{v}}\end{array}$ & & & \\
\hline$\overline{\mathbf{z}} \mid$ & $\begin{array}{l}0 \\
\stackrel{9}{0} \\
\dot{0}\end{array}$ & \begin{tabular}{l}
0 \\
\multirow{a}{1}{} \\
v
\end{tabular} & : & \begin{tabular}{l}
8 \\
\multirow{7}{1}{} \\
$\dot{0}$ \\
$\mathrm{v}$
\end{tabular} & : & i & & ָ̃ & & 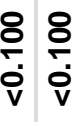 & $\begin{array}{l}8 \\
\stackrel{7}{1} \\
\dot{v}\end{array}$ & & & @ò \\
\hline$\frac{\pi}{2}$ & 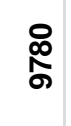 & 员 & 蛋 & $\begin{array}{l}\stackrel{8}{0} \\
\text { di }\end{array}$ & & & & & & ఫ્తి & & & & 。్ల \\
\hline 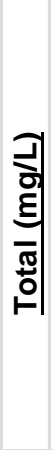 & 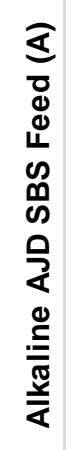 & 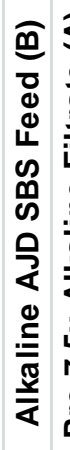 & 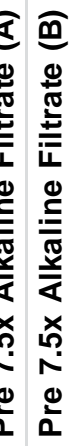 & 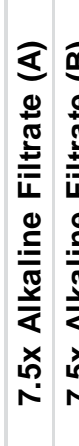 & 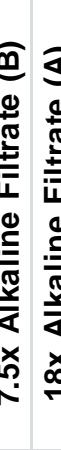 & 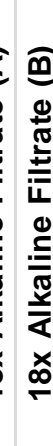 & 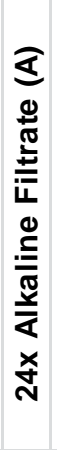 & 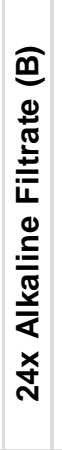 & 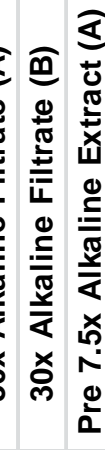 & 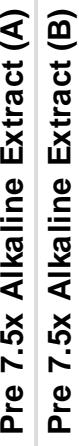 & 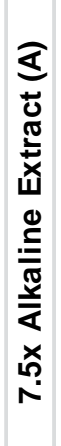 & 芴 & & 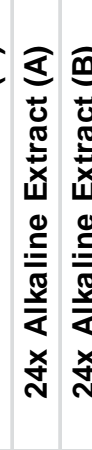 \\
\hline
\end{tabular}


Table B-4 continued. Elemental and anion analysis for alkaline $\mathrm{pH}$ evaporation campaign (initial feed control samples, filtered evaporator pot samples, dissolved solid extract samples)

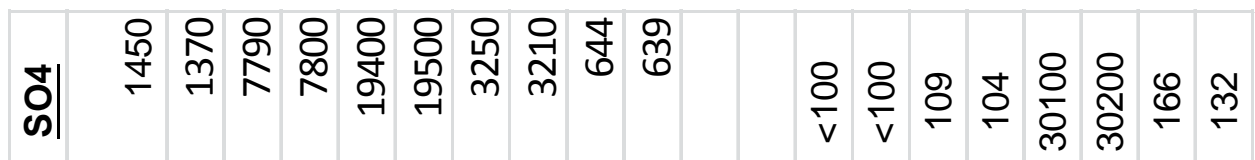

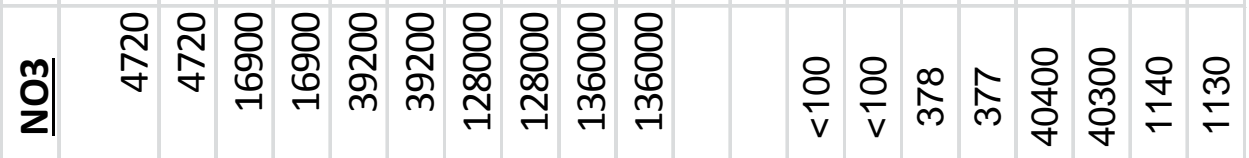

$$
\begin{aligned}
& \text { रे| }
\end{aligned}
$$

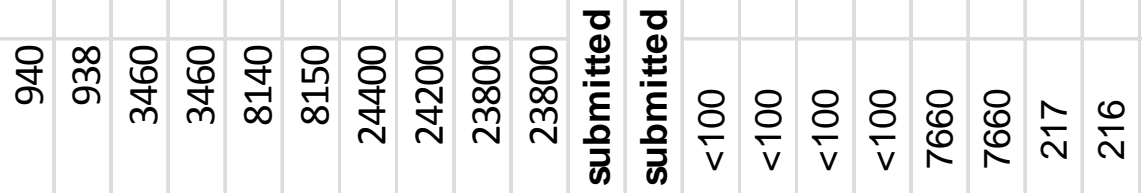

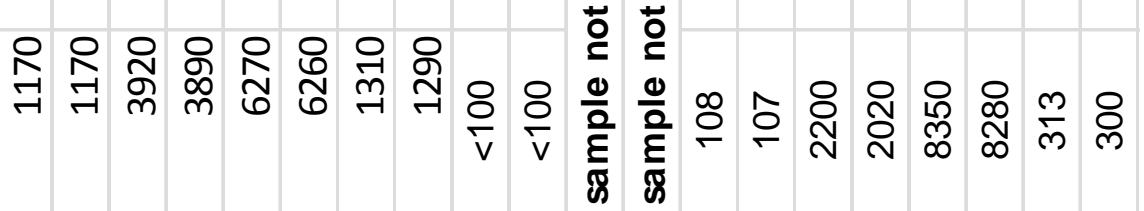

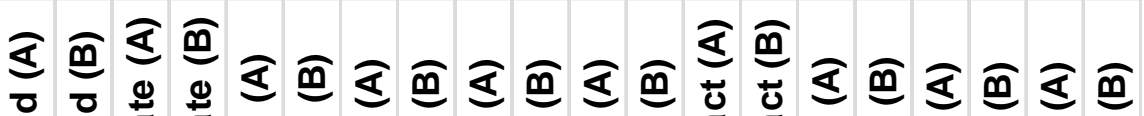

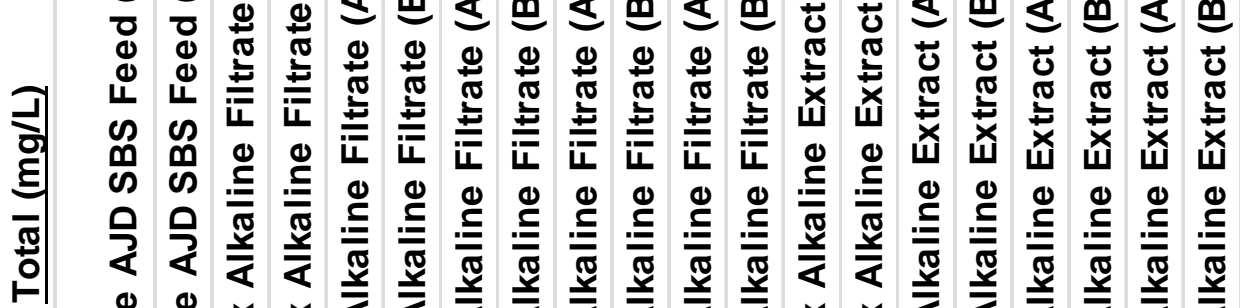

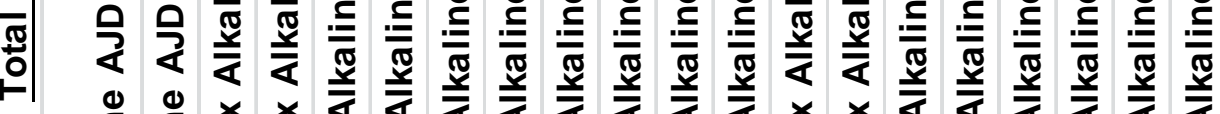

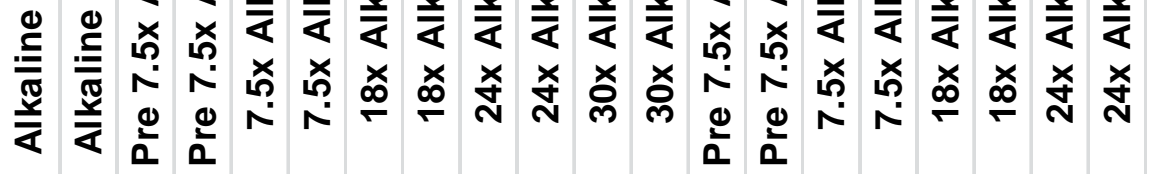

